\title{
INVESTING AND HEDGING TECHNIQUES IN THE CONVERTIBLE BOND MARKET
}

\section{APPROVED:}

Graduate Committee:
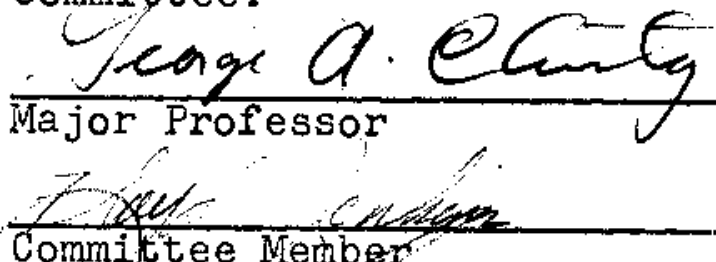

Commitee Member

Comen $d$ Prane

Committee, Member

$2 \operatorname{ten} 1 / 1$.

Committee Member

Dean of the school of esel

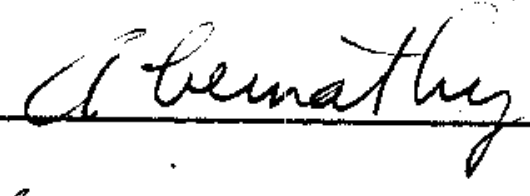

Dean of the School of Business Administration

Potrevab. I venlareat

Dean of the Graduate School 


\title{
INVESTING AND HEDGING TECHNIQUES IN THE CONVERTIBLE BOND MARKET
}

\section{DISSERTATION}

\author{
Presented to the Graduate Council of the \\ North Texas State University in Partial \\ Fulfillment of the Requiremerts
}

For the Degree of DOCTOR OF PHILOSOPHY By

Charles E. Vinson, M. B. A. Denton, Texas June, 1969 
TABLE OF CONTENTS

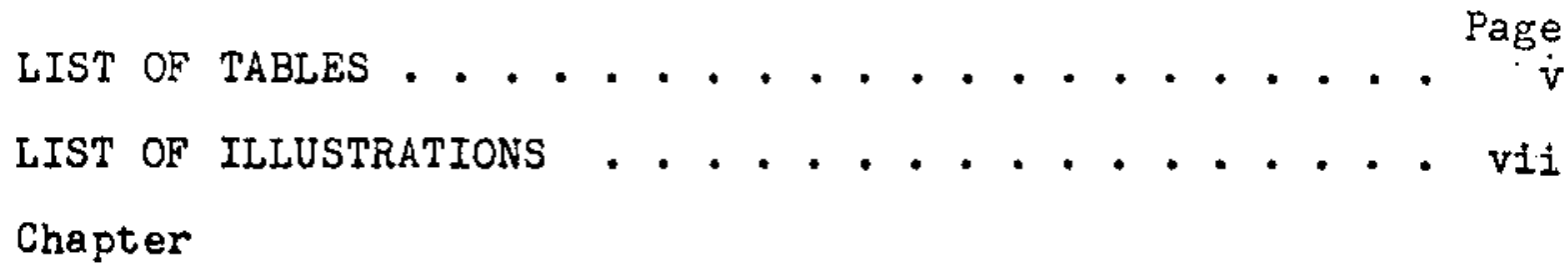

I. INTRODUCTION . . . . . . . . . . . 1

Basic Assumptions ............... . 2

The Major Hypotheses, Basic Methodology, and

the Investment and Hedging Techniques . . . 9

Risk and Market Imperfections . . . . . . 14

Key Definitions . . . . . . . . . . . 17

II. THE CONVERTIBLE BOND MARKET . . . . . . . . . . 20

The Historical Volume and Popularity of

Convertibles ................ 21

Characteristics of Convertibies and the

Issuing Companies . . . . . . . . . . 26

Motives Underlying Issuance of Convertibles . . 53

Institutional Investors . . . . . . . . . 65

Special Types of Convertibies........ . 76

Are Convertibles an Injustice to Existing

Stockholders?................. 79

Surmary .. . . . . . . . . . . . . . 83

III. DIRECT COMMITMENTS IN CONVERTIBLES . . . . . 87

How to Analyze Convertibles . . . . . . . 89

Rates of Return in a Buy-and-Hold Strategy . . 92

Selective Strategles . . . . . . . . . 107

Trading Strategies . . . . . . . . . . 115

Summary and Conclusions... . . . . . . . 124

IV. IMPERFECTION IN THE PRIMARY CONVERTIBLE BOND

MARKET . . . . . . . . . . . 128

The Marketing System for New Convertible

Issues ............... 129

Empirical Evidence of Primary Market Underpricing . . . . . . . . . . . 148

An Explanatory Theory .......... 165

Summary and Conclusions......... . 177 
V. THE PARTIAL HEDGE ................ 180

Problems in the Partial Hedge........ 181

Developing the Equations ........ 187

Applying the Equations .......... 204

Results of the Application ......... 212

Refining the Technique .......... 217

Conclusion .............. 225

VI. THE FULL HEDGE . . . . . . . . . . 226

Developing the Equations ........ 229

Should an Adjustment be Made for Upward Bias

in the Stock Market? .......... 238

Applying the Equations .......... 241

Results of the Application ........ 243

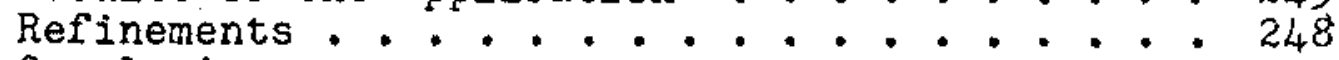

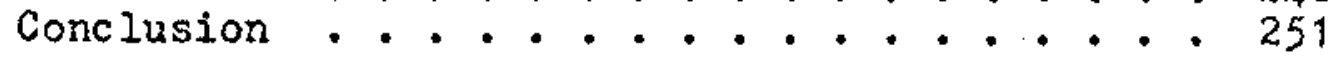

VII. SUMMARY OF FINDINGS . . . . . . . . 253

The Primary Convertible Market ....... 253

The Secondary Convertible Market :.:.:254

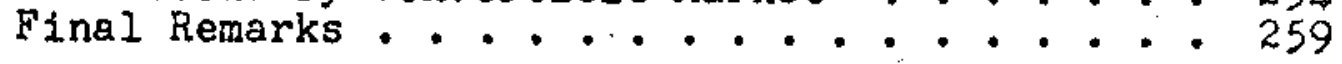

APPENDIX . . . . . . . . . . . . . 261

BIBLIOGRAPHY . . . . . . . . . . . 266 


\section{IIST OF TABLES}

Table

Page

I. Annual Dollar Volume of New Bond Issies, $1900-$ 1967, With Convertibles as Percentages of

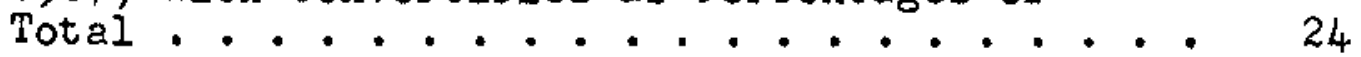

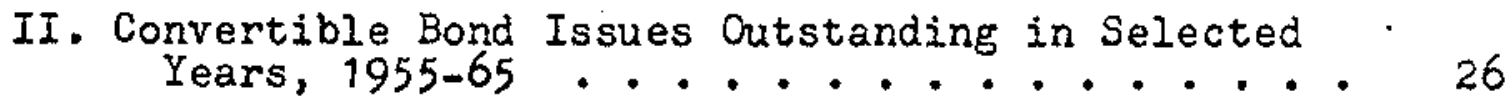

III. Average Size of Bonds Issued in Selected Time

Periods, 1937-52 ............. 28

IV. Average Size of Convertibles Issued in Selected

Time Periods, 1937-68, in Current Prices . . 29

V. Moody's Ratings of the Convertibles in the

Twenty-nine and Eighty-issue Samples . . . . 42

VI. Percentages of New Bond Issues With Moody's Ratings Below Baa, 1944-65 ........ 43

VII. Default Rates on Convertible and Nonconvertible Bonds, 1900-43............... 45

VIII. Earnings-Coverages on Convertible and Nonconvertible Bonds in Selected Periods, 1945-65 50

IX. Annual Net Purchases of Corporate Stocks and Bonds by Individuals and Financial Institu-

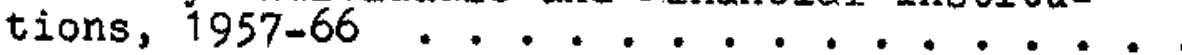

X. Institutional and Individual Purchases of New Corporate Debt Issues, Convertibles and All Bonds, January-March, 1962, as Percentages of Total ..............

XI. Rates of Return on Seventy-seven-Issue Sample of Listed Convertibles and Matching Stocks, 1956-68, With Comparable Fisher and Lorie Rates on AIl Common Stocks Iisted on the New York Stock Exchange .......... 
Table

XII. Highest-Profit and Average-Price hleasures Applied to Subgroups in the Seventy-sevenIssue Sample of Listed Convertibles. . . . 110

XIII. Results of Trading Strategy \#1. . . . . . . 116

XIV, Results of Trading Strategy \#3. . . . . . . 122

XV. Total Secondary Trading Volume on Sixty-four Convertibles at Selected Time Points . . . 154

XVI. Number of Days from Offering Date to First Secondary Market Transaction, Seventy-seven Convertibles .............

XVII. Summary of Underpricing Measures Based on Forty-three Rights offerings and Thirty-four Straight Offerings

XVIII. Raw and Annual Rates of Return Resulting from Purchase of Convertibles at Offering Price and Subsequent Sale in Secondary Market ..

XIX. All Partial Hedge Transactions Completed Under the Target Rule . . . . . . . .

XX. All Partial Hedge Transactions Completed Under the Filter Rule . . . . . . . . 214

XXI. Size Distribution of Gains and Losses, AII Completed Partial Hedge Transactions . . . 216

XXII. Selected partial Hedge Transactions Completed Under the Filter Rule......... 218

XXIII. Summary of Rates of Return on the Partial Hedge 223

XXIV. All Full Hedge Transactions Completed Under the Target Rule . . . . . . . . . 244

XXV. All Full Hedge Transactions Completed Under the Filter Rule.......... 2 245

XXVI. Size Distribution of Gains and Losses, A11 Completed Full Hedge Transactions . . . . 247

XXVII. Selected Full Hedge Transactions Completed Under the Target Rule......... . 249

XXVIII. Summary of Rates of Return on the Full Hedge . 250 


\section{IIST OF ILLUSTRATIONS}

Figure

Page

1. Index of Speculative Premiums ("First Dimension")

2. Hypothetical Demand Curve for New Convertible Bond ...................... 166

3. Curve of Speculative Premiums ("Second Dimension") 209 


\section{CHAPTER I}

\section{INTRODUCTION}

In dollar terms, the convertible bond market is larger today than ever in its history. In the primary market, the record 1967 volume of nearly $\$ 4.5$ biliion will be approximately equalled in 1968; this compares with an annual average of $\$ 836$ million during the ten preceding years. 1 In the secondary market, well over half of the New York Stock Exchange bond volume is accounted for by convertibles. There are approximately 140 convertible bond issues on that exchange, plus approximately 400 in other secondary markets, primarily overthe-counter; in comparison, there were fewer than 60 issues of any significant size in all secondary markets in 1955 and fewer than 200 in 1959.2 Much has been written on convertibles over the years, of course, but the bulk of this material represents "surface knowledge." There have been few in-depth studies of the convertible bond market in recent decades, resulting in serious gaps in the accumulated knowledge in the field. The purpose of this dissertation is to help remedy

\section{${ }^{1}$ See Table 1, p. 24 .}

2Recent data taken from Kalb, Voorhis and Co., Convertible Fact Finder (New York, April, 1968) and from The Wall Street Journal, Vol. XII (April 2, 1968), 23. Estimates for 1955 and 1959 from, "Two Way hedge, With Pitfalls," Business Week (Oct. 3, 1959), 115-16. 
that deficiency. Specifically, the study was designed to yield three types of information: (1) The degree of perfection prevailing in the parimary and secondary convertible bond markets; (2) the profit potential of various investing and hedging techniques in the convertible bond market; and (3) a judgment on whether each technique can be classified as rational or irrational.

Easic Assumptions

One of the basic assumptions throughout this dissertation is that differences in expected rates of return among different types of securities, or among different investment techniques within one type of security, can be accounted for by (1) imperfections in the market(s) and/or (2) compensation for expected additional risk. Furthermore, in a perfect security market, the actual realized net return on investment -after netting against gains the losses associated with risk elements--will be the same on any rational investment technique applied to a single type of security, and will differ among types of securities only to the extent that risk-averting investors concentrate commitments on one type of security while risk-seeking investors concentrate on another. It is assumed here that risk-averting investors will both expect and be satisfied with a lower net realized return than riskseeking investors. That is, expected return and expected utility are not synonymous concepts, nor are actual return and actual utility. Furthermore, variations in utility should 
not be dismissed simply as a form of market imperfection on the grounds that they denote irrational behavior on the part of investors. Differences in utility are legitimate, and they help explain observed differences in rates of return in the security markets. In a perfect security market, they would explain all of the differences.

Some symbolic representations may add concreteness to these basic assumptions. Considering any one investment alternative--say a common stock--and letting $R$ equal the expected or actual dollar return in a given future time period, letting $d$ represent the discount rate implicitly or explicitly used by an investor, and $V$ the (subjective) present value of the stock to the investor, then:

$$
V=\frac{R_{1}}{(1+d)}+\frac{R_{2}}{(1+d)^{2}}+\frac{R_{a}}{(1+d)^{3}}+\cdots+\frac{R_{t}}{(1+d)^{t}}
$$

such that $R_{1}, R_{2}, R_{3}, \ldots R_{t}$ represent the dollar returns in successive time periods through t time periods. The investor referred to here is the marginal investor whose actions determine the market price of the security.

The discount rate, $d$, can be thought of as being composed of two additive parts, a discount rate for time, which will be labeled $i$, and a discount rate for expected risk, which will be jabeled $r$. That is, $d=i+r$. The time rate, $i$, will not vary with the type of security involved, but the risk rate, $r$, will vary depending upon the investor's assessment of the risk involved in the commitment. Conceptually, the 
risk rate, $r$, would be equal to the product of two factors-a factor representing the expected variability of dollar return about the expected mean return, $R$; and a factor representing the marginal investor's personal sensitivity to risk (that is, a factor denoting whether he is, relatively, a risk-seeking or a risk-averting investor). If the first of these two factors is taken to be the standard deviation, $\sigma$, of the array of returns about the mean return, $R$, and if the second factor is labeled $\alpha$, then $r=a \sigma$. The a factor is a "coefficient of utility" that varies indirectly with the investor's willingness to accept risk. With these modifications:

$$
V=\frac{R_{1}}{\left(1+i+r_{1}\right)}+\frac{R_{2}}{\left(1+i+r_{2}\right)^{2}}+\frac{R_{3}}{\left(1+i+r_{3}\right)^{3}}+\cdots+\frac{R_{t}}{\left(1+i+r_{t}\right)^{t}}
$$

And:

$$
V=\frac{R_{1}}{\left(1+i+a_{1} \sigma_{1}\right)}+\frac{R_{2}}{\left(1+i+a_{2} \sigma_{2}\right)^{2}}+\frac{R_{3}}{\left(1+i+a_{3} \sigma_{3}\right)^{3}}+\cdots+\frac{R_{t}}{\left(1+i+a_{t} \sigma_{t}\right)^{t}}
$$

Or:

$$
V=\sum_{t=1}^{n} \frac{R_{t}}{\left(1+i+a_{t} \sigma_{t}\right)^{t}}
$$

Or, if there is no stated limit to the number of time periods:

$$
V=\sum_{t=1}^{\infty} \frac{R_{t}}{\left(1+i+a_{t} \sigma_{t}\right)^{t}}
$$

The basic assumption is that, in a perfect market, the time discount rate, $i$, for this investment alternative will be the same as the time discount rate for all other investment alternatives. Any difference in rate of return between two 
or more alternative investments is attributable to differences in the risk rate, $r$.

It is not possible to solve for $i$ in terms of $V, R$, $a$, and $\sigma$ in the general equation immediately above. However, a solution for $i$ can be obtained by making some simplifying assumptions. Instead of assuming that $R$ may vary from time period to time period in a random fashion, assume that $R$ grows at a constant rate, starting with some initial return, $R_{0}$, with the symbol $g$ used to designate the growth rate per time period. It may also be assumed that the investor's risk rate is constant through successive time periods. Then:

$$
V=\sum_{t=0}^{\infty} \frac{R_{0}(1+g)^{t}}{(1+i+r)^{t}}=R_{0} \sum_{t=0}^{\infty}\left(\frac{1+g}{1+i+r}\right)^{t}
$$

assuming no necessary time limit short of infinity.

Thus, assuming $(i+r)>g$ :

$$
\begin{aligned}
& V=R_{0} \int_{0}^{\infty}\left(\frac{1+g}{1+i+r}\right)^{t} d t \\
& V=\lim _{k \rightarrow \infty} R_{0} \int_{0}^{k}\left(\frac{1+g}{1+i+r}\right)^{t} d t \\
& V=\lim _{k \rightarrow \infty} R_{0}\left[\left(\frac{1+g}{1+i+r}\right)^{t} \frac{1}{\ln e\left(\frac{1+g}{1+i+r}\right)}\right]_{t=0}^{t=k} \\
& V=\lim _{k \rightarrow \infty} R_{0}\left[\left(\frac{1+g}{1+i+r}\right)^{k} \frac{1}{\ln e\left(\frac{1+g}{1+i+r}\right)}-\left(\frac{1+g}{1+i+r}\right)^{0} \frac{1}{\ln \left(\frac{1+g}{1+i+r}\right)}\right] \\
& V=R_{0}\left[\frac{-1}{\ln e\left(\frac{1+g}{1+i+r}\right)}\right]
\end{aligned}
$$


6

$$
\begin{aligned}
\frac{-R_{0}}{V} & =\ln _{e}\left(\frac{1+g}{1+i+r}\right) \\
e^{\left(\frac{R_{0}}{V}\right)} & =\frac{1+g}{1+i+r} \\
i & =\left[\frac{1+g}{\left.e^{\left(\frac{-R_{0}}{V}\right)}\right]-r-1}\right. \\
i & =e^{\left(\frac{R_{0}}{V}\right)}(1+g)-r-1
\end{aligned}
$$

This equation still refers only to one investment alternative. Adding a subscript to identify various other alternative investments:

$$
\begin{aligned}
& i_{1}=e^{\left(\frac{R_{0}}{V}\right)_{1}}\left(1+g_{1}\right)-r_{1}-1 \\
& i_{2}=e^{\left(\frac{R_{0}}{V}\right)_{2}\left(1+g_{2}\right)-r_{2}-1} \\
& i_{3}=e^{\left(\frac{R_{0}}{V}\right)_{3}}\left(1+g_{3}\right)-r_{3}-1 \\
& \dot{1}_{p}=e^{\left(\frac{R_{0}}{V}\right)_{p}\left(1+g_{p}\right)-r_{p}-1}
\end{aligned}
$$

where $1,2,3, \ldots$ denote various alternative investments.

The basic assumption, then, is that in a perfect

market: 
Or:

$$
\begin{aligned}
{\left[e^{\left(\frac{R_{0}}{V}\right)_{1}}\left(1+g_{1}\right)-r_{1}\right] } & =\left[e^{\left.\left(\frac{R_{0}}{V}\right)_{2}\left(1+g_{2}\right)-r_{2}\right]=\left[e^{\left(\frac{R_{0}}{V}\right)_{3}}\left(1+g_{3}\right)-r_{3}\right]}\right. \\
& =\cdot \cdot=\left[e^{\left(\frac{R_{0}}{V}\right)_{p}}\left(1+g_{p}\right)-r_{p}\right]
\end{aligned}
$$

In a perfect market, not only would the time rate, $i$, be equal among all alternative investments, but $V$ (labeled with the proper subscripts) would be the market price of each investment as well as the subjective present value assigned to such investments by marginal investors. Hence, the expected and actual rate of return on a particular investment would be the marginal investor's time discount rate (constant among all alternative investments) plus his risk rate (variable among different investment alternatives of unequal risk). Risk-averting investors--those with a large risk rate stemming from a large a factor--will assign small present values to risky investments, leaving such investments for their risk-seeking cousins and concentrating their commitments, instead, in less profitable but less risky investments. Within one type of security--that is, within one risk category--expected and realized rates of return produced by the application of different rational investment technioues would be equal in a perfect market. ${ }^{3}$

3 The interest rate concept on which this approach is based bears some resemblance to the analysis by John $R$. Hicks in his Value and Capital (Oxford, 1939), pp. 161-170. 
It should be noted that $R_{0}$ (or $R$ in the original formulation) denotes both expected mean-average return and actual return in a perfect market. It is perhaps expecting too much of a perfect market to insist that investors have perfect advance knowledge of the future, and a strong case could be built for allowing differences between at least rational expected average returns and actual subsequent returns, without declaring the market to be imperfect. It is suggested, however, that the term "efficient market" be reserved for a market that falls short of a "perfect market" because of an inability to predict future dollar returns on alternative investments, and that the latter term continue to be used to designate a market that is perfect in the full sense. The distinction is not critical as far as this dissertation is concerned. And, in any case, much of the conceptual difference between a "perfect market" and an "efficient market" disappears as one moves from the level of individual securities to groups or types of securities, and as one moves from short time periods to long time periods. The dissertation is largely concerned with convertibles as a group or type of security relative to other types of securities, an exception being one part of Chapter III dealing with subgroups of convertibles. And the dissertation is concerned mainiy with rates of return over relatively long time spans.A frequently used phrase in the dissertation is "nearly for highly) perfect market," which can be taken as roughly synonymous to "efficient market." 
The Major Hypotheses, Basic Methodology, and the Investment and Hedging Techniques

Two separate and distinct hypotheses guided the investigations presented in the following chapters. First, it was hypothesized that the secondary convertible bond market is a nearly perfect market both internally and relative to other security markets, the stock and straight bond markets being the main reference points in the latter case. That is, it was hypothesized that, after making allowances for the utility phenomenon described above, average realized rates of return resulting from ordinary "buy-and-hold" commitments in convertibles would approximately equal those resulting from comparable commitments in the stock and straight bond markets. And it was further hypothesized that altemative rational investment or hedging techniques applied internally within the convertible bond market would produce approximately equal returns. (A brief description of the techniques appears below,) Completely positive results in the testing of this secondary market hypothesis were not expected. One of the main objectives was to single out any investment or hedging technique that produced above-average returns by virtue of its capacity to pinpoint and take advantage of any imperfections in the secondary market. Investigations preceding the formal study, however, led to the conviction that the imperfections in the secondary convertible market were relatively minor. In contrast, it was hypothesized that the primary convertible bond market is a seriously imperfect market in which 
original issue prices tend to be chronically below prices prevailing in initial secondary trading. There are two implications to this hypothesis. One is the possibility of above-average profit for a speculator able to bridge the gap between the primary and secondary market. The other is that, if the hypothesized imperfection does in fact exist, real (as well as monetary) resources are failing to flow in an efficient manner from savers to producers.

The basic approach in the testing of these hypotheses was to start with the secondary market hypothesis and, if a reasonably high degree of perfection was in fact found in that market, to use the secondary market as a basis for measuring the degree of perfection prevailing in the primary convertible market. A high degree of perfection in the secondary convertible market would be confirmed if (1) average realized rates of return generated by direct buy-and-hold commitments in convertibles differed from average rates of return on direct commitments in common stocks and in straight bonds by amounts explainable largely in terms of known differences in risk among the three types of securities. That is, in a perfect market, one would expect to find a structure of realized rates showing the highest rates on stocks, the lowest rates on straight bonds, and with convertible rates in between. And (2) if average realized rates of return among various investment techniques applied internally within the convertible bond market produced equal returns. As disclosed in Chapter III 
of the dissertation, the first of these two criteria was. largely met. A moderate degree of imperfection was uncovered by application of the second criterion. Overall, however, the secondary convertible market was deemed to be sufficiently perfect to serve as a starting point for measurement of the degree of perfection existing in the primary market, the subject of Chapter IV. The basic procedure here was to examine (after some carefully defined adjustments) the differences between new-issue prices in the primary market and prices prevailing in initial secondary treding. A persistent tendency for new-issue prices to change in an upward direction in initial secondary trading was taken as evidence of imperfection in the primary market--that is, evidence of the ability to obtain rates of return greater than could be accountea for by the risk/utility phenomenon.

In the secondary market study, the comparison with the stock market was made by comparing the realized buy-and-hold rate of return on convertibles with a comparable rate for listed common stocks computed by Lawrence Fisher and James H. Lorie.4 A less rigorous comparison was also made with average rates on stocks reported by other authors, and with average rates on straight debt issues. These comparisons

4Lawrence Fisher and James H. Lorie, "Rates of Return on Investments in Common Stocks, the Year-by-Year Record, 19261965," reprint, supplied by Merrill Lynch, Pierce, Fenner and Smith, Inc., of article scheduled to appear in the July, 1968,
Journal of Business, Vol. Xxxx. 
are presented in Chapter III. Internally, within the convertible bond market, the buy-and-hold rate was compared with the rates resulting from the application of various other investment and hedging techniques. Specifically, the latter half of Chapter III is devoted to the computation of rates of return generated by selective, as distinct from nonselective or random, direct commitments in the secondary convertible bond market, and to the rates of return Eenerated by three different short-term trading techniques. (In a perfect market, random selections would produce the same-rates of return as selective commitments, and short-term rates of return would be the same as long-term buy-and-hold rates of return.)

In Chapter $V$, a combination internal/external technique is explored--the partial hedge. The partial hedge is a technique involving the purchase of a convertible and the simultaneous short sale of approximately one-half the number of shares of common stock into which the bond is convertible. The exact number of shares sold short is a crucial variable; decision rules for the determination of this variable were developed in the study. In an ideal partial hedge situation, a profit is earned regardless of which direction the common stock price subsequentiy moves.

In Chapter VI, a superficially similar but conceptually distinct technique, the full hedge, is investigated. The full hedge involved a simultaneous short sale of approximately 
the full number of shares into which the bond is convertible. As in the partial hedge, models were devised to make decisions regarding the exact number of shares sold short, plus other decisions vital to rational operation of the technique.

By comparing the rate of return generated by the partial and fuIl hedges with other rates computed in the dissertation, additional light was thrown on the degree of perfection in the security markets.

As mentioned earlier, the dissertation was designed to yield three distinct types of information. In addition to conclusions regarding the degree of perfection in the primary and secondary convertible bond markets, and the average rates of return obtainable through the use of various investment and hedging techniques in these markets, judgments would also be formed on the rationality of the investment and hedging technioues themselves. In a perfect market, a rational investment technique will produce only a "normal" return. Below-normal returns in a perfect market denote an irrational technioue. Above-normal returns would indicate a rational technique in an imperfect market. Conclusions regarding all three types of information-market perfection, rates of return, and rationality of the investment and hedging techniques-are presented in Chapter VII, which summarizes the findings of the dissertation.

Although there is an active over-the-counter market. for convertibles, the present study is restricted largely to the 
market for listed convertioles (and, in the external comparisons, to the market for listed stocks). With a few rare exceptions, this automatically restricted the study to convertibles listed on the New York Stock Exchange, since there are very few convertibles on the American Stock Exchange (only two at mid-July, 1968)5 or on the regional exchanges (none at mid-July, 1968).6 Whether the findings of the present study can be generalized to apply to the over-thecounter market is an open question; certainly, one should not do so without reservations.

\section{Risk and Market Imperfections}

Since risk and market imperfections are key concepts in the dissertation, a brief delineation of the nature of each will add clarity to the probings of the following chapters. Investors face five types of risk:

1. Business risk. This is the risk of shrinkage in earnings or earnings growth because of one or more business problems--incompetent mamagement, problems in the industry, general economic recession, etc. Both investment income and market value can be affected, the latter because of the inclination of the investment community to establish market price on the basis of current or anticipated earnings.

5 The WalI Street Journal, XIII (JuIy 15, 1968), 18. 6Ibid., p. 19. 
2. Market risk. This refers to the risk of fluctuations in the stock and convertible bond markets steming from causes other than actual changes in earnings. Business risk is releted to so-called "fundamental factors," while market risk is related to so-called "technical factors." Maxket risk can be thought of as a decline in price/earnings ratios when earnings are held constant. There is, obviously, a corresponding opportunity for gain.

3. Interest-rate risk. This is the risk of decline in values of fixed-income securities (preferred stocks, regular bonds, and convertibles when the conversion feature is not operative) caused by a rise in generally prevailing interest rates. There is, of course, a corresponding opportunity for profit when interest rates decline.

4. Risk of variability of return. This refers to the inability of many individual investors to utilize the law of large numbers in situations involving variability in a probability distribution--that is, the inability to net losses on one investment against gains on another, or an inability to net temporary losses against longer-term gains. Stated very simply, small investors cannot properly diversify, and they lack the financial stability required to survive temporary setbacks. Hence, the demand a premium in expected return as compensation for the additional risk.7 This type of market imperfection rather than as a risk element, on 
risk element overlaps, in a sense, the first three described above.

5. Inflation risk. This is the risk of loss of purchasing power via holding of assets that earn less than the rate of inflation. In general, business, market, and interest-rate risks vary inversely with profit potential. Hence, investors are motivated to assume greater risks of these types in ar effort to diminish the risk of inflation loss. Furthermore, there is interaction between interest-rate risk and inflation risk. To the extent that buyers of fixed-income securities expect future inflation, they will demand a compensating increase in yield-to-maturity; if enough investors share this expectation, interest rates will rise, thereby depressing prices of fixed-income securities.

Risk can be thought of, conceptually, as existing separately from an investor's perception of it, although it may not be possible to measure risk in practice without reference to subjective assessment of risk. Irrational assessment of risk, or a rational but inaccurate assessment of risk, can be conveniently lumped in the category of market

the grounds that the problems faced by the small investor would be solved by some means in a perfect market, and on the grounds that variations in return among individual securities are caused in the first place by imperfect allocation of funds on the part of investors. Classifying variability of return as a risk element, however, is more consistent with the definition implicitly or explicitly existing in most of the literature. For example, see Jack Hirshleifer, "Risk, the Discount Rate, and Investment Decisions, "American Economic Review, LI (May, 1961), 112-20 
imperfections as discussed below.

Major sources of market imperfection include the following:

1. Inability to accurately gauge risk.

2. Irrational behavior on the part of investors.

3. Lack of knowledge or inefficient communications.

4. Geographical barriers.

5. Custom or habit.

6. Institutional rigidities.

7. Market manipulation.

8. Market management (for example, the Federal Reserve mergin roquirement, or pricing practices in the primary market).

9. Tax factors ("locked-in" positions, tax-free municipal bond interest, etc.).

\section{Key Definitions}

In addition to this definition of risk elements and sources of market imperfection, there are several key terms, the understanding of which is essential to a proper interpretation of the presentation to follow:

1. Current price of a convertible, or market price at some specified time, should always be taken to mean the market price of a $\$ 1000$-denomination bond. Some convertibles come in other denominations, but the $\$ 1000$ denomination will be uniformily assumed throughout the dissertation.

2. Matching stock, or convertible-matching stock--terms that will be reserved for the common stock into which a convertible bond is convertible. 
3. Intrinsic value of a convertible--sometimes called the "investment value" or the "theoretical value," meaning the price at which the bond would sell if the conversion feature were either nonexistent or else regarded as without value by the investing public. The intrinsic value, conceptually at least, changes only with shifts in general interest rates or in the credit-worthiness of the company.

4. Conversion value--the number of shares of stock into which the bond is convertible, multiplied by the current price (or price at a specified time), per share, of the matching stock.

5. Conversion price--in normal cases, conversion price is a dollar measure of the conversion feature. It is systematically related to the number of shares of common stock that an investor would receive upon conversion of the bond, as follows: Conversion price $=\frac{\$ 1000}{\text { Number of shares into }}$ which bond is convertible

6. Speculative premium--the excess of current market price of a convertible over either conversion value or intrinsic value, whichever of the latter two is highest. For example, if the conversion value is $\$ 1100$, the intrinsic value $\$ 1000$, and the current market price of the bond \$1250, a \$150 speculative premium exists. Or, if conversion value is $\$ 800$, the intrinsic value $\$ 1000$, and the current market price of the bond $\$ 1250$, a $\$ 250$ speculative premium exists. 
Speculative premiums are a very important influence in the convertible bond market. They exist for two main reasons. First, investors who are interested in nonmargined commitments in equities recognize the convertible as an alternative investment with downside protection. They will bid the market price of the convertible up to some compromise level providing less than complete downside protection. Secondly, until. recently at least, margin speculators used the convertible as a way around the Federal Reserve margin requirement, since the requirement was virtually inapplicable to bonds. In the past, banks have loaned as much as eighty or ninety per cent on convertible bond purchases. This caused a further bidding up of convertible prices and higher speculative premiums. This second cause of speculative premiums was partly, but not entirely, squelched by the enactment of a fifty per cent Federal Reserve margin requirement on convertible, effective March 11, 1968, with a subsequent increase to sixty per cent on June 8, 1968. Other factors have influenced the general level of speculatiwe premiums over the years. These factors are discussed at appropriate points in the dissertation. The following chapter, Chapter II, is a presentation of background material and findings or other researchers. It provides information and evaluations necessary for a full understanding of subsequent chapters. 


\section{CHAPTER II}

\section{THE CONVERTIBLE BOND MARKET}

The material in this chapter is mostly of a general. nature, dealing with various facets of the convertible bond market. There are four reasons for including such a chapter. First, to glean from the literature the end result of research conducted by others, and thus to avoid duplicating their efforts. Secondly, to compare and evaluate the findings of other scholars. Thirdly, to build up a broad, general understanding of the convertible bond market preparatory to the more intensive investigations of subsequent chapters. And, finally, to help define with precision the scope, limitations, and problems involved in the study underlying this dissertation.

The specific topics explored in this chapter include the historical volume and popularity of convertibles; the motives behind the issuance of convertibles by corporations; the characteristics or features of convertibles prevalent in the market and of the issuing corporations; some special types of convertibles that have been excluded from the study; a brief analysis of the charge that the sale of a convertible bond issue works an injustice on existing stockholders; and, finally, the increasing role of institutional investors in the convertible bond market. 
It will be recalled that one of the major hypotheses of this dissertation deals with the primary convertible bond market, while the other deals with the secondary market. Chapters following this one are divided accordingly. Such a division would be awkward for this chapter, however, and was not attempted.

The Historical Volume and Popularity of Convertibles

The history of convertibles has been investigated by several researchers, but probably most thoroughly by $C$. James Pilcher. ${ }^{1}$ Pilcher found that the first known use of a convertible occurred during the reign of King Charles I, 1600-1649.2 In the United States, evidence of convertibles appears in the financial literature of the first half of the eighteenth century. 3 Daniel Drew, Jay Gould, Commodore Vanderbilt, and others made liberal use of convertibles during the great era of expansion in the railroad industry in the nineteenth century. 4 In the first decade of the

1C. James Pilcher, Raising Capital With Convertible Securities (Ann Arbor, Michigan, 1955). Pilcher's study covers both convertible bonds and convertible preferred stock.

2 Arthur Dewing, Financial Policy of Corporations, p. 242, footnote 1 , cited in Pilcher, ibid., p. 2 .

3 W. Bayard Taylor, Financial Folicies of Business Enterprise, p. 292, cited in Pilcher, ibjd., p. 2 .

4Montgomery Rollins, "Convertible Bonds and Stocks," Anna 1s of American Academy of Political and Social Science, XXXV (No. 3, 1910), 99, cited by Pilcher, ibid., p. 3. Also, Canadian Convertible Debenture Issues, p. 1, cited in Pilcher, 
twentieth century, the use of convertibles to raise new capital spread to other types of companies; examples include American Telephone and Telegraph, Otis Elevator, Diamond Match Company, and Lackawanna Steel Company. 5 Numerous issues appeared during the time span from 1914 to 1924; some thirteen per cent of all corporate bonds issued during this period are reported to have been convertible. 6 A study covering both bonds and preferred stocks during the June, 1928, to January, 1929, period revealed that twenty-seven per cent of the new issues contained conversion features. 7 Some 27.4 per cent of the unsecured bonds and 7.8 per cent of the secured bonds issued during the $1937-40$ period were onvertible. ${ }^{8}$

Pilcher's research covering the 1933-52 period-including all new offerings in excess of $\$ 300,000$ each except equipment trust obligations-mrevealed that 182 of 1959, or 9.3 per cent, of the new publicly offered debt issues carried conversion features; in the category of private Dlacements, however, only 21 of 3914 bonds, of 0.5 per cent, contained conversion provisions. Filcher offers several

5Montgomery Rollins, Convertible Securities, pp. 94-98, cited in Pilcher, ibid., p. 3 .

6C. C. Keith, "Convertible Securities and Stock Purchase Warrants," Rocky Mountain Law Review, II (Nov., 1929), 16; cited in Pilcher, ibid., p. 3 .

7C. C. Keith, "Convertible Securities and Stock Purchase Warrants," p. 28, cited in Pilcher, ibid., pp. 3, 4.

8 Pilcher, ibid., p. 7 . 
reasons why the volume of convertibles was light in the private placements category: the prevalence of pre-emptive right provisions, which precluded the private placement of convertible bonds (or stocks) without a privileged-subscription offering; moral obligations on the part of the corporations; the frequency of private placement of debt instruments by closely-held companies wanting to avoid dilution of equity and voting power; and the emergence of life insurance companies --with their traditional preference for straight debt securities--as major recipients of private placements.9

In terms of dollar volume, rather than number of issues, the approximate year-by-year volume of new convertibles, both publicly and privately marketed in this century, is shown in Table I. It is obvious from the table that the popularity of convertibles has fluctuated widely over the years. There is some correlation between movements in the stock market and the volume of new convertibles, though the correlation is not high enough to adequately explain the erratic volume. (This relationship has been treated more thoroughly in the section of this chapter entitled "Motives Underlying Issuance of Convertibles," beginning on page 53.) Of particular interest are the peaks of 1929 and 1955, and the tremendous upsurge in 1965, 1966, and 1967. The recently enacted margin requirement on convertibles seems to have had 
TABLE I

ANNUAL DOLLAR VOLUME OF NEW BOND ISSUES, 1900-1967, WITH CONVERTIBLES AS

PERCENTAGE OF TOTAL

(Millions of Dollars)

\begin{tabular}{|c|c|c|c|c|c|c|c|}
\hline Year & $\begin{array}{c}\text { Al1 } \\
\text { Bonds }\end{array}$ & $\begin{array}{c}\text { Convert } \\
\text { ibles }\end{array}$ & $\begin{array}{l}\% \text { of } \\
\text { Total }\end{array}$ & Year & $\begin{array}{c}\text { AII } \\
\text { Bonds }\end{array}$ & $\begin{array}{c}\text { Convert- } \\
\text { ibles }\end{array}$ & $\begin{array}{l}\% \text { of } \\
\text { Total }\end{array}$ \\
\hline $\begin{array}{l}1900 \\
1901 \\
1902 \\
1903 \\
1904 \\
1905 \\
1906 \\
1907 \\
1908 \\
1909 \\
1910 \\
1911 \\
1912 \\
1913 \\
1914 \\
1915 \\
1916 \\
1917 \\
1918 \\
1919 \\
1920 \\
1921 \\
1922 \\
1923 \\
1924 \\
1925 \\
1926 \\
1927 \\
1928 \\
1929 \\
1930 \\
1931 \\
1932 \\
1933\end{array}$ & $\begin{array}{r}\$ 693.4 \\
1489.0 \\
1009.8 \\
919.2 \\
1092.0 \\
1226.0 \\
1092.0 \\
1089.3 \\
1112.1 \\
1264.0 \\
1133.2 \\
1299.5 \\
1396.9 \\
1167.6 \\
1193.4 \\
1184.8 \\
1485.0 \\
1228.6 \\
800.4 \\
1038.7 \\
1448.0 \\
2074.6 \\
2270.2 \\
2118.2 \\
2227.0 \\
2202.4 \\
2724.8 \\
3856.8 \\
2997.0 \\
1957.7 \\
2978.3 \\
2030.1 \\
873.7 \\
444.3\end{array}$ & $\begin{array}{r}11.2 \\
125.0 \\
65.6 \\
32.6 \\
33.1 \\
164.5 \\
184.3 \\
166.6 \\
106.5 \\
198.4 \\
123.5 \\
29.1 \\
74.3 \\
218.7 \\
75.3 \\
198.9 \\
193.5 \\
68.4 \\
111.2 \\
141.9 \\
275.0 \\
102.0 \\
148.1 \\
134.6 \\
79.4 \\
159.8 \\
186.4 \\
156.8 \\
294.3 \\
788.5 \\
570.4 \\
58.5 \\
30.6 \\
39.8\end{array}$ & $\begin{array}{c}1.6 \% \\
8.4 \\
6.5 \\
3.5 \\
3.0 \\
13.4 \\
16.9 \\
15.3 \\
9.6 \\
15.7 \\
10.9 \\
2.2 \\
5.3 \\
18.7 \\
6.3 \\
16.8 \\
13.0 \\
5.6 \\
13.9 \\
13.7 \\
19.0 \\
4.9 \\
6.5 \\
6.4 \\
3.6 \\
7.3 \\
6.8 \\
4.1 \\
9.8 \\
40.3 \\
19.2 \\
2.9 \\
3.5 \\
9.0 \\
\end{array}$ & $\begin{array}{l}1934 \\
1935 \\
1936 \\
1937 \\
1938 \\
1939 \\
1940 \\
1941 \\
1942 \\
1943 \\
1944 \\
1945 \\
1946 \\
1947 \\
1948 \\
1949 \\
1950 \\
1951 \\
1952 \\
1953 \\
1954 \\
1955 \\
1956 \\
1957 \\
1958 \\
1959 \\
1960 \\
1961 \\
1962 \\
1963 \\
1964 \\
1965 \\
1966 \\
1967\end{array}$ & 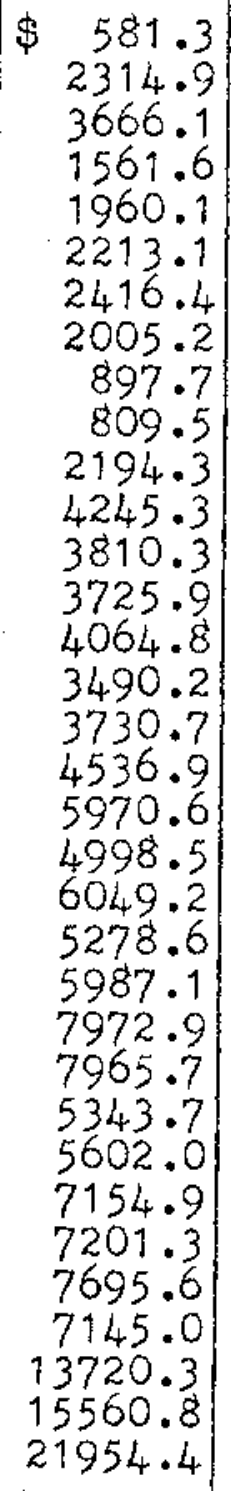 & $\begin{array}{r}129.1 \\
115.8 \\
142.7 \\
257.3 \\
218.9 \\
260.6 \\
11.5 \\
256.1 \\
46.3 \\
0.0 \\
34.2 \\
13.0 \\
401.9 \\
396.6 \\
230.4 \\
428.4 \\
122.6 \\
472.8 \\
908.9 \\
949.3 \\
133.9 \\
1412.1 \\
757.6 \\
1064.0 \\
1147.0 \\
628.0 \\
462.0 \\
704.0 \\
445.0 \\
348.0 \\
425.0 \\
1263.8 \\
1871.7 \\
4474.6\end{array}$ & $\begin{array}{c}22.2 \% \\
5.0 \\
3.9 \\
16.5 \\
11.2 \\
11.8 \\
0.5 \\
12.8 \\
5.2 \\
0.0 \\
1.6 \\
0.3 \\
10.5 \\
10.6 \\
5.7 \\
12.3 \\
3.3 \\
10.4 \\
15.2 \\
19.0 \\
2.2 \\
26.8 \\
12.7 \\
13.3 \\
14.4 \\
11.8 \\
8.2 \\
9.8 \\
6.2 \\
4.5 \\
5.9 \\
9.2 \\
12.0 \\
20.4 \\
10\end{array}$ \\
\hline
\end{tabular}

*Source: 1900-64 data from Thomas R. Atkinson, Trends in Corporate Bond Quality, p. 78, compiled from data developed by W. R. Hickman, by Moody's Investors Service, and by Investment Dealers' Digest. 1965-67 data from Securities and Exchange Commission, Statistical Bulletin, Feb., 1968 ,
p. 17 . 
no effect on this high rate of new-issue volume. Ashby Bladen, director of convertible bond research at Salomon Brothers and Hutzier, was quoted as predicting a total 1968 volume of $\$ 4$ billion; Frank S. Glaser of Merrill Lynch agrees that the volume will probably continue high into the near future. ${ }^{10}$ In view of the erratic record of the past, however, it would probably be unrealistic to forecast an indefinite continuation of the current volume.

In terms of the number and dollar volume of convertible issues outstanding--that is, traded on the secondary market-. a useful, though not entirely complete, tabulation for selected years from 1955 through 1965 is shown in Table II on the following page. This tabulation includes only the issues covered in the Moody's Mianuals--roughly two-thirds of the total number of convertible issues but a larger percentage of the aggregate dollar volume. As mentioned in Chapter I, there are currently over 500 issues outstanding. The volume of both new and secondary transactions in the convertible bond market is clearly sufficient to warrant careful research into the workings of the primary and secordary convertible markets, and into the nature of the issues traded in those markets.

\section{Arlene Hershman, "New Style in Convertibles," Dun's} Review, XCI (March, 1968), 43, 44. 
TABLE II

CONVERTIBLE BOND ISSUES OUTSTANDING

IN SELECTED YEARS, 1955-65*

(Excluding Small Issues Not Listed in Moody's Manuals)

\begin{tabular}{c|c|c}
\hline Year & $\begin{array}{c}\text { Estimated } \\
\text { Number of } \\
\text { Issues }\end{array}$ & $\begin{array}{c}\text { Estimated } \\
\text { Dollar Volume } \\
\text { (Billions) }\end{array}$ \\
\hline 1955 & 54 & $\$ 1.8$ \\
1957 & 110 & 1.8 \\
1959 & 182 & 2.6 \\
1961 & 220 & 2.5 \\
1963 & 223 & 1.8 \\
1965 & 222 & 3.4 \\
\hline
\end{tabular}

*Source: Robert R. McKenzie, "Convertible Debentures, 1956-65," The Quarterly Review of Economics and Business, VI (Winter, 1966), 42, 43; compiled from Moody's data.

\section{Characteristics of Convertibles and the Issuing Companies}

What sort of issues make up the convertible bond market, and what types of companies issue them? The answers can be found by examining such characteristics as average size of issue and issuing company, industry categories, risk of default, and the various debenture provisions.

Average Size of Issues and Companies

Drawing again upon $C$. James Pilcher's study, some idea of the average size of new convertible issues marketed in selected 
years between 1937 and 1952 can be gleaned from Table III; the table also provides average issue size on nonconvertible bonds. Private placements are excluded, as are small issues of $\$ 300,000$ or less. The percentages in the last column are particularly significant. Pilcher's interpretation (after examining other data as well) is that most convertibles are issued by either relatively small or relatively large companies (assuming a correlation between average issue size and average company size), with disproportionately few medium-sized companies involved. The smaller, weaker companies issue convertibles largely because they have little alternative. Larger companies, on the other hand, issue convertibles more sporidically--increasing their sales during times of popularity of convertibles, reducing their sales during times when stocks or straight debt instruments are more saleable. ${ }^{11}$ More will be said about this thesis later.

To the extent that the thesis is correct, it explains why the average issue size of convertibles, relative to all bonds, shrank in the 1941-43 period, then rose again later. Interest rates were pegged at a low level during the war, making straight bonds attractive as sources of new capital, and making the conversion feature a less attractive and less necessary device from the corporate viewpoint.

${ }^{11}$ Pilcher, Raising Capital With Convertible Securities, pp. 13, 14, 17, 18 . 
TABLE III

AVERAGE SIZE OF BONDS ISSUED IN SELECTED

TIME PERIODS, $1937-52$ **

Public Offerings in Excess of

$\$ 300,000$ Each

(Millions of Dollars)

\begin{tabular}{c|c|c|c}
\hline Year & $\begin{array}{c}\text { All Bonds } \\
(\mathrm{a})\end{array}$ & $\begin{array}{c}\text { Convertibles } \\
(\mathrm{b})\end{array}$ & $\begin{array}{c}\text { Ratio of } \\
(\mathrm{b}) \text { to }(\mathrm{a})\end{array}$ \\
\hline 1937 & $\$ 13.1$ & $\$ 13.5$ & $103 \%$ \\
$1941-43$ & 12.4 & 3.6 & 29 \\
1952 & 20.0 & 19.7 & 99 \\
\hline
\end{tabular}

*Source: C. James Pilcher, Raising Capital With Convertible Securities (Ann Arbor, 1955), p. 13 .

The main concern of this dissertation is with Iisted convertible issues. This narrows down almost exclusively to convertibles on the New York Stock Exchange, as explained in Chapter I. In a sample of twenty-nine convertible bonds listed on that exchange as of June 25, 1968, the mean average size of original issue was $\$ 42.4$ million. 12 In a larger sample, including some eighty issues with an earlier average issue date than the smaller sample, the mean average size was

12"New York Stock Exchange Bonds," The Wall Street Journal, XLI (June 25, 1968), 21. This sample was selected by picking every fifth convertible issue in the June 25, 1968, copy of the Wall Street Journal, for which data was available in the Moody's Manuals. The average year of issue in this sample was 1965 . A list of the issues appears in the appendix. 
\$31.1 milition. 13 These samples are not strictly comparable with Pilcher's because of changes in price level and because his sample includes both listed and unlisted issues. However, since Pilcher excluded small issues of $\$ 300,000$ or less, his sample should be compatible enough for a practical comparison after making an adjustment for price level changes. Table IV shows this comparison in terms of current prices.

\section{TABLE IV}

AVERAGE STZE OF CONVERTIBLES ISSUED IN SELECTED TIME PERIODS, 1937-68, IN CURRENT PRICES*

$$
\text { (Milizons of Dollars) }
$$

$$
\begin{aligned}
& \text { Period } \\
& \text { Average Size } \\
& \text { of Issue } \\
& 1937 \text {. . . . . . \$37.7 } \\
& \text { 1941-43......... } 8.3 \\
& 1952 \text {.......... } 27.7 \\
& \text { 1960**......... } 37.5 \\
& 1965 \text {. . . . . . . . } 45.7 \\
& \text { * Sources: Computed from data supplied } \\
& \text { by } C \text {. James Pilcher and by Moody's Nanuals. } \\
& \text { Implicit price deflator for GNP used to } \\
& \text { adjust prices. } \\
& \text { **Average age of } 80 \text {-issue sample. } \\
& \text { ***** Average age of 29-issue sample. }
\end{aligned}
$$

13 The Wall Street Journal, North Texas State University microfilm files. This sample of 80 issues was selected by picking every fifth convertible issue in the 1956, 1958, 1960, 1962, 1964, 1966, and 1968 Wall street Journals at mid-June, eliminating a few issues with unusual features (such as conversion features involving preferred stocks, or convertibles 
The increase in average issue size since 1952, while not dramatic, is nevertheless significant. It tends to substantiate and to build upon Pilcher's thesis. As interest rates have risen to punishing levels, larger companies have turned from straight debt issues to convertibles in an effort to keep coupon rates at a minimum. The twenty-nine-issue sample included such prestigious firms as Air Reduction, National Cash Register, Reynolds Metals, Trans-World Airlines, Lockheed Aircraft, Eastern Airlines, Burlington Industries, Commercial Solvents, and other corporations that certainly cannot be classified as small concerns. A study by the Wharton School of Finance and Commerce at the University of Pennsylvania disclosed that the average size of all corporate bonds issued in the first quarter of 1962 was $\$ 46.3$ million. 14 This confirms the belief that, relative to straight bonds, convertibles have not in recent years been issued by disproportionately small firms.

\section{Types of Industries}

There has been a trend toward greater diversity in the types of industries using convertible bonds as a source of new capital. Robert R. McKenzie states that over the 1955-65

involved in an exchange of securities in a merger). In computing average is sue size, an enormous $\$ 637$ milition issue marketed by American Telephone and Telegraph Co. was excluded. The average year of is sue in this sample was 1960. A complete list of the issues in this sample appears in the appendix.

14 Irwin Friend and others, Investment Banking and the New Issues Market (Cleveland, 1967), p. 325. 
period, the use of convertibles has "spread across industry categories."15 In terms of broad industrial classifications, Pilcher found that during the $1933-52$ period, 73.7 per cent of all convertibles he studied were issued by industrial. concerns, 22.0 per cent by utilities, 3.8 per cent by transportation companies, and 0.5 per cent by others (including financial institutions). 16 In the eighty-issue sample referred to earlier--covering convertibles issued during the 1952-68 period--84.9 per cent of the issues were in the industrial category, 5.0 per cent were utilities, 6.3 per cent transportation companies, and 3.8 per cent other.

Thus, the spreading use of convertibles has not been across major classification lines, but rather within the broad category of "industrial" companies. A wide array of specific industries was indeed evident in the "irdustrial" segment of the eighty-issue sample: chemicals, mail-order, steel, department and discount stores, distillers, machine tools, plastics, electronics, textiles, aircraft manufacturing, garment manufacturing, office equipment, foods, oil companies, paper companies, rubber, vending machine concerns, and conglomerates.

15Robert R. McKenzie, "Convertible Debentures, 1956-65," The Quarterly Review of Economics and Business, VI' (Winter, p. 19.

16pilcher, Raising Capital With Convertible Securities, 
Pilcher also found that industrial concerns made relatively greater use of convertibles-that is, relative to straight debt instruments--than did utilities, transportation companies, or others. Over the 1933-52 period, 17.4 per cent of the industrial issues were convertible, but only 4.0 per cent of the utility issues and 4.0 per cent of the transportation issues were convertible (the "other" percentage was distorted by the extremely small absolute number of issues involved and was not meaningful).17 Although no check was made on more recent issues, one must suspect that the same general ratios still hold. The reason is rooted in the financial policies and legal environment of utilities and railroad companies.

\section{Conversion Features}

There are several varieties of conversion features on convertible bonds. In the first place, while the great majority of such bonds are convertible into common stock, a few are, or have been in the past, convertible into preferred stock or a straight bond. The eighty-issue sample, described previously, including bonds issued from 1952 through early 1968, excluded two issues because they contained special conversion features. One was convertible into preferred stock, the other into a combination of common and preferred. Pilcher 
reports that such provisions were more common in the $1920^{\circ} \mathrm{s}$ but have been rare since then. 18

Another feature, one that has never been very popular, is the delayed conversion privilege--that is, a provision requiring the passage of a specified length of time before the holder can exercise the conversion privilege. In the eighty-issue sample, which picked up in terms of time where Pilcher's study stopped, only three bonds contained delayed conversion privileges--a mere 3.8 per cent. None were found in the somewhat "younger" twenty-nine-issue sample. From the corporation's viewpoint, there are arguments in favor of a delayed conversion feature. The strongest one, perhaps, is that delayed conversion gives the company time to invest the proceeds from sale of the convertible, and to begin generating earnings on the new funds before bondholders force a switch from lower-cost debt capital to higher-cost equity capital. It could be argued, on the other hand, that the period of greatest risk and uncertainty in a new investment venture is in its early stages, and that this is the, very time the company should avoid fixed interest charges and welcome the payout flexibility associated with equity canital. Whatever the pros and cons from the corporate viewpoint, the delayed conversion feature is rare in the marketplace because of its adverse effect on marketability, especially when a call feature is operative during the conversion delay period. 
Still another type of conversion feature, and one that has declined in prevalence, is the use of a conversion price that changes as a function of time or accumulated amount of previous conversions, or some combination of the two. Pilcher found that 64 per cent of the convertibles issued in the 1948-52 period had conversion prices that rose over the life of the issue 156 per cent at predetermined time intervals, 4 per cent based on accumulated conversions, and 4 per cent a combination of the two bases). ${ }^{19}$ Keith L. Broman, in a study of convertibles issued in the 1949-59 period, found that approximately 50 per cent of the issues had rising conversion prices. 20 . This represents a significant decline from Pilcher's earlier sample. In the twenty-nine-issue sample examined by this researcher--including bonds issued between 1955 and 1968--only two convertibles contained the rising conversion-price feature (less thar seven per cent). Since rising conversion price means a declining number of common shares received by the bondholder upon conversion, the apparent motive behind the use of such a feature is a desire on the part of the corporation to accelerate conversion. The feature obviously works to the detriment of the bondiolder who will, ceteris paribus, experience a loss in both conversion value and market price of the bond if he holds the bond through

\footnotetext{
19 Ibid., p. 30.

20 Keith L. Broman, "The Use of Convertible Subordinated Debentures by Industrial Firms 1949-59," The Querterly Review of Economics and Business, III (Spring, 1963 ), $\frac{\text { auet. }}{68}$
} 
an increase in conversion price. The feature calling for changes in conversion price at various levels of accumulated conversions is even more insidious, since it compels the bondholder to attempt to outguess the actions of fellow bondholders. The effect of the feature on marketability has probably accounted for the decline in the frequency of its use, particularly in this era of high interest rates, which have forced a large supply of new convertibles onto the market.

\section{The Call Provision and Duration of the Conversion Feature}

Another aspect of the conversion feature--one that can be most conveniently discussed along with the call feature--is the duration of the conversion privilege. This researcher's calculations based on data compiled by W. Braddock Hickman disclosed that, during the entire period from 1900 to $1943,62.5$ per cent of the dollar volume of new convertible issues in all industry categories contained conversion features that expired prior to the maturity date of the debt itself.21 (This does not, it should be noted, rule out changes in conversion price over the duration of the conversion privilege.) In Pilcher's sample during the 1948-52 period, only 20 per cent of the issues contained time

21W. Braddock Hickman, National Bureau of Economic Research, Statistical Measures of Corporate Bond Financing Since 1900 (Princeton, 1960), computed from data in Table 118, p. 211 . 
limitations on conversion.22 Arthur Dewing, in his 1953 text on corporate financial policy, called the limited conversion period an "exception." 23 None of the issues in the twenty-nineissue sample outstanding in 1968 had limitations on the duration of the conversion period. Thus, here is another variation of the conversion feature that has declined in use over the years; this one has, in fact, almost vanished entirely.

The original motive for placing a time limit on conversion was apparently to reduce, from the corporation's viewpoint, the period of uncertainty connected with the fact that conversion is at the bondholder's option. The limited conversion period forces, in most cases, a quicker transformation in the company's capital structure from debt to equity. If the company wants to speed up the switch from debt to equity-which many companies do--the limited conversion period is one way to force the speed-up. 24

The disappearance of the limited conversion period is explained largely by the increasing use of call provisions, which are now virtually universal in the case of convertibles. Normally, the bondholder is given a specified period of time, p. 48 .

22Pilcher, Raising Capital with Convertible Securities,

23Arthur Dewing, The Financial Policy of Corporations, 5 th ed. (New York, 1953), Vol. I, p. 264 .

24 This explanation conflicts with Pilcher's (pages 48-50 of Raising Capital With Convertible Securities); Pilcher's explanation seems illogical to this researcher. 
following the call notice, to convert the bond into stock. (In the twenty-nine-issue sample, all of the bonds were callable, one on twenty days' notice, the rest on thirty days' notice.) If the conversion value of the bond is above the call price at the time the bond is called, all rational investors will convert--or sell the bond for someone else to convert--in order to avoid losing the difference between the two amounts. The company can, in short, force conversion in such cases simply by calling the bond. Except for bonds with conversion values below call price, therefore, the call feature makes a limited conversion duration unnecessary. And when conversion value is depressed, conversion is not likely to take place in any case, making the limited conversion period meaningless.

An additional stimulus for doing away with the limited conversion feature is that, from the standpoint of marketability, investors are inclined to accept the call feature more readily than the limited conversion period. The limited conversion period can force the investor to either convert or to accept a straight debt instrument when neither alternative is desirable. A call provision on a convertible, on the other hand, is normaliy exercised only when the conversion value is above the call price; though an original buyer of the issue may be forced to convert before he wants to, he at least expects to turn a profit on the transaction. 
Anti-dilution Provisions

Virtually all convertibles, out of marketing necessity, contain clauses protecting the investor against dilution in conversion value arising from stock splits or stock dividends. The protection is provided very simply by adjusting the conversion price commensurate with the change in capitalization. For example, in a two-for-one split, the conversion price would be halved (or, to view it another way, the number of shares into which the bond could be converted would be doubled). Nany, but not all, convertibles also contain protection against dilution stemming from such things as sale of new common stock at less than the current market price, or the issuance of new convertibles with more favorable terms than the outstanding issue. Protection must also be provided against such acts as merger, consolidation, sale of assets, or dissolution of the company.

\section{Maturity}

A.high degree of uniformity exists among convertibles in respect to the original maturity period. Keith Broman found twenty to twenty-five years to be the typical maturity period.25 In the twenty-nine-issue sample, twenty-five of the bonds matured in either twenty or twenty-five years (the others were fifteen, eighteen, or twenty-one years). 


\section{Sinking Funds}

In a sample of convertibles issued in the $1948-52$ period, Pilcher found that about half of the issues contained sinking fund provisions; and he noted that sinking funds were less common for convertibles than for straight bonds (he estimated that seventy-six per cent of the straight secured bonds, and sixty per cent of the straight unsecured bonds, had sinking funds). 26 sinking funds represent a debatable financial arrangement on any bond, and in the case of convertibles they appear especially illogical in view of the common expectation that the corporation will never have to repay the principal because of conversion. One might, therefore, anticipate a decline over the years in the use of the sirking fund on convertibles. The trend, oddly enough, has been precisely the opposite. Broman, in his 1949-59 sample, found that a.lmost all of the issues had sinking funds of some kind. 27 In the more recent twenty-nine-issue sample, only two issues, or less than seven per cent, had no sinking fund provision.

Typically, however, the sinking fund payments are not only delayed several years from the issue date, but represent in total less than full face value of the debt. Broman found p. 54 .

26pilcher, Raising Capital With Convertible Securities,

27Broman, "The Use of Convertible Subordinated Debentures by Industrial Firms 1949-59," p. 68 . 
ten years a more or less normal delay. 28 In the twerty-nineissue sample, the period of delay ranged from four to fifteen years; eleven years was the most common. As for the portion of the debt covered by the sinking fund, there is great variety and ingenuity in the wording of this provision, with no phrasing that could really be regarded as typical. But just as an example, one of the twenty-nine issues included in the recent sample called for annual payments to start eleven years after the issue date, with annual payments that would, barring retirement of the issue by conversion or call, total approximately seventy-five per cent of the original principal amount; but the company could credit annual conversions against the required sinking fund payments and could, in addition, make extra voluntary payments if it desired.

The provision calling for total payments of less than the face value of the debt is entirely logical in the case of a convertible bond (unless, perhaps, the company also credits conversions against the required payments). But with a substantial time delay prior to the first annual payment, the sinking fund becomes largely farcial in terms of management's expectations at time of issuance, particularly since the call feature is usually expected to be available to force conversion. The sinking fund provisions appearing on most convertibles are, in short, little more than harmless "sweetners" 
added to the issues to make them more marketable. The limited degree of legitimacy they do possess lies outside of the realm, probably, of managerial expectations--namely, when the company falls upon hard times so that the bond remains unconverted and in danger of default. As will be observed in the following section, the increasing use of the sinking fund on convertibles cannot be attributed to rising default risk.

Risk of Default

The question of default risk is an important one in the case of convertibles; the common charge is that convertibles are typically issued by weak companies, are nearly always unsecured and subordinated, and have a poorer default record as a group than straight bonds. It is indisputably true that issuing convertibles without the security of a mortgage is a long-standing tradition. Thomas R. Atkinson ways, ".. For the first four decades of the century, never less than 70 per cent of the nonconvertible bond offerings were secured, whereas less than half and sometimes less than one-fourth. of the convertible issues were secured."29 In the recent twerty-nine-issue sample, all of the issues were unsecured and only one was not subordinated. The terms "convertible

29Thomas $R$. Atkinson, Trends in Corporate Bond Quality (New York, 1967), pp. 84, 86 .. For a $\frac{1}{\text { decade-by-decade record, }}$,
see p. 85. 
subordinates debenture" or just "convertible debenture" have become almost generic names for convertible bonds.

It is also true that convertibles are typically assigned less than top ratings by the rating agencies. Moody's ratings for the twenty-nine and eighty-issue samples are shown in Table V. 30

TABLE $V$

MOODY'S RATINGS OF THE CONVERTIBLES IN THE

TWENTY-NINE AND EIGHTY-ISSUE SAMPLES*

(Percentages of Totals)

\begin{tabular}{l|c|c}
\hline Rating & $\begin{array}{c}29-\text { Issue } \\
\text { Sample }\end{array}$ & $\begin{array}{c}\text { 8O-Issue } \\
\text { Sample }\end{array}$ \\
\hline A & $3.4 \%$ & $6.3 \%$ \\
Baa & 10.3 & 28.7 \\
Ba & 69.0 & 52.5 \\
Not rated & 13.9 & 8.8 \\
\hline Total & 3.4 & 3.7 \\
\hline
\end{tabular}

*Source: Moody's Manuals; ratings at time
of issuance.

The majority of the issues fall in the Baa or Ba categories, the fourth and fifth, respectively, down the list of Moody's symbols. Assigning quality ratings, however, is a tricky business. The rating agencies have been particularly bedeviled by convertibles in the past. In the prewar

30 The sequence of Moody's ratings, from highest to lowest, is: $\mathrm{Aaa}, \mathrm{Aa}, \mathrm{A}, \mathrm{Baa}, \mathrm{Ba}, \mathrm{B}, \mathrm{Caa}, \mathrm{Ca}, \mathrm{C}$. Some issues are not rated, and Moody's cautions against inferring any particular rating in such cases. 
period, Atkinson found a very poor correlation between agency ratings on convertibles and subsequent default rates, stating, "The rating agencies have apparently had as much difficulty with convertibles as investors have had."31 Atkinson does not, unfortunately, provide evidence on the predictive accuracy of ratings in the postwar period. Unquestionably, however, convertibles as a group have been rated lower than nonconvertibles in the postwar period, as indicated by Atkinson's data in Table. VI.

\section{TABLE VI}

PERCENTAGE OF NEW BOND ISSUES WITH MOODY'S RATINGS BELOW Baa, 1944-65\%

(Public Offerings Only)

\begin{tabular}{c|c|c}
\hline Period & Convertibles & $\begin{array}{c}\text { Non- } \\
\text { Convertibles }\end{array}$ \\
\hline $1944-47$ & $2.1 \%$ & $3.3 \%$ \\
$1948-51$ & 6.9 & 1.3 \\
$1952-55$ & 9.5 & 1.4 \\
$1956-59$ & 36.7 & 1.5 \\
$1960-63$ & 62.2 & 1.7 \\
$1964-65$ & 87.2 & 5.8 \\
\hline
\end{tabular}

* Source: Thomas R. Atkinson, Trends in Corporate Bond Quality (New York, 1967), p. 88; computed from data in Moody's Bond Survey.

One of the difficult questions in assigning ratings is the amount of weight to give to the fact that a bond is unsecured, or subordinated, or both. These features 
automatically preclude assignment of top ratings by the rating agencies. But, as Graham, Dodd, and Cottle point out, "The debenture (i. e., unsecured) obligations of a strong corporation, amply capable of meeting its interest charges, may qualify for acceptance almost as readily as its bonds secured by mortgage. Furthermore, the debentures of a strong enterprise are undoubtedly sounder investments than the mortgage issues of a weak company." 32 Assigning a low rating because a company has a questionable level of credit-worthiness is one matter; automatically assigning a low rating because a bond is not secured and/or is subordinated is another matter. Such a practice can be called into question. What about the actual default record of convertibles compared with straight bonds? The fact is, the default reputation picked up by convertibles was acquired in one decade, the $1920^{\prime} \mathrm{s}$. Provided the default rate is computed properly, convertibles as a class have experienced a lower default rate for all other decades in the prewar period, as shown in Table VII. (Unfortunately, comparable data for the postwar period are not available; this will be discussed below).

The manner in which the default percentages are computed is crucial. If the rates are computed by dividing Security Analysis, Principles and Technique, 4th ed. (New York, 1962), p. 313 . 
current dollar default volume for a given time period by the total dollar volume of bonds outstanding at the beginning of that time period, distortions can be caused by a rising or declining issue volume bearing no direct relationship to the default volume itself. Furthermore, additional distortion occurs in the case of convertibles because of the tendency for "default-proof" convertibles--those associated with rising per-share stock prices and profitable conversion values--to be converted and thus removed from the figure on outstanding dollar volume; while the "default-prone" issues remain unconverted and thus weigh disproportionately in the aggregate volume of outstanding issues.

\section{TABLE VII}

DEFAULT RATES ON CONVERTIBLE AND NONCONVERTIBLE BONDS, 1900-43*

(Dollar Figures in Millions)

\begin{tabular}{|c|c|c|c|c|c|c|}
\hline \multirow[b]{2}{*}{$\begin{array}{l}\text { Period } \\
\text { of } \\
\text { Issue }\end{array}$} & \multicolumn{3}{|c|}{ Convertibles } & \multicolumn{3}{|c|}{ Nonconvertibles } \\
\hline & $\begin{array}{l}\text { Dollar } \\
\text { Volume } \\
\text { Issued }\end{array}$ & $\begin{array}{l}\text { Doliar } \\
\text { Volume in } \\
\text { Default }\end{array}$ & $\begin{array}{l}\text { Default } \\
\text { Rate }\end{array}$ & $\begin{array}{l}\text { Dollar } \\
\text { Volume } \\
\text { Issued }\end{array}$ & $\begin{array}{l}\text { Dollar } \\
\text { Volume in } \\
\text { Default }\end{array}$ & $\begin{array}{c}\text { Default } \\
\text { Rate }\end{array}$ \\
\hline $1900-10$ & $\$ 1211.3$ & $\$ 235.6$ & $19.5 \%$ & $\$ 10909.1$ & $\$ 3962.1$ & $36.3 \%$ \\
\hline $1911-20$ & 1386.3 & 315.6 & 22.8 & 10856.6 & 2983.4 & 27.5 \\
\hline $1921-30$ & 2620.3 & 925.9 & 35.3 & 22786.7 & 5167.7 & 22.7 \\
\hline $1931-40$ & 1264.8 & 36.5 & 2.9 & 16796.8 & 950.4 & 5.7 \\
\hline $1941-43$ & 302.4 & 0.0 & 0.0 & 3410.0 & 32.2 & 0.9 \\
\hline $1900-43$ & 6785.1 & 1513.6 & 22.3 & 64759.2 & 13095.8 & 20.2 \\
\hline
\end{tabular}
*Source: Issue volume computed from Table I. Default data compiled by Thomas R. Atkinson, Trends in Corporate Bond Quality, p. 80, from information on file at the National Bureau of Economic Research. 
The proper computation is to group the default volume by year of issue and to divide the total annual default volume by the issue volume to which it corresponds. This is the basis on which Table VII was constructed. 33

Immediately apparent from the table is the fact that the default record on both types of bonds was poor for bonds issued through the $1930^{\prime} \mathrm{s}$. The debacle of the 1920's is, of course, the main culprit. (It should be noted, as just explained, that bonds shown in Table VII in the 1900-10 or 1911-20 rows did not necessarily go into default in those years; the depression era undoubtedly took its toll of older as well as recently-issued bonds.) It is also apparent that an inordinately large volume of defaul-prone convertibles was issued in the 1920's. Many companies, sady lacking in credit-worthiness by today's standards, added the conversion "sweetener" to debt issues and sold large volumes of debt securities to enthusiastic investors whose insensitivity to the impending crisis is an oft-told tale. Nany sounder convertibles, like their nonconvertible cousins issued throughout the early twentieth century, also went into default. Combined, this meant an absolute volume of defaults on convertibles that established their reputation as a weak, default-prone type of security to which the issuer had to

33 Atkinson is aware of the difference between the two approaches (Trends in Corporate Bond Quality, p. 93) but for some inexplicable reason chose to base his main conclusions regarding default on the distorted percentages. 
add the conversion feature to market the security at all, or at least at a reasonable price. Like other reputations earned in moments of crisis, this one has stubbornly persisted.

The overall default rate on convertibles for the 1900-43 period was 22.3 per cent, only slightly higher than the 20.2 per cent rate for nonconvertibles. The decade-by-decade record shown in Table VII speaks for itself.

No comparable default data on the postwar period could be found, but other types of information provide some clues on the postwar performance of convertibles. It is important, in interpreting the comments of various researchers, to understand a characteristic more or less peculiar to the convertible bond market. It will be recalled from the discussion on pages 26-30 of this chapter, and from the analysis immediately above, that companies issuing convertibles tend to fall into two conflicting groups: small, weak concerns that sell convertibles because they are unable to market other debt or equity instruments; and larger, stronger companies that invade the convertible market sporadically, when marketing conditions appear more favorable than in other markets. There is, in other words, a base of small companies whose issue volume is relatively stable through time, and layered onto this base is a group of companies whose issue volume vacillates through time. This accounts in large measure for the observed peaks and valleys in aggregate issue volume, in the ratio of new convertible issue volume to nonconvertible volume, in 
average size of new issues, and in average credit-worthiness of the issues. 34 Thus, one might make some intelligent guesses about the general quality of convertibles in the postwar period by studying the data in Table I on page 24 . In regard to the ratio of the dollar volume of new convertible issues to the volume of all bonds, the percentages by decade since 1930 are $1930^{\prime} \mathrm{s}, 6.7$ per cent; $1940^{\circ} \mathrm{s}, 6.6$ per cent; $1950^{\prime} \mathrm{s}, 13.1$ per cent; and 1960 through 1967, 11.6 per cent. Overall, this ratio has clearly not declined in the postwar period. As for absolute volume, the dollar volume of new convertible issues, in terms of averages for successive decades in constant dollars, has risen each decade since the 1930's. The average for the 1960's (through 1967) shows an increase of 195 per cent over the average of the 1930 's, 192 per cent over the average of the 1940's, and 4 per cent over the average of the 1950's. This compares

34 In addition to Pilcher's observations referred to on pages 26-30 of this chapter, also see McKenzie, "Convertible Debentures, 1956-65," p. 51. Atkinson's data also substantiates this thesis, although Atkinson himself did not seem to fully appreciate the nature of his findings. He says, on page 79 of Trends in Corporate Bond Quality, that there is". . . a tendency for the years that produced high-grade convertible bonds to produce low-grade nonconvertibles and vice versa [reflecting a switch by the larger companies from one market to the other]. . . In general, years that produced a high proportion of convertibies ultimately going to default were those years. when convertibles were relatively scarce [again, reflecting the fact that the larger companies had temporarily vacated the convertible market]. This suggests that the high volume of convertibles issued in the postwar period does not in itself mean an increased incidence of convertible bond defaults." (Notations in brackets added). 
with 71 per cent, 65 per cent, and 17 per cent, respectively, for nonconvertible bonds. And Table IV (page 29) shows that the average size of new convertible issues in constant dollars has risen in the postwar era. Although such indirect data cannot provide conclusive proof regarding the quality of convertibles in the postwar era, they at least cast suspicion on any charge that average quality of convertibles has declined.

This is precisely the charge made by Atkinson, who claims that the quality of convertibles has deteriorated in the postwar period.35 There are, however, some serious defects in Atkinson's analysis. His analysis is based largely on earnings-coverage figures and on agency ratings in the postwar period. The agency ratings on convertibles may well have declined relative to the prewar period; but after Atkinson's own observation of the low correlation between agency ratings and subsequent defaults in the prewar period, and without supplying any evidence of improvement in the postwar accuracy of the agency ratings, use of the agency. ratings to measure quality in the postwar period seems a rather astonishing violation of sound methodology.

As for the earnings-coverage figures, Atkinson provides clear evidence of a downtrend in the postwar figures, as shown in Table VIII on the following page. 
TABLE VIII

EARNINGS-COVERAGES ON CONVERTIBLES AND

NONCONVERTIBLE BONDS IN SELECTED

PERIODS, $1945-65 *$

\begin{tabular}{c|c|c}
\hline Period & Convertibles & Nonconvertibles \\
\hline $1945-51$ & $13.7 \mathrm{X}$ & $17.8 \mathrm{X}$ \\
$1952-58$ & $9.5 \mathrm{X}$ & $13.6 \mathrm{X}$ \\
$1959-65$ & $4.0 \mathrm{X}$ & $10.9 \mathrm{X}$ \\
\hline
\end{tabular}

*Source: Thomas R. Atkinson, Trends in Cornorate Bond Quality (New York, 1967), p. 88.

The question is, how meaningful are traditionally computed earnings-coverage figures in measuring the quality of convertibles? First, it should be noted that the earningscoverage on nonconvertibles has declined also, reflecting, perhaps, a modern trend toward greater use of financial leverage. Secondly, since nearly all convertibles are subordinate to other debt, use of the "cumulative-deductions" method of computing earnings-coverages, as was done in Table VIII, means an inevitably lower figure on convertibles than on other debt, to the extent that each company involved in the study had both convertibles and nonconvertibles outstanding. The "overall" or "total-deductions" method advocated by Graham, Dodd, and Cottle woula produce more nearly equal coverage figures for the two categories of bonds.36 Thirdly, despite the usual

36 Graham, Dodd, and Cottle, Security Analysis, 4 th ed., pp: 346,47 . An additional variable deserving of some consideration, however, is the possible presence of bank debt which, 
twenty to twenty-five year maturity period of convertible bonds, most issues experience heavy conversion rates within a few years after issuance; the twenty-nine-issue sample described previously contained bonds with an average age of only about three years, for example. Broman's study of convertibles in the $1949-59$ period indicated much the same tendency toward rapid conversion. He states, "Of the 28 issues outstanding in an amount greater than 95 per cent of face value, 11 were issued in the last two years of the study."37 Many convertibles are sold as a means of selling common stock indirectly; rapid conversion is planned by management and will be forced, if necessary, by exercise of the call feature. In such cases, inclusion of convertible bond interest in total fixed charges can distort earningscoverage computations. Another manifestation of this distortion is the tendency for the debt/equity ratios of companies marketing a convertible issue as an indirect means of selling stock to be temporarily higher than industry averages until conversion is effected. 38 Prior to such conversion, the excess debt adversely influences earningscoverages of convertible-issuing companies as a group relative to companies with no convertibles outstanding; after conversion, a convertible-issuing company simply switches to the

37 Broman, "The Use of Convertible Subordinated Debentures by Industrial Firms, 1949-59," p. 73 .

${ }^{38}$ Ibid., pp. 73, 74 . 
nonconvertible-issuing category and no improvement occurs in the average earnings-coverage of the convertibleissuing group. This collection of statistical and other influences can lead to spurious interpretations of traditional eamings-coverage figures.

Traditional measures of "quality" may not, in short, be appropriate in the case of convertibles. And when such measures are combined with agency ratings which are also based on traditional measures, the results may be highly questionable. Some new research is needed on measuring devices before applying them to actual quality measurements of convertibles. This was the step omitted by Atkirson. Unfortunately, it is also beyond the scope of this study. Also missing are default data for the postwar period comparable to the National Bureau of Economic Research data used to construct Table VII. The postwar default risk of convertibles as a group must consequently be regarded as an open question, until both better measurement theories and better measurement data are developed.

There is little doubt that the larger, more credit-worthy companies are largely responsible for the huge upsurge in volume of convertible issues since 1965. Sidney Fried of R. H. M. Associates (an advisory service specializing in convertibles) was quoted as saying, "There is no question that converts have penetrated further and further into the blue chips. Maybe U. S. Steel and General Motors have not tried 
them yet, but practically everybody else has."39 How long this current phase of invasion into the convertible market by the big companies will continue is, of course, a matter of conjecture.

Risk of default is only one of the risks faced by convertible bond investors, and, in the case of listed convertibles at least, a less important risk than the others. As an offset to additional risk, convertibles are potentially more profitable than straight bonds. Whether the realized rate of return on listed convertibles--the actual net return after any losses associated with the various risk elements --is greater on convertibles than on straight debt issues, is a question investigated in the next chapter.

\section{Motives Underlying Issuance of Convertibles}

The nature of the convertible bond market cannot be thoroughly understood without examining in more detail the motives underlying the issuance of convertibles by corporations. There are three major motives and several supplementary ones.

Major Motives

The major motives are (1) to "sweeten" debt issues to make them marketable, (2) to effect an indirect and delayed sale of common stock, and (3) to reduce coupon rates in 
periods of generally high interest rates. These three motives are all quite distinct.

The "sweetener" motive is associated with less creditworthy companies that must add an additional seling feature to market any kind of capital instrument to the investing public, or perhaps with companies that could sell a stock issue but could not sell a debt issue without the "sweetener." The "sweetener" motive comes particularly to mind in connection with the flood of default-prone issues in the late $1920^{\prime} \mathrm{s}$. As several researchers have emphasized, however, the "sweetener" motive has been overstressed. Pilcher, for example, says, "The implication that the vast majority of convertibles are low quality securities seems unfounded at least with respect to corporate financing in recent years. 140 Less than twenty per cent of 100 managements surveyed by Pilcher claimed the "sweetener" motive as their reason for issuing convertible securities. 41 Broman says," . The historic use of the conversion clause, to 'sweeten' an issue, is no longer of singular importance."42 The defaut data analyzed on previous pages help substantiate such comments. p. 59 .

40Pilcher, Raising Canital With Convertible Securities,

$4^{1}$ Ibjd., pp. 59-62.

42 Broman, "The Use of Convertible Subordinated Debentures by Industrial Firms 1949-59," pp. 74, 75. 
A milder version of the "sweetener" motive occurs in the case of companies that could sell a stock issue but prefer the advantages of debt capital and must use the "sweetener". to sell bond issues. Convertible debt, like any debt, carries the advantages of financial leverage, tax deductibility, and lower flotation cost (flotation cost is discussed below). Still a more positive motive for issuance of convertibles is the minimization of cost of capital relative to straight debt. Charles Clayton Brown, in dissertation research at the University of Washington, hypothesized that

Moderate use of convertible bond financing in lieu of straight debt was predicted to result in a lower overall cost of capital because of the decreased financial risk stemming from lower fixed charges for convertible bonds. Eventually, however, potential dilution of common share earnings from possible conversion would cause the capitalization rate for equity to rise, thereby causing the overall cost of capital to increase. 43

Although Brown was unable to completely verify the hypothesis, the concept is both interesting and meaningful.

The second major motive for issuing convertibles is as a means of marketing common stock indirectly and with a time delay. Pilcher's survey of 100 companies found this to be the main motive in over eighty per cent of the cases. 44

43 Charles Cleyton Brown, "Convertible Bonds and the Cost of Capital: Some Theoretical Considerations and Empirical Findings," abstract of doctoral dissertation, University of Washington, 1966. pp. 59-62.

44Pilcher, Raising Capital With Convertible Securities, 
Broman says, ". . It appears likely that the convertible subordinated debenture has been used as a bridge toward equity ownershio rather than as a long-term debt issue with added sale inducements."45 A company marketing convertibles under this motive would desire relatively rapid conversion of the bonds into stock, whereas a company selling convertibles under the "sweetener" motive would often prefer slow conversion or no conversion at all.

The logic behind an indirect and delayed sale of stock, via sale and subsequent conversion of a convertible bond issue, is the expectation of higher proceeds than would be realized from a direct sale of common stock. Convertibles are normally sold with a conversion value somewhat below, the original selling price of the bond. Broman found discounts of from six to fifteen per cent on most issues. 46 This means that, with a given desired level of proceeds, the bond will, after conversion, result in issuance of a smaller number of shares than will a direct sale of common shares. Or, alternately stated, with a given number of common shares, the convertibles will bring in greater aggregate proceeds than a direct sale of common stock. For example, if common stock could be sold for $\$ 90$ a share, the conversion price of a convertible bond could perhaps be set at $\$ 100$, meaning that

45 Broman, "The Use of Convertible Subordinated Debentures by Industrial Firms 1949-59," p. 73 .

46 Ibid., p. 72 . 
the bond would be convertible into ten shares of stock. This is tantamount, after conversion, to having sold the stock for $\$ 100$ a share rather than $\$ 90$.

The marketability of convertibles under such advantageous circumstances hinges importantly upon investor expectations as to future upward movements in the secondary market price of the stock; without such an expectation, investors will be unwiling to pay a premium over the current conversion value of the bond or to accept a coupon rate which is lower than that on a competitive straight debt instrument. It is for precisely this reason that convertibles tend to be more popular in periods of rising stock prices. As J.M. Keynes explained:

It would be foolish, in forming our expectations, to attach great weight to matters which are very uncertain. It is reasonable, therefore, to be guided to a considerable degree by the facts about which we feel somewhat confident, even though they may be less decisively relevant to the issue than other facts about which our knowledge is vague and scanty. For this reason the facts of the existing situation enter, in a sense disproportionately, into the formation of our long-term expectations; our usual practice being to take the existing situation and to project it into the future, modified only to the extent that we have more or less definite reasons for expecting a change. 47

The positive correlation between new-issue volume of convertibles and buliish stock market movements--although far from perfect as will be seen below--has been observed by numerous

47 John Maynard Keynes, The General Theory of Employment,

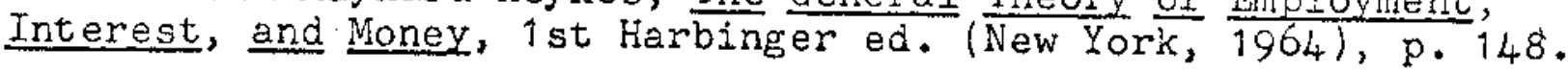


other researchers. Atkinson, for example, says, "Rises in the volume of convertible bond offerings tend to coincide with increases in stock prices and fall of $f$ at or after declines in the stock market." 48 Atkinson also comments, "The rising stock market throughout most of the postwar period made convertibles the cheapest method of external. financing for many corporations." 49

So-called growth companies, as one might expect, particularly lend themselves to sale of convertibles at premium prices in bull markets when investors are optimistic. The smaller, less promising concerns tend, in general, to sell stock directly, or to issue convertibles under the "sweetener" motive.

The third major motive underlying the issuance of convertibles--to reduce coupon rates in periods of generally high interest rates in the straight debt market--is a relatively new one, at least for this generation of researchers. It is distinguished from the "sweetener" motive by the fact that the coupon rates on straight debt are high not because of credit weakness on the part of the individual company, but because of generally high interest rates. Pilcher makes no clear mention of this motive, probably because his research came prior to the sustained $r i s e$ in interest rates beginning in the mid-1950's. Nor does Broman mention it. Recent

48 Atkinson, Trends in Corporate Bond Quality, p. 86. 49 Ibid., p. 76. 
observers, however, are acutely aware of this motive for sale of convertibles; it is believed to be one of the prime forces behind the onslaught of large companies into the convertible market since 1965.50

At least two of the major motives, if not all three, have influenced the volume of convertible offerings over the years. Any attempt to condense the motives down to one or two, or to oversimplify any one of them, leads to unsatisfactory explanations of variations in issue volume, except perhaps for specific time segments within the long span. For example, while it is true that the volume of convertible offerings if positively correlated with bullish stock price movements, the correlation is not high. Based on annual. new-issue volume since 1900 and movements in the Dow-Jones Industrial Average, the coefficient of correlation is 70.3 -certainly a significant level, but indicating that only about half of the year-to-year variation in new-issue volume is explained by variations in the Dow-Jones average. With a six-month lead in the Dow-Jones Industrial Average, the coefficient of correlation is 67.5. Part of the unexplained variation in issue volume is almost certainly attributable to the existence of "sweetener firms" whose aggregate issue volume through time is not highly sensitive to movements in the

50For example, see Ashby Bladen, "Convertible Debentures: An Analyst Finds Many of Them on the Bargain Counter," Barron's, XIVIII (Jan. 8, 1968), p. 5ff.; or Hershman, "New 
stock market. And part of it is probably explainable in terms of changes in interest rates that are not, in simple or reliable fashion at least, related, to changes in stock prices.

A recent article by Robert $R$. McKenzie represents another type of oversimplification in the explanation of new-issue volume. McKenzie implicitly denies the validity of the "indirect sale of stock" motive, stating that, "Evidence indicates that convertibles are [for larger companies] a substitute for straight debt and that convertibles provide an auxiliary source of funds when capital investment is heavy and places a strain on more conventional sources of [debt] funds." 51 McKenzie measures this "strain" by tracking the magnitude, through time, of the prevailing spread between the average yield on convertibles and the yield on nonconvertibles, along with the volume of plant and equipment expenditures'. He expresses the yield spread as an index, a ratio of the yield on straight debt to the yield on convertible debt. When the ratio rises, and when piant and equipment expenditures are heavy, he hypothesizes, the expanding firms will move into the convertible bond market and out of the straight debt market. Of the two independent variables used in his multiple

${ }^{51}$ Mickenzie, "Convertible Debentures, 1956-65," p. 51. Brackets added. McKenzie grants--in fact, stresses--the existence of the "sweetener" motive and is a major advocate of the thesis that there is a base of smali companies on to which are layered larger companies that alternate from one type of security to another. (See his pp. 45, 51.) 
regression analysis, the yield spread is the main concern here; regarding it, McKenzie says, "We have argued here that new issues of convertibles are induced by shifts in the yield index: the ratio of interest rates on straight debt and convertibles. A low ratio reduces new issues and a high ratio acts as an incentive to issue convertibles in lieu of straight debt." 52

In terms of mechanics, McKenzie substantiates his hypothesis. His error, however, lies in a narrow interpretation of what the yield index represents. The yield index is not a measure only of management's interest in alternative types of debt issues. It is also a measure, to some undeterminable extent, of management's interest in the indirect sale of stock as an alternative to the sale of straight debt. This is true because the yield index is partly a function of the speculative premium on outstanding convertibles and the strength of the stock market. When investors and speculators bid convertibles up to premium prices (over conversion or intrinsic value) and when stock prices are rising, the yield on convertibles is low. But this is precisely the condition under which an indirect sale of stock, via sale of a convertible issue, is most opportune. McKenzie has thus incorrectly glossed over the "indirect sale of stock" motive.

Although he has oversimplified the motives for issuing convertibles, one offshoot of McKenzie's study is of 
considerable significance--namely, the observation that it is not the absolute level of interest rates that governs management's movements from the debt market to the equity market (either via convertibles or directiy) or vice-versa. It is the difference in yield or cost of capital between the markets. If total supply of capital is assumed to be fixed, or at least not rising, high interest rates on straight debt are a conseguence of heavy demand for straight debt. Hence, it is self-contradicting to state that high rates deter the use of straight debt. Thus, it is not technically correct to imply, as was done in describing the third major motive for issuing convertibles, that the volume of convertible issues rises in response to rising absolute rates in the straight debt market. Such a statement is satisfactory as a sort of shorthand notation. But, to be accurate, one should interpret the statement to mean that total demand in all capital markets is high relative to supply, and that, if the markets are working perfectly, just enough of the incremental demand will be directed toward the convertible bond market to eradicate any cost-of-capital advantage that market possesses.

\section{Supplementary Motives}

There are several supplementary motives for issuing convertible bonds as an alternative to other types of securities. The convertible is one way to bridge the gap between recejpt of new capital by a corporation and generation of earnings sufficient to meet the higher cost of equity 
capital and to avoid immediate dilution of stockholders ${ }^{\prime}$ equity. The convertible bond would be more useful in this respect to, say, a steel company building a new mill than to a company, such as a bank, that can put new funds to work rapidly.53 on the other hand, as was suggested earlier, the use of debt capital during the early phases of a new investment project could have adverse rather than beneficial effects; if the fixed charges cannot be comfortably met, the payout flexibility associated with a direct stock sale might be preferable to the payout requirements of a convertible. Another advantage of the convertible is that it may tap a segment of the capital market that could not be reached with either a straight bond or a straight stock issue. The division of investors into risk-seeking and risk-averting categories may produce a gap or segmentation in the capital markets. If the yields on stock rise because of heavy demand by corporations for venture capital relative to the supply of such capital, risk-averting investors will not necessarily move in to fill the void. Market segmentation prevents a. flow of funds out of straight bonds or other conservative investments and into stocks. Convertibles may succeed in luring risk-averting investors into the capital market, because of the dual role of a convertible as a debt and equity

53George J. Leness, Gillette K. Martin, and Roger $T$. Gilmartin, New Money for Business, Technigues of Long-term Corporate Einancing (New York, 1956), pp. 39, 40. 
instrument. 54 This advantage of convertibles is conceptually related to the "indirect sale of stock" motive discussed previously, and represents another reason why that motive should be described separately and not blended in with either of the other two major motives.

Still another advantage of convertibles, relative to stock issues at least, is a generally lower flotation cost. Computation of flotation costs is a deceptively complicated affair and the subject will not be pursued in any depth here. Flotation cost is affected by many things in addition to the type of security, including the size of the issue, strength or reputation of the issuing corporation, whether an investment banker is involved and, if so, the length and nature of the underwriting commitment, market conditions, whether the offering price is realistic, and whether public or private placement is used. It is difficult to make a direct comparison of flotation costs between stocks and convertible bonds because of the numerous other variables impinging on the situation. Generally speaking, however, the flotation cost of convertibles --in terms of the sum of investment bankers' commissions and the out-of-pocket expenses--lies somewhere between the cost of straight bonds and the cost of preferred stock. Arraying all four major types of securities, the sequence from lowest

54 If this thesis is valid, yields on convertibles would logically fall somewhere between yields on stocks and on straight debt. Empirical evidence of this relationship is presented in Chapter III. 
to highest flotation cost would be: Straight bonds, convertible bonds, preferred stock, common stock.55

A final reason for marketing convertibles rather than other types of securities has to do with the emergence of institutional investors as a powerful force in the capital markets. The following special section is devoted to this subject.

\section{Institutional. Investors}

In the security markets in general, the influence of institutional investors has grown to enormous proportions. Individual investors have, correspondingly, declined in relative importance--and, in the case of stocks, in absolute importance--as shown in Table IX. This table indicates, very simply, that institutions have been net buyers of corporate securities, while individuals have been net sellers since 1958. This trend started, as a matter of fact, in the late $1940 \mathrm{~s} .56$ (Table IX excludes bank trust

55 For those who wish to pursue the question of flotation costs, the following references are useful: Securities and Exchange Commission, Cost of Flotation, 1945-1949 (Washington, 1954); Securities and Exchange Commission, Cost of Flotation of Corporate Securities, 1951-1955 (Washington, 1957); Securities and Exchange Commission, Privately-Flaced Securities - Cost of Flotation (Washington, 1952); Leness, Martin, and Gilmartin, New Money for Business, Techniques of Lone-term Corporate Financing, $\mathrm{p}, 116$; and Pilcher, Raising Capital With Convertible Securities, p. $8 \%$.

56Friend and others, Investment Banking and the New Issues Market, pp. 70, 71 . 
account investments; as will be discussed below, the asset holdings in these accounts are of staggering proportions,)

\section{TABLE IX}

ANNUAL NET PURCHASES OF CORPORATE STOCKS AND BONDS BY INDIVIDUALS AND FINANCIAL INSTITUTIONS, $1957-66 *$

(Billions of Dollars)

\begin{tabular}{|c|c|c|c|c|c|}
\hline & 1957 & 1958 & 1959 & 1960 & 1961 \\
\hline $\begin{array}{c}\text { Institutions } \\
\text { Bonds } \\
\text { Stocks }\end{array}$ & 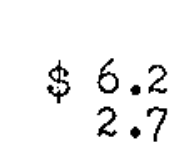 & $\begin{array}{r}\$ 5.2 \\
3.2\end{array}$ & $\begin{array}{r}\$ 4.0 \\
3.5\end{array}$ & $\begin{array}{r}\$ 4.5 \\
3.7\end{array}$ & $\$ \begin{array}{l}5.0 \\
4.8\end{array}$ \\
\hline Total & $\$ 8.9$ & $\$ 8.4$ & $\$ 7.5$ & $\$ 8.2$ & $\$ 9.8$ \\
\hline $\begin{array}{c}\text { Individuals } \\
\text { Bonds } \\
\text { Stocks }\end{array}$ & $\begin{array}{r}\$ 0.8 \\
-\quad 0.1 \\
\end{array}$ & $\begin{array}{r}\$ 0.7 \\
-\quad 1.0\end{array}$ & $\begin{array}{r}\$ 0.1 \\
-\quad 1.5\end{array}$ & $\begin{array}{r}\$ 0.5 \\
-\quad 2.2 \\
\end{array}$ & $\begin{array}{r}\$ 0.3 \\
-\quad 2.4 \\
\end{array}$ \\
\hline Total & $\$ 0.7$ & $-\$ 0.3$ & $-\$ 1.4$ & $-\$ 1.7$ & $-\$ 2.1$ \\
\hline & 1962 & 1963 & 1964 & 1965 & 1966 \\
\hline $\begin{array}{c}\text { Institutions } \\
\text { Bonds } \\
\text { Stocks }\end{array}$ & $\begin{array}{l}5.8 \\
4.3\end{array}$ & $\begin{array}{r}\$ 5.3 \\
4.5\end{array}$ & $\$ \begin{array}{l}6.2 \\
4.7\end{array}$ & $\begin{array}{l}\$ 7.1 \\
6.7\end{array}$ & $\begin{array}{l}\$ 8.5 \\
5.6\end{array}$ \\
\hline Total & $\$ 10.1$ & $\$ 9.8$ & $\$ 10.9$ & $\$ 13.8$ & $\$ 14.1$ \\
\hline $\begin{array}{c}\text { Individuals } \\
\text { Bonds } \\
\text { Stocks }\end{array}$ & $\begin{array}{l}-\$ 0.8 \\
-\quad 3.7 \\
\end{array}$ & $\begin{array}{r}\$ 0.3 \\
-\quad 4.9 \\
\end{array}$ & $\begin{array}{r}\$ 0.4 \\
-\quad 3.0\end{array}$ & $\begin{array}{r}\$ 1.0 \\
-\quad 6.2\end{array}$ & $\begin{array}{r}\$ 2.5 \\
-\quad 4.7\end{array}$ \\
\hline Total & $-\$ 4.5$ & $-\$ 4.6$ & $-\$ 2.6$ & $-\$ 5.2$ & $-\$ 2.2$ \\
\hline
\end{tabular}

* Source: Adapted from data compiled by Sidney Homer of Salomon Brothers and Hutzler. Includes mutual savings banks, life insurance companies, fire and casualty companies, private noninsured pension funds, state and local retirement funds, mutual funds, and commercial bank investments excluding trust accounts. 


\section{The Various Institutions}

The institutions most importantly involved in the purchase of corporate securities include life insurance companies, fire and casualty companies, private noninsured pension funds, state and local retirement funds, commercial or savings banks (including trust accounts), mutual funds or closed-end investment companies, and educational, religious, or charitable organizations.

Total assets of life insurance companies were estimated to be $\$ 167$ billion in $1966.5 \%$ The life insurance industry, of all the institutions, has traditionally been the largest net purchaser of corporate securities, mainly bonds and preferred stocks. Private noninsured pension funds have; however, overtaken life insurance companies in the volume of corporate security purchases. T'otal purchases of corporate stocks and bonds in the 1957-66 period was $\$ 24.1$ billion for life insurance companies and $\$ 39.4$ billion for the private noninsured pension funds. 58 The pension funds have stressed equity purchases 162.2 per cent of total dollar cost of 1957-66 acquisitions) whereas life insurance companies have continued, though somewhat less emphatically than in the

57 Institute of Life Insurance, 1967 Iife Insurance Fact
p. 61. Book, p. 61 .

58 Sidney Homer, "The Impact of Corporate Pension Funds on Equity and Bond Markets," The Commercial and Financial Chronicle, $\operatorname{CCV}(\mathrm{Feb} .23,1967), 806$. 
past, to favor debt instruments $(86.3$ per cent of total dollar cost of 1957-66 acquisitions).

There are now an estimated 50,000 private pension funds with total assets in excess of $\$ 90$ billion. 59 This is still less than aggregate life insurance company assets, but if the present growth rates continue, the positions will reverse in the near future. One researcher predicts that private pension fund assets will total $\$ 222$ billion by 1980,60

There are, of course, pension funds other than the private noninsured funds. At the end of 1960, there were an estimated 120,500 pension plans of all types. 61 This figure presumably includes not only the insured funds but the state and municipal pension funds, privately managed corporate plans, privately managed labor union funds, and pension funds managed by bank or other trustees. The union pension funds, for example, now hold an estimated $\$ 4$ billion in assets and are one of the fastest growing types of pension funds; their assets are predicted to expand to $\$ 10$ billion by 1980.62 (It has also been noted that labor unions control enormous amounts of funds in their general treasuries or special

59Dwayne Wrightsman, "Pension Funds and Economic Concentration," The Quarterly Review of Economics and Business,

60 Wrightsman, ibid., p. 29.

61Hanson, Capital Sources and Major Investing Institutions, p. 40 .

62 Chris Welles, "The Unions: \$4 Billion Goes to Work," The Institutional Investor, II (June, 1968), p. 72 . 
accounts, aside from the pension accounts, although there is no public record of how such capital is invested. $)^{63}$

Another vast block of capital--one that overlaps the pension fund category to some extent--is the total assets. of trust companies and bank trust departments. Accurate information on the holdings of these funds is not publicly available, but estimates by the House Banking and Currency Committee run as high as $\$ 250$ billion. 64

Mutual funds and closed-end investment companies have also grow in importance. The mutual funds acquired a net total of $\$ 2.5$ bilition in corporate bonds in the $1957-66$ period and $\$ 9.2$ billion in stocks.65 Combined assets of open and closed-end investment companies totaled about $\$ 25$ billion at the start of 1963.66

Still another growing institutional investor is the diverse group of educational, religious, and charitable foundations. There were an estimated 46,000 foundations and charitable trusts in 1963, compared with fewer than 13,000 in 1952; the 500 largest controlled $\$ 10$ billion in

63 Hanson, Capital Sources and Wajor Irvesting Institutions, p. 41 .

64John Kirk, "A Critical Look at the Institutional Investor," Banking, LX (March, 1968), 13.

65 Homer, "The Impact of Corporate Pension Funds on Equity and Bond Markets," p. 806.

66Hanson, Capital Sources and Major Investing Institutions, p. 24 . 
assets. And to this must be added several billion more in college and university endowment funds. 67

Mutual savings banks had assets of $\$ 46$ billion in 1963; but most of this was in mortgages rather than stocks or bonds. 68 The same general observation, of course, applies to savings and loan associations. Fire and casualty insurance companies, however, purchased $\$ 2.1$ billion worth of corporate bonds and $\$ 4.2$ billion in stocks in the 1957-66 period. 69 Commercial banks make investments on their own account in addition to trust fund investments. The first category of bank investments has not grown, however; in fact, banks disinvested about a milition dollars in funds (mainly from bonds) over the 1957-66 period.70

The unprecedented growth of institutional investors and the aggregate size of their asset holdings are increasing sources of concern to various government officials. The Securities and Exchange Commission, for one, scheduled hearings to start in July, 1968, on the system of brokerage commissions charged institutional investors. 71 But the

$$
\begin{aligned}
& 67 \text { Ibid., pp. } 41,42 . \\
& 68 \text { Ibid., p. } 16 . \\
& 69 \text { Homer, "The Impact of Corporate Pension Funds on }
\end{aligned}
$$
Equity and Bond Markets," p. 806.

70 Homer, ibid., p. 806 .

$7{ }^{1}$ Manuel F. Cohen, "Institutional Investment: Some Current Developments," (New York, May 28, 1968). 
Commission's concern is much broader. Institutional investors now hold an estimated one-third of the securities listed on the New York Stock Exchange, are engaging in a substantial amount of speculative trading (with a serious impact on security prices), are placing a strain on the specialist system, and possess voting power that raises questions about corporate control and privileged investment information-all of which has prompted the chairnan of the Securities and Exchange Commission to call for a "far-reaching economic study of the impact of institutional investors on the securities markets." 72

\section{The Growing Emphasis on Equities and Quasi-Equities}

One of the major concerns of the Securities and Exchange Commission is the growing push by instituional fund managers for so-called "performance"--that is, higher rates of return via greater emphasis on equity investments. This trend obviously has important implications for convertibles, which can often serve as an acceptable way for institutions that have been traditionally rooted to debt securities--by law and/or by policy--to enter the equity market in an indirect manner. Convertibles are, in short, quasi-equity instruments. Pension funds in particular are now heavy buyers of investment grade common stocks and began stepping up their

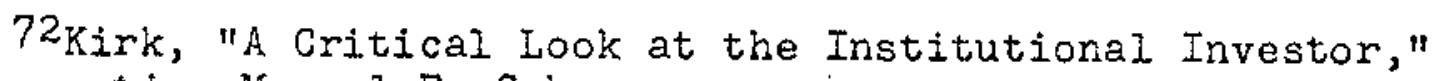
p. 8, quoting Manuel F. Cohen. 
acquisitions of high quality convertibles in the 1950:.$^{73}$ Mutual funds, of course, have always had greater flexibility in this respect. There are a few mutual funds that specialize in convertibles, and many others hold some convertibles in their portfolios. Life insurance companies, armed with their massive purchasing power, are also moving increasingly into the equity or convertible bond markets; here is a case, in particular, where the convertible helps skirt around legal and traditional policies regarding equity investments. Wright Patman, chairman of the House Banking and Currency Committee, is especially alarmed about banks and trust companies, with their gigantic trust fund capital, slipping into the equity markets.74 Hanson states that, "There has been increasing tendency in recent years on the part of states to permit use of the 'prudent man rule' in administering trusts. . .," thus providing the legal basis for the change in investment policy. 75

To some extent, convertible bonds came into prominence specifically as a means of tailoring an equity-type security to the requirements of institutional investors. As Atkinson puts it, "The rise in convertible bond offerings has been a

73Leness, Martin, and Gilmartin, New Money for Business, Techniques of Long-term Corporate Financing, p. 120 . p. 13 .

$74 \mathrm{Kirk}$, "A Critical Look at the Institutional Investor,"

75 Hanson, Capital Sources and Major Investing Institutions, p. 16. 
striking development of postwar bond financing. In part this was a natural development since it was virtually the only way in which equity investments could be sold to a market largely institutional in nature." 76

Wuch of the explosion in new-issue volume of convertibles since 1965 has been absorbed by institutional investors. Institutional purchases in the secondary convertible market have also risen. This is particularly true since late 1966. The reason is that the threatened--and now actual--Federal Reserve margin requirement on convertibles, together with a shrinkage in the availability of margin loans, caused a sharp drop in the level of speculative premiums in secondary market prices. The result, as Ashby Bladen put it, was to. "cancel the former advantages of converts as a speculative vehicle."77 The void in demand was filled, quite rapidly, by bargain-hunting institutional investors--evidence that the secondary convertible market is a highly efficient market in which depressed prices do not go long unnoticed by rational investors. There is every indication that institutional interest in convertibles will contirue at least into the near future. Ralph De Nunzio, executive vice president of Kidder, Peabody and Copany, was quoted in early 1968 as

76 Atkinson, Trends in Corporate Bond Quality, p. 76.

77Ashby Bladen, "Convertible Debentures: An Analyst Finds Many of Them on the Bargain Counter," p. 5. Also see "Convertible Debentures Post Gains of $15 \%$ Since September on Heavy Institutional Buying," Business Week (Dec. 17, 1966), p. 127 . 
saying, "Today, there are more institutions with a weather eye out for equity, and they are more active in the convertible market than ever before. 178 The interviewer added, "Mutual funds, insurance companies and pension funds, it seems, lately have joined the bank portfolio managers who were for years the backbone of institutional trading in 'converts.' Colleges and foundations also are showing new interest."79 An analyst with a large mutual fund, Eaton and Howard, was quoted as saying, "We expect to place greater emphasis on convertibles in the future if interest rates continue high and quality converts (with Moody's ratings of Baa and up) keep coming to market." 80

\section{Shortage of Data on Institutional Volume}

in the Convertible Bond Narket

Specific data on institutional acquisitions and holdings of convertible bonds is sketchy. Table $X$ on the following page shows the findings of the Wharton School of Finance on institutional purchases of convertibles and straight debt issues during the first quarter of 1962.

This table indicates the relative importance of commercial banks and life insurance companies in the primary convertible bond market. It also shows that individuals were still

78 Hershman, "New Style in Convertibles," p. 43.

79 Ibid., p. 43.

80 Ibid., p. 43 . 
responsible for a large volume of convertible purchases in early 1962 ( 55.8 per cent in the period studied), in contrast to the dominance of institutions in the straight debt market (individuals purchased only 9.0 per cent of the straight bonds in the period studied). There has, however, undoubtedly been some shifting in these percentages, commensurate with the recent decline of the convertible as a speculative medium for margin buyers and its rise as a quasi-equity commitment for institutions.

\section{TABLE X}

INSTITUTIONAL AND INDIVIDUAL PURCHASES OF NEW CORPORATE DEBT ISSUES, CONVERTIBLES AND ALL BONDS, JANUARY-MARCH, 1962, AS PERCENTAGES OF TOTAL ISSUED**

\begin{tabular}{|c|c|c|}
\hline Institution & $\begin{array}{l}\text { Convert - } \\
\text { ibles }\end{array}$ & $\begin{array}{c}\text { Ald } \\
\text { Bonds }\end{array}$ \\
\hline 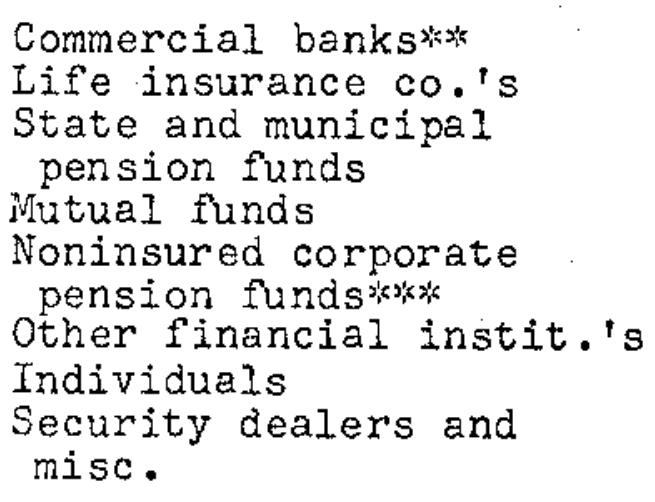 & $\begin{array}{l}20.1 \% \\
11.5 \\
0.0 \\
2.8 \\
0.0 \\
1.6 \\
55.8 \\
8.2\end{array}$ & $\begin{array}{l}34.1 \% \\
14.1 \\
16.2 \\
2.4 \\
2.4 \\
4.9 \\
9.0 \\
16.7\end{array}$ \\
\hline Total & $100.0 \%$ & $100.0 \%$ \\
\hline
\end{tabular}

*Source: Irwin Friend and others, Investment Banking and the New Issues Market (Cleveland, 1967), p. 270 .

***Includes purchases for trust accounts as well as for own account. ***;Excludes bank-administered funds. 
An attempt was made to collect additional and more complete data on the influence of institutions in the primary convertible market by sending questionnaires to the sixtynine largest investment banking houses in the country. These firms account for approximately ninety-seven per cent of total underwriting volume in the United States. Not enough replies were received, however, to justify tabulating the results. The reason given for being unable to complete and return the questionnaire was mainly the unprecedented backlog of paperwork, particularly in the brokerage departments of the firms. This paperwork jam has, of course, received considerable publicity in recent months and is responsible for the Wednesday closings of the leading stock exchanges. 81

Hopefully, the proposed Securities and Exchange Commission study will fill in this data gap in the near future.

\section{Special Types of Convertibles}

There are several special types of convertibles that lie either on the fringes of, or completely outside the bounds of, this study. For the sake of completeness, they deserve brief mention.

There are, for example, a few bonds that are convertible not by indenture provisions, but by warrants; these warrants

81 The questionnaire also contained questions concerning price policy and experience, and on the purchasing of rights on the open market in standby underwritings. 
are detachable in most cases. A regular conversion feature cannot, of course, be sold without selling the bond itself; a detachable warrant can. Often, however, the bondholder is given the right to use the bond itself, at par value, as consideration in exercising the warrant, thus making this type of bond similar to a regular convertible. There are so few of these bonds in existence that they may be either included or excluded in an analysis of convertibles without significantly affecting the results. ${ }^{82}$

Another special type of convertible is one issued to a Small Business Investment Company in return for equity-type funds advanced to a small business. These bonds are normally callable on three months' notice and are convertible at a conversion price based on "sound book value" (per share) of the common stock at the time the bonds are issued, and are generally unsecured. 83 This type of convertible will receive no further attention in this study.

Another class of convertibles lying beyond the bounds of this dissertation is one issued to investors in foreign. markets by United States corporations on behalf of foreign subsidiaries. The bonds are issued in the name of the foreign subsidiary, may be guaranteed by the parent company,

82 For a technical discussion of bonds with warrants, see Graham, Dodd, and Cottle, Security Analysis, 4 th ed., chapters 44, 45, and 46, especially pp. 614, 621 , and 622 .

83 Hanson, Capital Sources and Major Irvesting Institutions, $\mathrm{pp} \cdot 34-37$. 
and are typically convertible into stock of the parent company. Recent volume of such issues has been substantial. Some recent examples include a $\$ 15$ million issues by Genesco, Inc. (issued February, 1968); an $\$ 8$ milizion issue by PlywoodChampion International Finance Company (February, 1968); 84 and a $\$ 77.4$ million issue by LTV International, N. V. (July, 1968).85 One of the main motives behind the sale of such bonds is to circumvent Presidential balance-of-payments restrictions on overseas investments. Hence, these issues are for the most part sold entirely outside of the United States, usually with the assistance of bankers in Europe or elsewhere.

A final special type of convertible is one requiring the payment of a specified amount of cash on conversion, in addition to turning in the bond itself. This type of convertible will receive a limited amount of special attention. From the corporation's viewpoint, such a feature is a way of getting a second, delayed inflow of cash from the issuance of a new convertible. The unpredictable timing of this. second inflow probably accounts for the presence of so few of these issues in the marketplace. (Ashby Bladen found only

84"Effective SEC Registrations," Barron's, XIVIII (Feb. 29, 1968), pp. 906, 907 .

85 The Wall Street Journal, XIII (July 17, 1968), "tombstone" advertisement, p. 15 . 
four issues outstanding as of September, 1966.86 There were five in this researcher's eighty-issue sample, however). Such convertibles are rather interesting from the investor's viewpoint, because they possess a form of built-in leverage, relative to regular convertibles with the same conversion price. ${ }^{87}$ To the extent that the convertible bond market is a perfect market, this advantage will be offset by higher premiums on secondary market prices. Further discussion on this matter appears in Chapters III and IV.

\section{Are Convertibles an Injustice to Existing Stockholders?}

A final question, to be examined very briefly in this chapter, is whether a new convertible is detrimental to the existing stockholders. The charge that convertibles work an injustice on existing stockholders is based on one or more of the following arguments: (1) A group of senior security holders is granted the protection of a creditor and the profit potential of an equity position without, prior to conversion when the newly invested capital is exposed to its greatest risk, having to carry that risk. (2) The eventual conversion of the bond dilutes the per-share equity of the original stockholders. (3) Considering the time value of money, the

86 Ashby Bladen, "A Monetary Approach to the Convertible Bond Market," speech delivered in Philadelphia, Sept. 22, 1966. factor.

87 See Bladen, ibid., for a discussion of this leverage 
corporation can receive greater proceeds from the sale of a straight bond, later calling the bond and replacing it with a common stock issue, than by selling a convertible originally. For example, a straight bond might be sold at par when the common is selling at $\$ 40$ a share, in lieu of selling a convertible with a $\$ 50$ conversion price (convertible into twenty shares). If the common stock rises to $\$ 70$ over, say, a five year period, the bond could be called and twenty shares of common stock issued per bond called; this would net $\$ 1400$, assuming the stock could be sold at the thencurrent market price; allowing $\$ 50$ as a call penalty would still leave $\$ 1350$. On the other hand, a convertible could be sold originally for perhaps $\$ 1200$, assuming the same coupon rate as the straight bond. This $\$ 1200$ includes a premium over par, to be sure, but no additional cash will be received when the bond is converted. The time-adjusted sum of $\$ 1000$ compounded for five years and $\$ 1350$ compounded to perpetuity is greater than $\$ 1200$ to perpetuity.

Those who defend the sale of convertibles point out that (1) Compared with the immediate sale of common stock, the convertible brings in higher initial proceeds and/or causes fewer shares to be added, after conversion, than the number of shares that would have to be sold directly. (2) Relative to an immediate sale of common stock, the sale of a convertible gives the original stockholders the advantage of financial leverage until the bond is converted. (3) A company 
does not rationally raise new capital unless it has a productive use for the new funds; an increased flow of eamings will be available to coincide with conversion of the bond, thus preventing any lasting dilution of earnings or equity. (4) In answer to the third charge advanced by critics of the convertible, the analysis described above ignores the heavy flotation cost of the subsequent stock issue and makes assumptions about selling prices that may not be valid, especially in regard to the selling price of the new common stock issue. Furthermore, whether the timevalued sum of the receipts from sale of the straight bond and subsequent stock issue is greater than the time-valued sum of the receipts from sale of the convertible depends upon the rate of interest assumed in the computation. In the example used, a rate of less than 11.8 per cent would make the straight-bond/common stock combination more advantageous, while a rate of more than 11.8 per cent would make the convertible the better of the two alternatives from the issuer's standpoint. 88

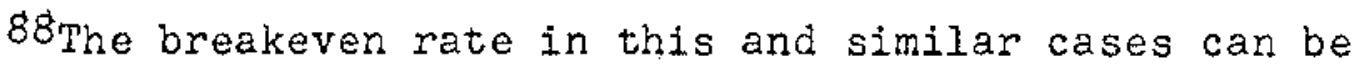
computed by the following general equation. Let $\Sigma_{1}$ represent the compounded sum of the proceeds from the combination. straight/bond/common stock sale and $\Sigma_{2}$ the compounded sum of the proceeds from the sale of a convertible. Then:

$$
\text { And, } \begin{aligned}
& \Sigma_{1}=\left[P_{b}(1+i)^{n}+P_{s}\right](1+i)^{t-n} \\
& \Sigma_{c}(i+i)^{t}
\end{aligned}
$$

in which: 
The argument may not be subject to resolution except on a case-by-case basis. It should be noted, however, that in a perfect security market, no class of investor will get "something for nothing" as it is alleged the convertible purchaser gets. Whether convertible buyers pay a price sufficient to offset any advantage they have over the existing stockholders is an important question. One of the main hypotheses of this dissertation-to be explored in depth in Chapter IV--is that chronic underpricing does exist in

$P_{b}=$ Initial proceeds from sale of straight bond

$P_{S}=$ Additional proceeds from sale of common stock

$P_{c}=$ Proceeds from sale of convertible

$i=$ Interest rate used to compound proceeds

$\mathrm{n}=$ Year (or other time interval) of receipt of $\mathrm{P}_{\mathrm{S}}$

$t=$ Total number of years (or other time period). (It is not necessary to a ssign a value to $t$, though for computational convenience it is assumed here to be finite.)

setting $\Sigma_{1}=\Sigma_{2}$ and solving for $i$ :

$$
\begin{aligned}
& {\left[P_{b}(1+i)^{n}+P_{S}\right](1+i)^{t-n}=P_{c}(1+i)^{t}} \\
& P_{b}(1+i)^{t}+P_{S}(1+i)^{t-n}=P_{c}(1+i)^{t} \\
& P_{S}(1+i)^{t-n}=\left(P_{c}-P_{b}\right)(1+i)^{t} \\
& \frac{P_{S}}{\left(P_{c}-P_{b}\right)}=\frac{(1+i) t}{(1+i) t-n} \\
& \frac{P_{S}}{\left(P_{c}-P_{b}\right)}=(1+i)^{n} \\
& i=\sqrt[n]{\frac{P_{s}}{\left(P_{c}-P_{b}\right)}}-1
\end{aligned}
$$

In the example used:

$$
i=\sqrt[5]{\frac{350}{(1200-1000)}}-1=11.8 \%
$$


the primary convertible bond market. Substantiation of this hypothesis would suggest that both the issuing corporations and their original stockholders are indeed subjected to some degree of injustice.

\section{Summary}

The findings in this chapter can be summarized as follows:

1. Convertibles have a long history; their use in this country has been traced to the early eighteenth century. New issue volume reached substantial proportions during the railroad boom in the nineteenth century. Year-to-year volume in this century has been erratic, ranging from as little as zero (in 1943) to as much as $\$ 4.5$ billion (in 1967). As a percentage of all new bond volume, the volume of new convertibles has been equally erratic, ranging from zero (again in 1943) to 40.3 per cent (in 1929). There is a limited positive correlation between rising stock prices and newissue volume.

2. There are three separate and distinct motives underlying the sale of convertibles by corporations: (a) To "sweeten" debt issues to make them marketable, (b) to effect an indirect and delayed sale of common stock, and (c) to reduce coupon rates in periods of generally high interest rates. There are also several suprlementary motives, including bridging the gap between receipt of new capital and generation 
of earnings sufficient to meet the higher cost of equity. capital and to avoid immediate dilution of stockholders' equity; tapping a segment of the capital market that could not be reached with either a straight bond or a straight stock; to reduce flotation costs; and to appeal to institutional investors.

3. There is a tendency for convertibles to be issued either by relatively small or by relatively large corporations, with a disproportionately light involvement of medium-sized companies. The small companies issue convertibles under the "sweetner" motive; they have little choice about how new capital is raised, are insensitive to relative shifts in cost of capital among different types of securities, and issue convertibles in relatively steady aggregate volume over time. The larger companies issue convertibles under the "indirect sale of stock" motive or to minimize coupon rates in periods of generally high interest rates; these companies invade the convertible bond market at sporadic intervals, thus accounting for erratic fluctuations over time in aggregate new-issue volume, average size of new issues, and the ratio of convertible volume to the volume of straight debt.

4. There has been a trend toward greater diversity in the types of industries issuing convertibles, although the bulk of the issue volume has remained within the broad category of "industrial companies (versus utilities, transportation companies, or financial concerns). 
5. In terms of indenture provisions, convertibles have evolved over the years into a highly homogeneous group of securities, especially in the case of listed convertibles. The typical convertible bond is unsecured, subordinates, convertible without a time delay or time limit (except maturity of the debt itself), has a conversion price that remains fixed over time, is callable on thirty days' or so notice (a feature used to force conversion), contains antidilution provisions, matures in twenty to twenty-five years, and has a highly illusory sinking fund provision.

6. The default risk on convertibles has been greatly exaggerated. With the exception of the experience of the $1920^{\prime} \mathrm{s}$, in fact, the default rate on convertibles has been lower than on nonconvertibles, at least in the prewar portion of this century. There is need for a new, more meaningful rating system for convertibles, one that is tailored to the special nature of convertible bonds.

7. The influence of institutional investors has grown to enormous proportions, both in the convertible bond market and in the security markets in general. Institutions promise to continue their growth into the future. Because of their role as quasi-equity instruments, convertibles enable institutions bound by legal and traditional ties to debt securities, to acquire equity-type securities. These observations contain important implications for the marketing of new convertible issues and for pricing of convertibles in the secondary market. 
8. There are several special types of convertibleswincluding bonds convertible via warrants, convertibles sold to Small Business Investment Corporations, and convertibles sold overseas by United States companies on behalf of foreign subsidiaries. In addition, there are convertibles requiring an additional cash payment on conversion; this special type of convertible will receive some individual attention in the following two chapters.

9. To the extent that new convertibles are underpriced in the primary market, the charge that they cause injustice to original stockholders possesses some validity. Whether underpricing does, in fact, occur in the primary convertiole market is the subject of Chapter IV. Before proceeding to the analysis of the primary convertible bond market, however, it is necessary to establish--as a reference point--the degree of pricing perfection prevailing in the secondary convertible market. This is accomplished in the following chapter. 


\section{CHAPTER III}

\section{DIRECI COMMITMENTS IN CONVERTIBLES}

The explorations of this chapter center on the first of the two major hypotheses underlying this dissertation. This first hypothesis is that the secondary convertible bond market (in contrast with the primary convertible market) is a nearly perfect market in which alternative rational investment or hedging techniques will produce approximately equal returns and returns not significantly different from those obtainable by ordinary investment in common stocks after making allowances for differences in utility between risk-averting and risk-seeking investors. Various techniques involving direct commitments in convertibles are investigated in this chapter. The rates of return produced by these techniques are compared with overall rates of return on direct commitments in common stock and, on a somewhat less rigorous basis, with average realized yields on straight bonds. The term "direct commitments" is used to distinguish the investment techniques examined in this chapter from the special hedging techniques examined in Chapters $V$ and VI.

It was not hypothesized that alternative investment techniques would produce precisely equal returns. Comparing convertibles as a group with common stocks as a group, some 
differences in realized rates of return should stem from relative concentration of commitments in stocks by riskseeking investors and a greater concentration in convertibles by risk-averting investors. This influence was described in Chapter $I$. Whether it actually affects realized returns is one question to be answered in this chapter. The comparison with realized yields on straight bonds has been included to shed further light on this matter.

Internally, within the category of convertible bonds itself, realized returns will differ among various investment techniques to the extent that the techniques themselves are irrationally constructed.

Both internaliy and externally, further variations in realized returns will occur to whatever extent the hypothesized perfection in the market is less than complete. For one thing, it was expected that breaking the category of convertibles down into subgroups would lead to variations in return not evident at the group level. Carried to an extreme, for. example, one would hardly expect to find equal returns among individual convertibles. The question is, how far can one progress from the group level toward the individual level before the hypothesized perfęction in the convertible market can be declared to have lost its validity? An attempt has been made in this chapter to provide at least a partial answer. Other sources of imperfection undoubtedly exist as well, the task being to either prove or disprove that they are 
relatively minor compared, for example, with imperfection existing in the primary market.

It is possible to devise an almost unlimited number of investment strategies within the general category of "direct commitments." The really basic alternatives, however, are limited. There is, first of all, a reasonably clear distinction between a "buy-and-hold" strategy and a "trading" strategy. Secondly, it can be assumed that the investor makes commitments on either a selective or a nonselective basis: Nonselective refers to either investment in all issues in a population of securities or in a random sample of that population. And, thirdly, one can assume either margined or nonmargined commitments by the investor. The various strategies investigated in this chapter by no means exhaust the full range of possible strategies; but enough variations are covered to provide meaningful answers regarding the degree of perfection in the convertible bond market and the average rates of return available in that market.

How to Analyze Convertibles

Before proceeding to the analysis, it should perhaps be pointed out that not every researcher would agree that convertibles should be analyzed to any depth as a separately defined class of security. Graham, Dodd, and Cottle, for example, say:

A privileged senior issue, selling close to or above face value, should meet the requirements either of a straight fixed-value investment or of an attractive common-stock commitment, and it should be 
bought with one or the other qualification clearly in view. . The investor interested in safety of principal should not abate his requirements in return for a conversion privilege; the speculator should not be attracted to an enterprise of mediocre promise because of the pseodo-security provided by the bond contract. . Our opposition to any compromise between the purely investment and the admittedly speculative attitude is based primarily on doubt as to whether the purchaser is psychologically prepared for the adventure. When he takes an intermediate stand, the result is usually confusion, clouded thinking, and selfdeception. The investor who relaxes his safety requirements to obtain a profit-sharing privilege is frequently not prepared, financially or mentally, for the inevitable loss if fortune should frown on the venture. The speculator who wants to reduce his risk by operating in convertible issues is likely to find his primary interest divided between the enterprise itself and the terms of the privilege, and he will probably be uncertain in his own mind as to whether he is at bottom a stockholder or a bondholder.1

An analyst following this advice would logically divide convertibles into two distinct categories, those of "investment" quality on the one hand, and those of "speculative" quality on the other. This is true, at least, if the analysis is intended to be directly useful to "investors" and "specu-. lators" for decision-making purposes.

There is undoubtedly some merit in what these authors say. Any investigation of convertibles would be incomplete without looking at subgroups within the general category of convertible bonds. It is suggested, however, that convertibles do represent a unique and highly homogeneous class of security,

1Graham, Dodd, and Cottle, Security Analysis, 4th ed., 
one that deserves separate analysis. It is not satisfactory to force convertibles into analytical molds designed for stocks and straight debt issues. 2 Nor is it possible to draw a sharp distinction between an "investor" and a "speculator" on this basis. As for the "psychology" involved, it is meaningless to insist that a risk-averting investor simply ignore a conversion feature or to treat it as "incidental" as the authors recommend. 3 Nor is it appropriate to insist that a risk-seeking individual simply ignore the downside cushion provided by a convertible's intrinsic value, because this feature will probably have an effect on both expected and realized return on investment. When an investor (or a speculator) buys a convertible, he is not buying a straight bond, nor a common stock. He is acquiring a convertible and all of the characteristics and propensities peculiar to a convertible as a unique type of security.

Thus, it is regarded as not only proper, but preferable, to begin the analysis by treating convertibles as a distinct class of security. This in no way prohibits, nor diminishes the usefulness of, a further analysis of subgroups within the general population of convertibles.

2It is appropriate to recall here the problems, discussed in Chapter II, caused by the use of straight-bond standards in assigning agency ratings to convertible bonds. p. 605 .

3 Graham, Dodd, and Cottle, Security Analysis, 4th ed., 
Rates of Return in a Buy-and-Hold Strategy

The technique analyzed in this section is a buy-and-hold, nonselective strategy. Specificaliy, an attempt was made to measure the average rate of return--as a per cent per annum compounded annualy--resulting from direct commitments in all of the convertible issues in a sample believed to be representative of the convertibles outstanding during the period from January, 1956, to July, 1968. The sample used was the eighty-issue sample described in Chapter II, less three issues which were originally sold over-the-counter. A list of the issues in the sample is shown in the appendix.

\section{Methodology}

Mid-month closing secondary market prices for January and July were recorded for each issue, beginning with the mid-January, 1956, price or the first mid-January or midJuly price quoted thereafter, and ending with the last mid-January or mid-July price quoted up to July, 1968.4 As is true of the general population of convertibles, many of the issues in the sample were forced into conversion via exercise of the call feature. Furthermore, there were almost as many starting dates as there were issues. This meant that a buy-and-hold strategy was, more accurately, a strategy involving numerous sales and reinvestments in new convertibles

4 North Texas State University microfilm files, the Wall Street Journal. 
(the conversion privilege not being exercised at any time). This is precisely the real-life situation facing the investor, however, so no attempt was made to skirt around this complication. Of the seventy-seven total issues in the sample, the greatest number outstanding at any one time was forty$\operatorname{six}$.

An effort was made to make the average rates of return directly comparable with those reported by Lawrence Fisher and James H. Lorie on common stocks listed on the New York Stock Exchange.5 In particular, the desired comparison was with the average rates obtainable, without reinvestment of dividends, by a tax-exempt investor, making allowance for brokerage commissions, with initial investments measured in terms of total required cash commitments and ending values measured in terms of market values of the ending portfolios. 6 As Fisher and Lorie point out, numerous other arrangements are possible (some eighteen tables were required to report all of the possibilities they investigated). Probably the most debatable aspects of the particular arrangement chosen are the assumptions of tax-exemption and nonreinvestment of dividend income (or interest income in the case of convertibles). Both were selected to effect a slight simplification in what proved nevertheless, to be very laborious and time

5 Fisher and Lorie, "Rates of Return on Investments in Common Stocks, the Year-by-Year Record, 1926-1965."

6Ibid., Tabie 2, Part A. 
consuming computations. Only minor differences in average rates of return are traceable to reinvestment versus nonreinvestment of dividend or interest income. For example, the Fisher and Lorie tax-exempt rate for the period beginning in December, 1955, and ending in December, 1965, was 12.5 per cent with reinvestment of dividends and 12.2 per cent without reinvestment of dividends. 7 The reason for the small differences is that reinvestment of dividends means a larger investment base on which subsequent compounded rates are computed; the amount of the dividends does not simply accrue to the benefit of past cash investments. The taxexemption assumption is, needless to say, not so minor a matter. It can be defended, however, on the grounds that approximate ex post adjustments could be made in the rates of return on convertibles, particularly with the aid of the comparable Fisher and Lorie tables covering taxable commitments in stocks. ${ }^{8}$ More importantly, however, meaningful conclusions regarding the degree of perfection in the convertible bond market can be drawn on the basis of relative rates of return, without recourse to absolute rates, by treating the tax factor as a constant.

Although the rate-of-return computation was similar to the Fisher and Lorie approach, there were some differences.

7 Ibid., Table I, Part A and Table 2, Part A. and $E$.

Ibid., Table I, Parts $C$ and $\mathrm{E}$; and Table 2, Parts $\mathrm{C}$ 
First, the Fisher and Lorie computations covered various periods from December to December, while the present study covers January and July beginning and ending dates. The sixmonth interval, rather than the one-year interval, was chosen in order to gauge with greater precision the variations in rates of return among various intervals defined in terms of peaks and troughs in the stock market. The use of December market prices was avoided in order to eliminate the influence of any so-called "tax selling." Hence, the January/July price points. The mid-January price points, however, correspond to the Fisher and Lorie end-of-December price points with only a half-month lag and are, for all practical purposes, comparable for several time periods with ending dates through 1965.

Secondly, the "turnover" of funds invested in convertibles is greater than in common stocks because of the relatively brief life of many convertibles. Fisher and Lorie did encounter cases in which common stocks were delisted from the New York Stock Exchange. The basic procedure they followed in such cases was to assume an over-the-counter sale of the stock and a reinvestment of equal dollar amounts in all remaining stocks on the exchange, with a brokerage commission associated with only one "dummy" stock, however, being charged against the transaction.9 The procedure followed in the 
present study was slightly different. When a convertible was called, the assumption was made that all bond holdings were sold and an equal number of dollars reinvested in remaining convertibles, including any new convertibles that coincidentally appeared: in the sample at the same time point. The same complete-liquidation-and-reinvestment procedure was followed in cases where new convertibles appeared without a coincidental termination of an old one. The investment was charged, however, only with the brokerage commission associated with reinvestment in one new convertible in each case, not with the reinvestment over all remaining convertibles.

Except for these slight simplifications, however, the rates of return in the present study are directly comparable to the Fisher and Lorie rates. One of the basic features of the Fisher and Lorie analysis was incorporated in the present study. Given the choice between investing in an equal number of shares of each security or investing an equal number of dollars in each security, the latter was selected in order to better simulate random selection by the investor. In addition to the average rates of return on convertibles in the 1956-68 period, the average rates of return on the matching common stock were al so computed. The basic procedure was the same as that followed on the convertibles. Appropriate adjustments were, of course, made for stock splits and stock dividends. 
Twenty different beginning and ending points within the 1956-68 period were selected. The objective was to provide a measure not only of average rates of return over the entire period, but of realized returns associated with four different types of beginning and ending-point combinations: Peak-to-peak, trough-to-trough, peak-to-trough, and trough-to-peak, all as defined by the Dow-Jones Industrial Average at the mid-January and mid-July time points. Unfortunately, few of the Fisher and Lorie rates are well suited to this purpose; but the closest possible comparison was made in each case.

\section{Results of the Analysis}

The results of the analysis are summarized in Table XI. Looking first at the return figures for the entire period, the average rate on convertibles with a beginning point of January, 1956, and an ending point of July, 1968, was 6.38 per cent; this compares with 8.42 per cent for the common stocks matching the convertibles.10 Since the Fisher and Lorie study was updated only through the end of 1965, the rates for the period from January, 1956, to January, 1966, were computed for comparison with the Fisher and Lorie rate for December, 1955, to December, 1965. As shown in the table,

10The beginning and ending points were examined to be sure no distortion in the rate of return measurement was caused by starting near a market peak and ending near a trough, or vice-versa. A straight line connecting the two selected time points in a graph of monthly Dow-Jones Industrial Averages closely approximates a "least-squares" line. 
易

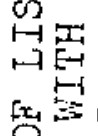

Fx, [1 $\infty^{n+x}$

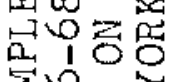

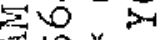
3 L क人 00 적ㄷㄹ D

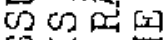
C) 10 에

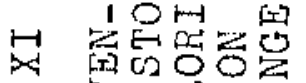

$\rightarrow \overrightarrow{0}{ }^{-1}$

驺口国完

क 1 日至与

政

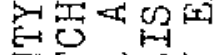

西叫出

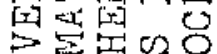

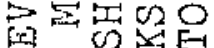

netoo

3 政

O 列o

经点

勿出

바분

जि

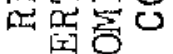

동용

릉

$\pi 0$

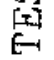

壱

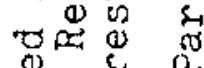

$0+0$

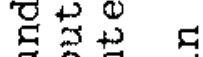

오

D.

in o

잉

Es 0 品

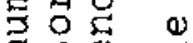

I +10 勿

4

\&若

مि

कि

$+4$

㐘

$\circlearrowleft \underset{0}{4}$

क⿺⿻一⿰冫⿰亅⿱丿丶丶⿱⿰㇒一乂

E

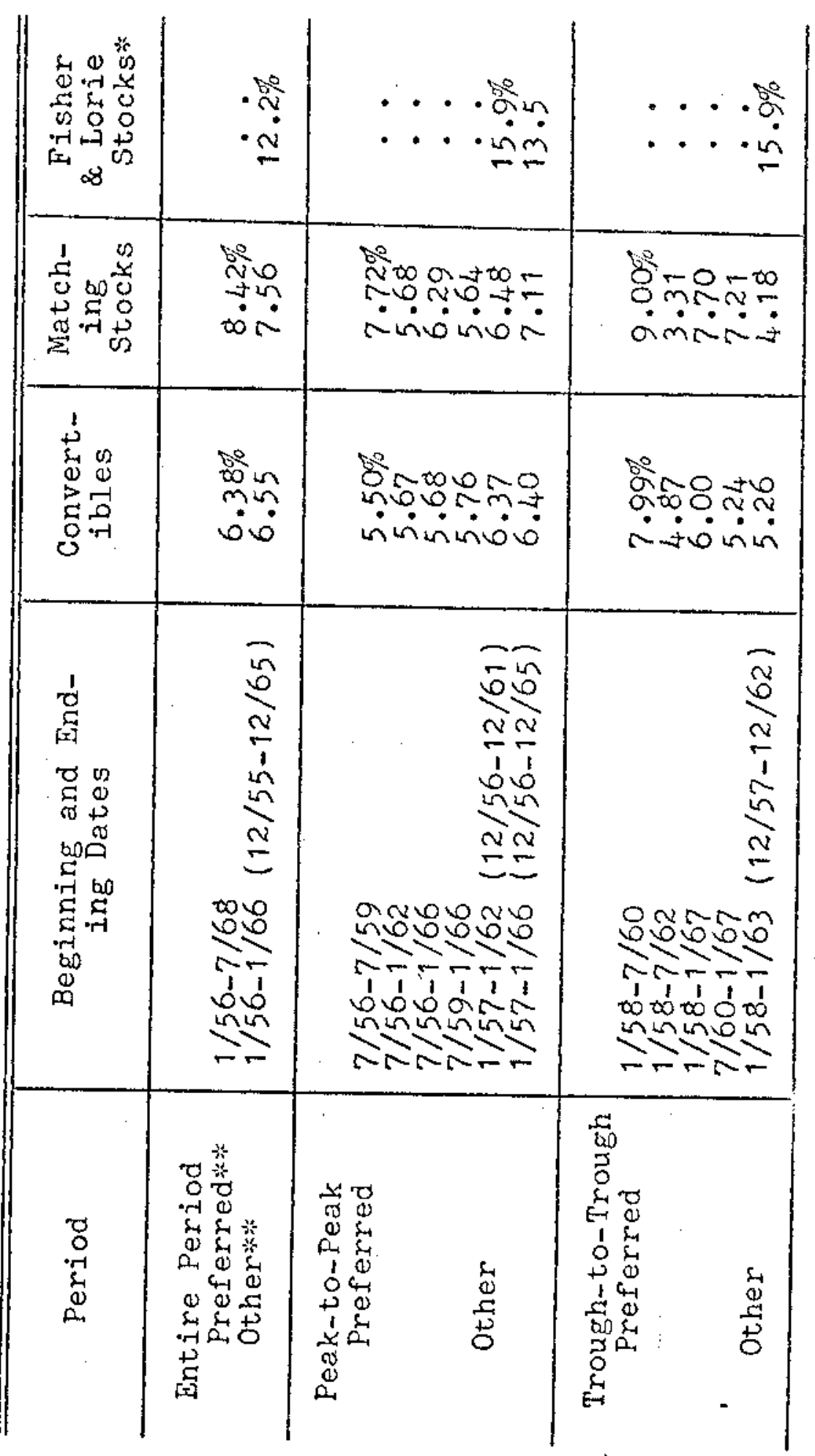




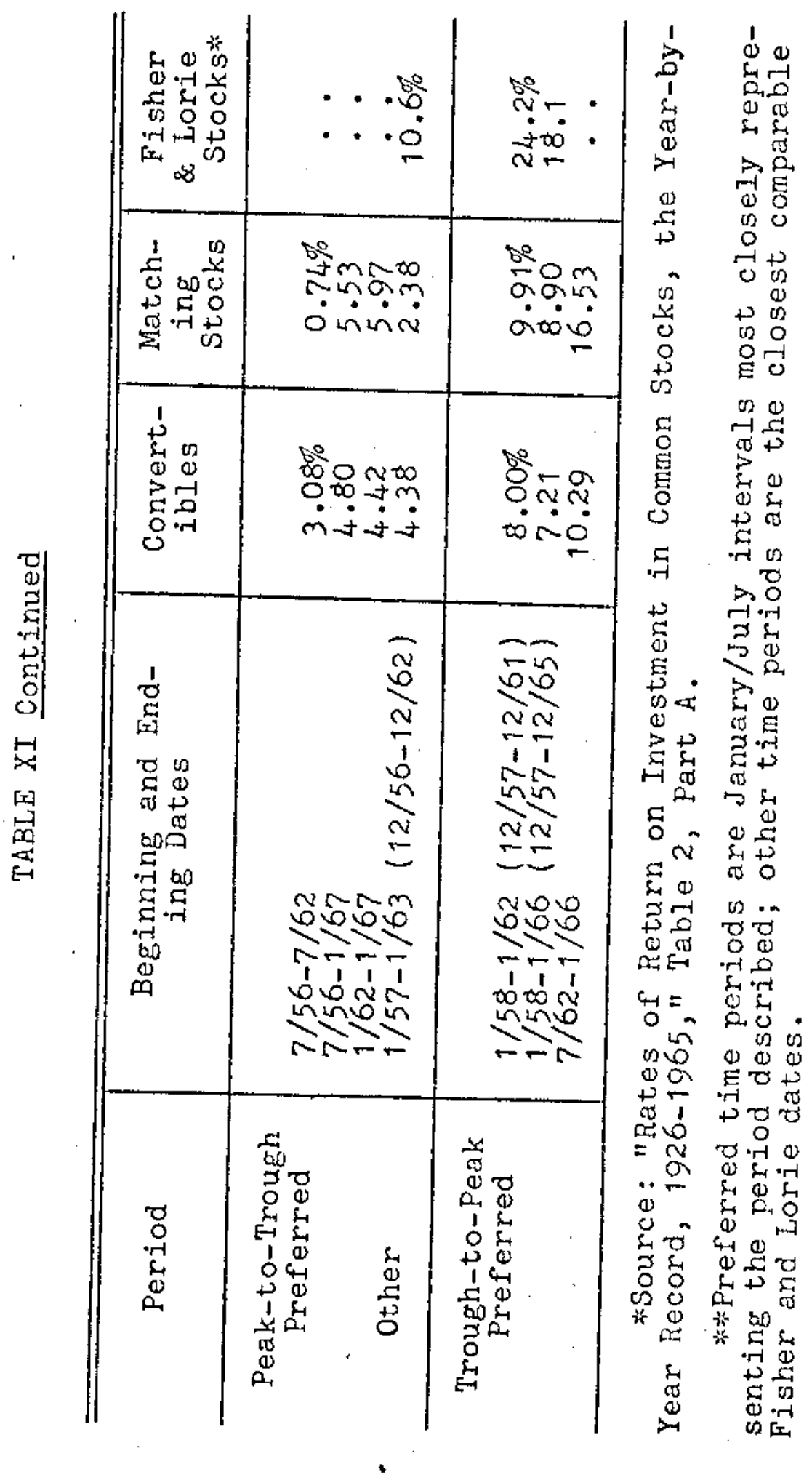


these rates are $6.55,7.56$, and 12.2 per cent for convertibles, stocks matching the convertibles, and all stocks on the New York Stock. Exchange, respectively. ${ }^{11}$ This same general pattern is evident, with a few exceptions, throughout the other return figures shown. That is, the convertibles generally produced a return a percentage point or two below the matching stocks, and the matching stocks produced a rate substantially lower than the full range of stocks on the New York Stock Exchange ( 4.6 percentage points less over the entire period through January, 1966).

Realized returns on straight debt issues have, of course, been lower since 1956 than either the 6.38 per cent or the 6.55 per cent rates on convertibles, particularly in view of the substantial erosion in bond prices over the period. 12 Although one can only speculate about the average rate of return on convertibles over a longer time span than that covered by the present study, it is highly probable that the

${ }^{11}$ Interestingly, the average return over the 1955-65 period on CREF (College Retirement Equities Fund) is reported to have been 13.5 per cent, or close to the Fisher and Lorie rate. See Charles G. Stokes, "The Future of Variable Annuities," The Institutional Investor, I (March, 1967), 25.

12 The precise effect of the decline in bond prices cannot be determined without specifying the exact pattern of investments and reinvestments over the period in question. The full inpact of the decline in bond prices would have fallen on an investor commiting all of his funds at the beginning of the period. An investor who spaced out his purchases, however, would have been affected less because of purchases at declining prices (or, to use the alternate measures, acquisition of securities with higher yields-to-maturity and higher current yields). 
same ranking of rates would occur--that is, the lowest rate on straight bonds, a higher rate on convertibles, a stilI higher return on the stocks matching the convertibles, and the highest return on the general population of stocks. The available evidence indicates long-term averages of approximately 5 per cent for straight debt and 7.5 to 9.5 per cent for common stocks.13 If the relationship disclosed by the present study holds over the very long-run, convertibles and their higher-yielding matching stocks could be expected to fall somewhere in between.

What is the most plausible explanation of the rate stmucture observed in the study? The difference between the average rate on convertibles and the rate on the stocks matching the convertibles can be explained by (1) The tendency for risk-averting investors to concentrate commitments more heavily in convertibles rather than in the matching stocks, in order to take advantage of the downside cushion

13 Nicholas Molodovsky estimated the average before-tax return on the Standard and Poor's Index and its predecessors for the period 1871-1959 to be 7.5 per cent; see "Stock Values and Stock Prices," The Financial Analysts Journal, XVi (MayJune, 1960), 81 . The Fisher and Lorie rate, comparable to those referred to in the present study, for the period January, 1926, to December, 1965, was 7.3 per cent; reinvestment of dividends, however, boosted the rate to 9.3 per cent; see "Rates of Return on Investment in Common Stocks, the Year-by-Year Record, 1926-1965," Table 1, Part A and Table 2, Part A. The long-run estimate of 5 per cent for straight bonds is for the period $1900-43$ and was based on data on file at the National Bureau of Economic Research; see Harold $G$. Fraine and Robert H. Mills, "Effect of Defaults and Credit Deterioration on Yields of Corporate Bonds," The Journal of Finance, XVI (Sept., 1961), 433. 
commonly associated with convertibles. Such investors both expect and are satisfied with a lower return in exchange for reduced market risk and perhaps reduced interest-rate risk. Realized yields on convertibles will drop accordingly-through a combination of lower income payments by the issuer and a bidding up of market prices by purchasers. (2) Market imperfections. One source of imperfection affecting the realized yields on convertibles and their matching stocks during the period studied has to do with the availability of margin loans. Until the recent change in Federal Reserve. margin requirements, speculators were able to obtain up to eighty or ninety per cent in loans on convertibles but were restricted to considerably less on stocks. This created an artificial increase in the demand for convertibles and an artificial decline in demand for the matching stocks. That is, the convertibles were purchased as an indirect method of speculating, with thin margin, on the stocks. Since the rates of return in the study were computed on the implicit assumption of normargined commitments, 14 the realized return on convertibles was destined to be lower than on the matching stocks, other factors remaining the same. Aside from this

14 Margined buying is not normally associated with buyand-hold investment strategies. Hence, rates of return based on use of margin were not computed. Many of the rates on convertibles in Table XV are less than, or not much greater than, the interest that would have been paid on borrowed funds. Thus, the use of margin, even if feasible procedurally, would have been questionable as a profit-seeking investment strategy. 
known source of market imperfection, however, it is reasonable to conclude that the first explanation, rather than market imperfection, accounts for most of the observed spread between the average rate of return on convertibles and the return on the convertible-matching stocks.

The larger spread between the average return on the matching stocks and the return on the full range of stocks on the New York Stock Exchange can be explained by (1) A relatively greater number of less promising companies among the issuers of convertibles than among the general population of corporations with listed stocks on the New York Stock Exchange, causing a lower realized return on the convertible-matching stocks through a combination of declines in market prices (or smaller increases) and lower dividend payments. Such companies would be those associated with the "sweetener" motive discussed in Chapter II. It was concluded in that chapter, however, that the "sweetener" motive has been stressed too heavily by casual observers. One should be equaliy careful not to overemphasize the importance of this factor in explaining differences in realized rates of return. To the extent that this factor is a cause of the rate spread, however, it reflects imperfections in the market, because in a perfect market original prices would have been bid downward in the case of less promising companies so as to equalize subsequent rates of return. Logically, a rational nonrandom selection of convertibles would produce a somewhat larger 
return than random selection. (2) The fact that convertibles whose matching stocks rise in price tend to be converted within a relatively brief period of time, while those whose matching stocks decline in price or remain stable tend to remain unconverted. This is particularly true in cases where the convertible was issued to effect an indirect sale of stock and when the company can force conversion via a call provision. As was indicated in Chapter II, the call feature is everpresent, and the "indirect sale of stock" motive is probably the dominant reason for sale of new convertible issues. The net effect is that a sample of outstanding convertible issues will contain a disproportionate number of companies whose stocks are depressed either because of business problems or because the stocks have gone "out of fashion" in the stock market. The seventy-seven-issue sample used in the present study was such a sample of outstanding convertibles. It was reasonably representative of the general population of listed convertibles from which an investor would have selected commitments, but was not representative of the general population of listed common stocks. The matching stock of a convertible chosen at random is likely, in short, to be less promising than a stock chosen at random from among the full group of listed stocks. This condition reflects both irrationality of technique and market imperfection. (3) Other market imperfection. It is probable that some of the difference between the average rate on convertible-matching stocks and 
stocks in general is attributable to miscellaneous market imperfections. Such things as imperfect knowledge or irrational behavior on the part of investors undoubtedly Influence realized return figures in all security markets. But it seems reasonable to conclude that the market imperfections described in (1) and (2), along with the sampling bias in (2), are the main contributors to the return spread between convertible-matching stocks and listed stocks in general.

As far as the relationship between listed convertibles as a class and listed stocks as a class, then, the general hypothesis that a high degree of perfection characterizes the secondary markets was not fully verified. The spread between the realized rate of return on convertibles and the rate on matching stocks is in line with original expectations and is not attributable, for the most part, to market imperfection other than the known imperfection stemming from past differences in Federal Reserve margin requirements. The wide gap between the rate on matching stocks and the rate on all common stocks listed on the New York Stock Exchange, however, denotes a somewhat greater degree of imperfection. The implication, from the investor's viewpoint, is that unless some way can be found to rationally select convertibles or convertible-matching stocks on a nonrandom basis, higher realized returns, relative to risk, are available in the general population of listed stocks. 
Turning now to the other rates shown in Table $X I$, as might be expected the peak-to-peak and trough-to-trough rates are not greatly different in most cases from the entireperiod rates; there was a slight but not highly significant widening in both of the rate spreads just discussed. The peak-to-trough rates readily reveal the greater resistance of convertibles to downward movements, compared with their matching stocks; investors who willingly forfeited profit potential for downside protection were not disappointed, provided the comparison is made with the stocks matching the convertibles. Comparison with the general population of listed stocks, however, raises questions again about the rationality of nonselective commitments in either the convertibles or the matching stocks; relative to the entire-period rates, the shrinkage in the Fisher and Lorie rate is smaller in both absolute and relative terms than in the convertible rate or the matching stock rate. And, clearly, the trough-to-peak rates demonstrate that convertibles are a bad bargain in a rising stock market. Direct investment in the matching stocks -or better still, direct investment in the general population of stocks--would have resulted in higher realized returns. The main reason is that the rise in convertible prices is partly offset by a shrinkage in speculative premiums; this phenomenon is investigated in Chapter V. Estimating the probability of a rise rather than a sideways movement or a decline in the market once one leaves the realm of historical 
data is, of course, another matter entirely and one that has not been explored in this dissertation.

\section{Selective Strategies}

Can realized rates of return on convertibles be improved by following some selective strategy rather than choosing convertibles at random or investing in all issues of a representative sample? It has already been suggested that rational nonrandom selection of convertibles or their matching stocks would produce a larger return than random selection becauseof the tendency for the population of convertibles to be disproportionately weighted with less promising companies or matching stocks. Some nonrandom selection procedure to eliminate this bias would be desirable. Sticking, however, with the general population of listed convertibles, are there subgroups or subclassifications of convertibles that will produce higher rates of return, on average, than the general population of convertibles?

It was not feasible in the present study to compute rates of return on various subgroups for direct comparison with the rates shown in Table XI. Two short-cut measures were designed, however, to shed some light on this question. Both were applied to the seventy-seven issues in the sample, subcategorized in various ways. The first, which might be referred to as a "highest-profit measure," consisted of computing the dollar profit resulting from investment in each 
convertible at the lowest recorded price preceding the highest recorded price. It is, in other words, a measure of the profit an omniscient investor could have earned by seling out at the highest price recorded over the period of the study, having bought at the lowest price prior to the point of sale. It is by no means suggested that such a performance could be duplicated by any investor. The measure is designed to provide relative, not absolute information. The dollar profit figures were converted to noncompounded annual rates. Brokerage commissions, interest received, and tax considerations were all ignored.

The second measure is the average recorded market price of each convertible, obtained by adding up the mid-month. prices for each issue and dividing the total by the number of entries. The logic of this measure is that issues with a rising trend over the long-term, or with wide though erratic ranges in price, will have higher average prices than other issues and thus have greater inherent profit potential. No specific reference is made in either measure to a buy-or-hold versus a trading strategy. Neither strategy is precluded and neither is required. Inferences regarding this variable could be drawn in some cases, however.

It was believed that both of these measures, interpreted together, would provide strong clues, if not firm conclusions, on the relative profit potential of subgroups of convertibles. The various subgroups to which these measures were applied 
are shown in Table XII, along with the two measures in each case. The first breakdown is in terms of the average number of common shares involved in the conversion privilege. Since conversion terms often change after issuance of a convertible (because of a desire on the part of corporate management to accelerate conversion or because of anti-dilution provisions in the indenture), an average of beginning and ending number of shares was used. Except for the first category of 10 to 17.99 shares, the two measures taken together indicate a tendency for issues with a larger number of shares involved in the conversion feature to possess relatively more profit potential than those involving a smaller number of shares. The high 31.9 per cent highest-profit percentage in the 10 17.99 group is attributable to an unusually brief time span involved in converting the dollar profit to an annual percentage- -1.7 years versus a range of 2.3 to 3.1 years for the other groups. There is no way to determine if this time difference is significant or merely a chance occurrence. If. the latter is assumed, the percentage might be adjusted to something between 17.5 per cent (corresponding to 3.1 years) and 23.6 per cent (corresponding to 2.3 years). To the extent that this is a legitimate adjustment, it strengthens the positive correlation between number of shares in conversion and relative profit potential. There is a very plausible explanation for such a relationship. Convertibles with a large number of shares in the conversion feature are, virtually 
TABLE XII

HIGHEST-PROFIT AND AVERAGE-PRICE MEASURES

APPLIED TO SUBGROUPS IN THE SEVENTY -

SEVEN-ISSUE SAMPLE OF LISTED

CONVERTIBLES

\begin{tabular}{|c|c|c|c|}
\hline Category & $\begin{array}{l}\text { No. of } \\
\text { Issues }\end{array}$ & $\begin{array}{l}\text { Highest- } \\
\text { profit } \\
\text { Measure'k }\end{array}$ & $\begin{array}{l}\text { Average- } \\
\text { price } \\
\text { Measure }\end{array}$ \\
\hline $\begin{array}{l}\text { Average No. of Shares in } \\
\text { Conversion**; } \\
10-17.99 \\
18-25.99 \\
26-33.99 \\
34-41.99 \\
42-49.99 \\
50 \text { and over } \\
\text { Cash features }\end{array}$ & $\begin{array}{l}11 \\
25 \\
16 \\
13 \\
4 \\
3 \\
5\end{array}$ & $\begin{array}{l}31.9 \% \\
13.4 \\
14.9 \\
33.0 \\
24.3 \\
54.1 \\
30.9\end{array}$ & $\begin{array}{l}\$ 1191 \\
1139 \\
1112 \\
1598 \\
1363 \\
1485 \\
1176\end{array}$ \\
\hline $\begin{array}{l}\text { Moody's Rating }{ }^{x_{2} x_{k} x_{k}} \\
\text { Aa } \\
\text { A } \\
\text { Baa } \\
\text { Ba } \\
\text { B } \\
\text { Not rated }\end{array}$ & $\begin{array}{r}1 \\
5 \\
22 \\
40 \\
6 \\
3\end{array}$ & $\begin{array}{l}2.3 \% \\
28.2 \\
21.6 \\
23.5 \\
22.1 \\
39.7\end{array}$ & $\begin{array}{r}\$ 1276 \\
1328 \\
1157 \\
1297 \\
1208 \\
1170\end{array}$ \\
\hline $\begin{array}{c}\text { Rights vs. Straight Issues } \\
\text { Rights issues } \\
\text { Straight issues }\end{array}$ & $\begin{array}{l}43 \\
34\end{array}$ & $\begin{array}{l}28.5 \% \\
13.9\end{array}$ & $\begin{array}{r}\$ 1302 \\
1148\end{array}$ \\
\hline $\begin{array}{l}\text { Industrial Category } \\
\text { Industrials } \\
\text { Public Utilities } \\
\text { Transportation } \\
\text { Bankirg and Finance }\end{array}$ & $\begin{array}{r}64 \\
5 \\
5 \\
3\end{array}$ & $\begin{array}{l}19.4 \% \\
14.2 \\
55.4 \\
39.7\end{array}$ & $\begin{array}{r}\$ 1178 \\
1583 \\
2129 \\
1170\end{array}$ \\
\hline $\begin{array}{l}\text { Original Bond Price in High- } \\
\text { est-profit Measure } \\
\text { Below } \$ 1000 \\
\$ 1000 \text { or above }\end{array}$ & $\begin{array}{l}30 \\
47\end{array}$ & $\begin{array}{l}26.9 \% \\
20.5\end{array}$ & $\begin{array}{r}\$ 1123 \\
1335\end{array}$ \\
\hline
\end{tabular}

Noncompounded annual percentages.

$*$ Average of beginning and ending figures.

$x^{\prime} x_{k} *$ At date of issuance or shortly thereafter; taken from Moody's Manuals. 
by definition, those whose stocks are lower-priced. Lowpriced stocks tend to move more erratically in the stock market, in terms of percentage changes. Hence, the price of the convertible also moves erratically, but with a more"onesided fluctuation due to the downside "floor" provided by the bond's intrinsic value. This does not mean that a buyand-hold strategy over the long-run will necessarily produce a return greater than on convertibles whose stocks are in the higher-price range. But it does mean, at least, that larger profits are available over briefer time periods.

Issues with cash-payment conversion features did not possess any clear-cut advantages over issues with regular conversion terms. This suggests that the leverage effect associated with such issues was fully compensated for by price movements immediately following sales in the primary market:

In the categorization by Moody's ratings, if allowances are made for the very small number of issues in the Aa and "not rated" categories (especially after referring to the more stable average-price figures), there appears to be virtually no significant variation of profit potential among the ratings. It will be found in the following chapter that an inverse correlation exists in the primary convertible bond market. (See pages 156-58). This source of imperfection is evidently eliminated quite rapidly in initial secondary trading. 
One of the most surprising discoveries was that convertibles originally marketed via rights offerings to stockholders possessed relatively greater profit potential in subsequent secondary trading, as indicated by the third category in Table XII. A propensity for investors to bid up the price of rights issues relatively more than straight issues in initial secondary trading is noted in Chapter IV (pages 156, 157). The present evidence suggests that even higher prices were justified on the basis of subsequent price movements of rights issues in the secondary market. One possible explanation for the disparity in relative profit potential between rights issues and straight issues is that the population of straight issues tends to be disproportionately represented by less promising companies whose stockholders were disenchanted with future prospects, thus making a public offering of the new convertible issue necessary. Stronger companies, whose stocks and convertibles perform well in the secondary market, are able to sell new convertible issues through rights offerings. This explanation must be regarded as an unverified hypothesis, however. The data is not sufficient to draw definite conclustons.

In terms of industrial categories, the transportation and perhaps the banking and finance groups in the sample tested showed more profit potential than the industrials or public utility companies. There is serious doubt, however, whether this finding is much more than an accident of time and 
circumstances. The high figures in the transportation category, for example, are traceable to a few airline issues. Projecting such differences in profit potential into the future is a tenuous procedure.

A final breakdown was made on the basis of the price of each issue at the time the hypothetical investment was made in the highest-profit measure. The purpose of this grouping was to see if an investor wolld have been better off restricting his commitments to issues selling below some absolute level-- $\$ 1000$ in this case. In the below-\$1000 group, the average purchase price was $\$ 897$, while in the $\$ 1000$-or-above group the average purchase price was $\$ 1103$. The two measures appear at first glance to have produced conflicting results. The average-price measure, however, is not meaningful in this case because the difference in average starting price injects automatic bias into the average-price computation. Restricting the interpretation to the highest-profit measure, it was found that the issues originally selling below $\$ 1000$ had significantly greater profit potential than the higherpriced issues. The average profit on the lower-priced issues was $\$ 675$, with a holding period of 2.8 years, while the average profit on the higher-priced issues was $\$ 541$, with a holding period of 2.4 years. As will be explained more thoroughly in Chapter $V$, there is a tendency for changes in speculative premiums to exert a varying influence on price performance of a convertible, depending upon the initial price 
of the bond relative to either intrinsic value or conversion value. For this reason, the results of the profit potential measurements in terms of original bond price were not obvious or easily predictable. In addition, one writer indicates that convertibles with conversion values at or below intrinsic values tend to have relatively dim future prospects. ${ }^{15}$ Since the below-\$1000 issues in the sample must contain more of such issues than the $\$ 1000$-or-above group, a prediction based on this statement might be in conflict with the results just described.

In summary, then, it has been found--subject to the limitations posed by the two measuring devices--that the degree of perfection in the convertible bond market deteriorates somewhat as one moves from the general population of convertibles to various subgroups. Specifically, there is a tendency for issues convertible into a large number of shares to be more profitable than issues convertibles into a smaller number of shares, for issues originally marketed through rights offerings to be more profitable than straight issues, and for lower-prices issues to be more profitable than higher-priced issues. On the other hand, differences in Moody's ratings or industrial category did not seem to have a meaningful effect on profit potential. 


\section{Trading Strategies}

Instead of following a buy-and-hold strategy, or attempting to find subsegments of the convertible market that are more profitable than the general population of convertibles, any number of different short-term trading strategies could be followed. Three such strategies were tested in the present study to see if above-average returns could be generated. An abbreviated sample of twenty convertible issues was used to test these strategies. The twenty issues were selected to be as representative as possible of the seventy-seven-issue sample in terms of such variables as agency ratings, year of issuance, and conversion terms. Instead of relying on January and July prices, however, mid-month prices for all months of the year were recorded.16

The first strategy was based or the discovery, discussed in the preceding section, that lower-priced issues appeared to be more profitable than higher-priced issues. The trading mule employed was to hypothetically buy one $\$ 1000$-denomination convertible anytime a recorded mid-month price was below $\$ 1000$, except that a minimum interval of six months was allowed to pass after each purchase before making another purchase of the same convertible. Four different seliing rules were tested: Selling the is sue when the recorded secondary market price reached $\$ 1000$, when it reached $\$ 1100$, when

16 North Texas State University microfilm files, The Wall Street Journal. 
it reached $\$ 1300$, and when it reached $\$ 1500$. If these target prices were not reached, the issue was sold at the end of two years at the market price prevailing at that time. Amounts received as interest income were added to the trading profits, al lowance for brokerage commissions was made, and overald time-adjusted annual rates were computed on a noncompounded basis. The results are shown in Table XIII. Transactions not terminated as of July, 1968, were excluded from the tabulations.

TABLE XIII

RESULTS OF TRADING STRATEGY \#1

(Noncompounded Annual. Rates)

\begin{tabular}{|c|c|c|c|c|}
\hline \multirow{2}{*}{ Category } & \multicolumn{4}{|c|}{ Target Price } \\
\hline & $\$ 1000$ & $\$ 1100$ & $\$ 1300$ & $\$ 1500$ \\
\hline $\begin{array}{l}\text { Average holding period } \\
\text { in months }\end{array}$ & 10.98 & 16.96 & 21.67 & 22.84 \\
\hline $\begin{array}{l}\text { Average annual return } \\
\text { Nonmargined } \\
80 \% \text { margin } \\
50 \% \text { margin } \\
20 \% \text { margin }\end{array}$ & $\begin{array}{l}7.4 \% \\
:: \\
:\end{array}$ & 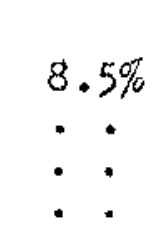 & $\begin{array}{l}9.0 \% \\
: \vdots \\
\therefore\end{array}$ & $\begin{array}{l}9.9 \% \\
10.9 \\
13.8 \\
25.5\end{array}$ \\
\hline
\end{tabular}

The return figures in Table XIII can be compared directly with the 6.38 per cent buy-and-hold rate shown in Table XI for convertibles, and somewhat less directly with the 8.42 per cent on matching stocks and the 12.2 per cent on all New York Stock Exchange stocks. The strategy is rational in the 
sense that it improved on the 6.38 per cent return produced by the buy-and-hold strategy. The use of leverage via margined buying would expand the percentage returns even more. With an assumed interest rate of 6 per cent on borrowed funds, the 9.9 per cent return in Table XIII increases to $10.9,13,8$, and 25.5 per cent with 80,50 , and 20 per cent of the purchase price advanced as margin, respectively. Internally, within the convertible bond market itself, market imperfections must exist in order for such higher returns to be possible. It should be realized, however, that the strategy is irrational in the sense that returns proportionately greater than the additional risk involved are probably available among the general population of stocks listed on the New York Stock Exchange.

The second strategy consisted of buying each issue at every six-month interval, regardiess of the price, and selling out on the basis of a moving stop-loss rule. Specifically, a sale would be made if the recorded convertible price declined ten per cent or more from any successive high (or from the purchase price in the event of a steady decline in price). This strategy was based on the familiar concept of "cutting losses short" and "letting profits run." Nonterminated transactions were included in the tabulation on the basis of market value at mid-July, 1968. As in the first strategy, appropriate allowances were made for interest received and brokerage commissions paid. Some 239 transactions 
were included in the computation, 129 of which produced a loss and 110 a gain. The average holding period was 13.67 months. The overall average rate of return, on a nonconpounded annual basis, was 6.9 per cent with nonmargined commitments, 7.2 per cent with 80 per cent margin, 7.9 per cent with 50 per cent margin, and 10.7 per cent with 20 per cent margin. The 6.9 per cent compares directly with the 6.38 per cent buy-and-hold rate in Table XI and is obviously not materially better than the latter rate. Relative to the first trading strategy, therefore, this one must be declared irrational. Nor does it contribute to the quest for a measurement of the degree of perfection prevailing in the secondary convertible bond market.

The third strategy is based on the observation that convertible bond prices are significantly influenced by changes in the level of speculative premiums. This change is a two-dimensional phenomenon. On the one hand, the magnitude of speculative premiums on individual convertibles will rise or fall in a pattern correlated with changes in prices of the matching stocks and with the conversion terms of the bonds; this aspect is examined in depth in the next chapter. The other dimension has to do with general increases or decreases in the level of speculative premiums stemming from external sources, such as availability of loans for margin speculation or increases in the cost of such loans. If the external forces are temporary in nature, if one could 
construct a general index to track the level of speculative premiums, and if one could pick the low and high points on. that index on an ex ante basis, above-average trading profits might be possible. The most difficult stumbling block in such a strategy is construction of the speculative-premium index. The task is greatly complicated by two factors: first, the fact that convertibles tend to be relatively shortlived, creating an unstable environment for sampling purposes. And, secondly, because it is extremely difficult to eliminate the influence of general changes in stock prices; that is, the two dimensions of the speculative-premium phenomenon are difficult to separate other than on a conceptual basis. For the third trading strategy tested in the study, a speculative-premium index was constructed on the basis of the speculative premiums occurring on half of the twenty convertibles in the sample. This required estimation of intrinsic values at each monthly time point, the estimation being made by using standard present-value tables, along with actual maturities of each bond at each monthly time point, coupon interest amounts, and prevailing interest rates as reported by Moody's for the appropriate risk categories. ${ }^{17}$ Computation of conversion values at each monthly time point was also required. This was done by determining the conversion feature of each bond at each monthly time point and

17From "Special Features" section of Moody's Industrial Manual, 1967, and from Moody's Bond Survey, Vol. $60,1968$. 
applying that information to the corresponding stock prices. Given these conversion values and intrinsic value, it was then possible to determine the speculative premiums by reference to the market values of the convertibles at each time point. No attempt was made to adjust for the influence of stock price changes on the level of speculative premiums, the problem discussed above. Because few of the issues extended ali the way back in time to the 1956 starting point, the index constructed by totaling the speculative premiums and computing averages was not considered reliable prior to about 1959. The index from 1959 through early 1968 is shown in Figure 2.

The difficulty in constructing even this "impure" index on a very small sample of issues provides some indication of the complexity involved in deriving and maintaining general indexes designed to facilitate a trading strategy based on changes in the level of speculative premiums.

The third trading strategy in the present study was based on the assumption that a trader could have picked the low and high points in the graph of Figure 2--obviously an optimistic and probably unrealistic assumption. Hypothetical purchases and sales were made at three sets of time points: a purchase at mid-October, 1960, and a sale at mid-December, 1961; a purchase at mid-March, 1965, and a sale at midDecember, 1965; and a purchase at mid-March, 1966, with a subsequent sale at mid-December, 1966. In each purchase, 


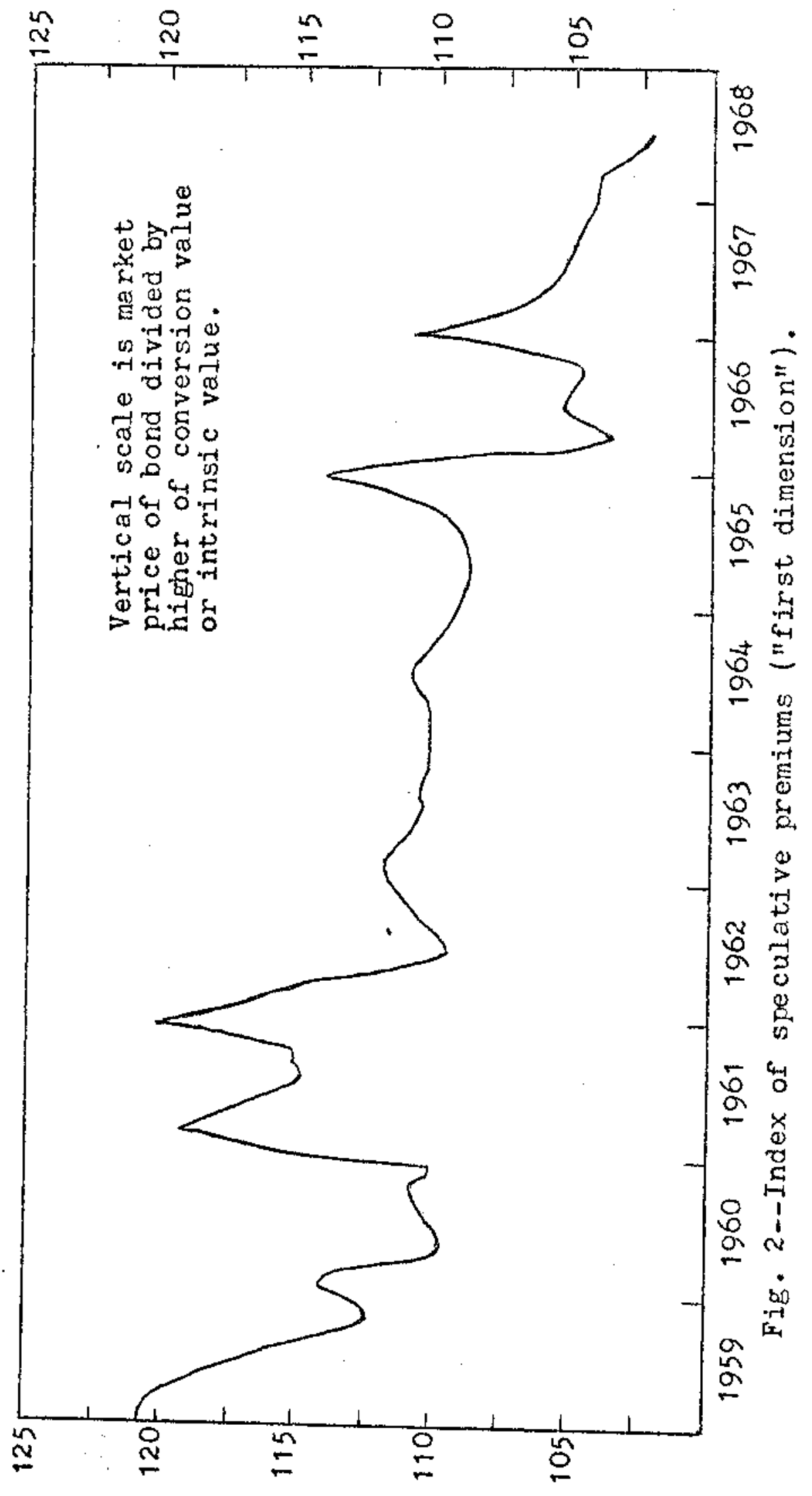


investments were made in an equal number of certificates of all convertibles in the twenty issue sample, that is, those that were outstanding at the various buying points. As in the previous trading strategies, allowances were made for interest received and commissions paid, and noncompounded annual rates were computed. The results are summarized in Table XIV. A six per cent interest rate on margin loans was again assumed.

TABLE XIV

RESULTS OF TRADING STRATEGY \#3

(Noncompounded Annual Rates)

\begin{tabular}{|c|c|c|c|c|}
\hline \multirow{2}{*}{ Category } & \multicolumn{4}{|c|}{ Trading Period } \\
\hline & $\begin{array}{l}\text { Oct.,' } 60- \\
\text { Dec., } 161\end{array}$ & $\begin{array}{l}\operatorname{Mar}, 165- \\
\operatorname{Dec}, 165\end{array}$ & $\begin{array}{l}\text { Mar.,' } 166- \\
\text { Dec., } 166\end{array}$ & $\begin{array}{l}\text { Over- } \\
\text { all }\end{array}$ \\
\hline $\begin{array}{l}\text { Average holding } \\
\text { period in months }\end{array}$ & 14.00 & 9.00 & 9.00 & 10.03 \\
\hline $\begin{array}{l}\text { Average annual re- } \\
\text { turn } \\
\text { Nonmargined } \\
80 \% \text { margin } \\
50 \% \text { margin } \\
20 \% \text { margin }\end{array}$ & $\begin{array}{c}16.3 \% \\
. \\
.\end{array}$ & $\begin{array}{c}17.8 \% \\
\cdot . \\
\cdot . \\
.\end{array}$ & $\begin{array}{l}1.8 \% \\
:: \\
:\end{array}$ & $\begin{array}{l}11.4 \% \\
12.7 \\
16.6 \\
32.4\end{array}$ \\
\hline $\begin{array}{l}\text { Change in Dow-Jones } \\
\text { Industrial Avg. }\end{array}$ & $+23.9 \%$ & $+6.1 \%$ & $-14.2 \%$ & $\cdot$ \\
\hline
\end{tabular}

Although the overall rates of return are substantial, It is difficult to draw any conclusions regarding the rationality of the strategy or the implications concerning 
the degree of perfection in the secondary convertible bond market because of the uncontrolled influence of changes in stock prices. The validity of this observation can be determined by simply examining the return produced in the March, 1966-December, 1966, trading period when the stock market declined 14.2 per cent as measured by the Dow-Jones Industrial Average. It is significant, of course, that a profit of any size was earned in this period. Even after deducting from the 1.8 per cent an allowance of 3.3 percentage points for bond interest received, the net loss of 1.5 per cent was much less than the 14.2 per cent decline in stock prices. Some further allowance, however, must be made for the fact that some of the resistance to decline in the convertible prices was attributable, not to the trading strategy, but to the fact that intrinsic values acted to cushion losses. Nor do the results in the first two trading periods add clarity to the analysis. In one case the rise in stock prices is greater than the profit produced; in the other it is less.

Thus, the third strategy must remain, at the limits of the present investigation, a deductively-derived approach with possible merit, but lacking empirical verification. And, as was true of the second trading strategy, little else of a conclusive nature was learned about the degree of perfection in the secondary convertible bond market. 
The results produced by the first trading strategy, however, are sufficient to warrant the conclusion that enough imperfection exists internally within the seconcary convertible bond market so that rates of return significantly greater than those obtainable by a buy-and-hold strategy can be generated by employment of a rational trading strategy. The imperfection, however, does not begin to approach that prevailing in the primary convertible market, as will be shown in Chapter IV.

Summary and Conclusions

The following is a summary of the findings of this chapter:

1. Over the 1956-68 period, the average rate of return on listed convertibles resulting from a nonselective buy-and-hold strategy in the secondary convertible market was 6.38 per cent per annum compounded annually, assuming tax-exemption and no reinvestment of interest income, with allowance made for brokerage commissions. The comparable return on the stocks matching the convertibles was 8.42 per cent. The closest comparable return reported by $F$ isher and Lorie for all stocks listed on the New York Stock Exchange was 12.2 per cent. 18 Peak-to-peak and trough-to-trough measurements within this overall time period produced only minor differences from these rates in most cases. Peak-to-trough rates revealed the

18 Fisher and Lorie, "Rates of Return on Investment in Common Stocks, the Year-by-Year Record, 1926-1965," Table 2, Part A for the period Dec., 1955-Dec., 1965. 
advantages of convertibles, relative to their matching stocks, in a declining market; but there was no advantage over listed stocks in general. Trough-to-peak rates clearly substantiated the thesis that convertibles are less profitable than common stocks in a rising market.

2. The spread between the average entire-period rate on convertibles and the comparable rate on the stocks matching the convertibles is attributable mainly to differences in utility between risk-seeking and risk-averting investors rather than to market imperfection, the main exception being imperfection associated with Federal Reserve margin requirements on stocks and convertibles, respectively, during the period studied.

3. The larger spread between the average entire-period rate on the convertible-matching stocks and all stocks listed or the New York Stock Exchange is attributable to a combination of built-in bias in the sampling technique used in the study, and market imperfections. Random selection from among the general population of listed stocks would have produced a larger return than random selection from among the population of convertible-matching stocks. And, by implication, rational nonrandom selection of convertibles or convertiblematching stocks would have produced a larger return than random selection of convertibles or convertible-matching stocks.

4. Internally, within the general population of listed convertibles, the degree of perfection in the market 
deteriorates somewhat in moving down to various sublevels. Specificaliy, issues convertible into a larger number of shares of stock tend to be more profitable than issues con-. vertible into a smaller number of shares; convertibles originally sold through rights offerings tend to be more profitable on the secondary market than straight issues; and issues bought below some absolute price level $(\$ 1000$ in the study) tend to be more profitable than higher-priced issues. On the other hand, differences in Moody's ratings or industrial category did not appear meaningful. Nor did the presence of a cash-payment provision in the conversion feature. The measuring techniques used to determine the profit potential of the subgroups possessed only limited potency, however, and further researci would be appropriate.

5. Of three short-term trading techniques tested, one was irrational and one produced inconclusive results. One, however, produced a return ranging from 9.9 per cent on nonmargined commitments to 25.5 per cent on 20 per cent margin. This technique is rational in that it successfully took advantage of internal imperfections in the secondary convertible bond market. But it is irrational in the sense that greater returns, relative to risk, are available via investments among the general population of listed stocks. The technique producing inconclusive results was based on use of an index of changes in the general level of speculative premiums; while the approach continues to possess deductive 
validity, the attempt at empirical verification was not successful.

6. Although a moderate degree of imperfection exists both internally within the secondary convertible bond market (as evidenced by the rational trading strategy and by the subgroup comparisons) and externally relative to the general market for listed stocks, much of the observed variation in rates of return is traceable to risk/utility differences. There was an unmistakable pattern of rising average rates of return correlating directiy with rising risk as one moves from straight bonds to convertibles and, finally, to listed common stocks. The degree of imperfection in the secondary convertible market is sufficiently moderate to warrant using that market as a reference point for measurement of imperfection prevailing in the primary convertible bond market--the subject of the next chapter. 
CHAPTER IV

\section{IMPERFECTION IN THE PRIMARY CONVERTIBLE BOND MARKET}

The hypothesis regarding the primary convertible bond market was that the primary market is an imperfect one in which original issue prices tend to be chronically below prices prevailing in initial secondary trading, thereby providing opportunity for substantial profit. This hypothesis stands in direct contrast to the one pertaining to the secondary convertible bond market.

An important implication of the primary market hypothesis is that funds which should move from investors to the issuing corporations are diverted to speculators or others operating between the primary and secondary markets. In real as distinct from monetary terms, economic resources which, barring market imperfection, would be attracted to productive employment must move to such use, if at all, via some medium other than the primary convertible bond market. An additional implication is that the cost of debt capital to corporations is increased.

This chapter is divided into three main sections: A description of the marketing system for new convertibles; an analysis and presentation of empirical evidence to 
substantiate the hypothesis; and the development of an explanatory theory, that is, an attempt to explain why underpricing exists in the primary market and why extraordinary profits are attainable through speculative market operations.

\section{The Marketing System for New Convertible Issues}

There are three basic ways to market a new convertible: Through a public offering, on a privileged subscription basis to existing stockholders, or via private placement. Except for small issues, investment bankers virtually always participate in public offerings; they often provide negotiating services in private placements; and they almost always furmish standby underwriting, as needed, in privileged-subscription offerings .

An understanding of these alternative marketing methods is basic to interpretation of empirical evidence on primary market pricing and to development of a theory to explain underpricing in the primary market.

\section{Volume and Advantages of Private Placement}

While the data on the volume of private placements is not always precise, enough evidence exists to conclucie that slightly less than half of the dollar volume of all new debt offerings (both convertible and nonconvertibie) in the postwar period reached initial buyers via private placement for direct placement as it is often called). Atkinson, for 
example, reports that 43.9 per cent of the dollar volume of all types of bonds was placed directly during the 1944-65 period, based on data from Moody's Bond Survey and the Investment Dealers' Digest. ${ }^{1}$ Comparable Securities and Exchange Commission data indicate a 50.0 per cent ratio for offerings in the $1948-65$ period. 2 This agrees with the findings of the wharton School study. 3 The large volume of private placements has been largely a postwar phenomenon. In the 1900-43 period, only about seven per cent of all new bond issues was directly placed. It is also clear that debt, rather than equity, instruments account for the great bulk of private placements.

Certain types of bond issues, notably utility and railroad issues, cannot be privately placed because of legal restrictions. If these issues are eliminated from consideration, the portion of debt issues placed privately rises to something significantly over half. A Securities and Exchange Commission study covering the $1948-51$ period indicates the portion to be about seventy per cent. 4 No

1 Atkinson, Trends in Corporate Bond Quality, p. 106. 2 Ibid., p. 96.

3 Friend and others, Investment Banking and the New Issues Market, p. 28 .

4Securities and Exchange Commission, Privately-Placed Securities--Cost of Flotation, p. 6. Also see Friend and others, Investment Banking and the New Issues Market, pp. 192, 349 . 
comparable data on more recent years, or specifically for convertibles, were encountered.

Although complete data on private placements of convertibles are not readily available, there is evidence that a considerably smaller percentage of the new convertibles issued is privately placed than is the case for bonds in general--probably less than fifteen per cent in the postwar period. 5 This is attributable largely to pre-emptive rights requirements on new convertible issues. Some private placement of convertibles is undoubtedly voluntary, however, and the percentage placed privately may have risen with the recent upsurge of institutional interest in convertibles.

The substantial volume of private placements of debt instruments stems from certain advantages this marketing method possesses: Sale of the issue is often easier and faster; private placement circumvents some of the guesswork associated with unstable securities markets; registration with the Securities and Exchange Commission and public disclosure are avoided; flotation cost is often less; 6 and the terms of the indenture may be less rigid because of the ability to regotiate changes with institutional or other holders of the issue. Avoidance of registration and disclosure

5 Atkinson offers some evidence along these lines; Trends in Corporate Bond Quality, p. 86.

6 Securities and Exchange Commission, Privately-Placed Securities-- Cost of Flotation, pp. 1-10. 
requirements of the Securities and Exchange Commission is undoubtedly the main reason for the difference in relative volume of private placements before and after the 1930's. But another important stimulus to private placements has been the rising demand from institutional investors, who have provided a ready narket for private placements. Finally, smaller companies in particular have of ten found it more feasible to place debt issues privately than to undertake a public sale, as indicated by the fact that privately sold issues have, over the years, been consistently smaller in average size than publicly marketed issues.?

There are, of course, some disadvantages of private placement, including the possibility that terms of the indenture will be more restrictive than in a public offering, and the inability of the corporation to retire the issue via open market purchases.

It is estimated that investment bankers perform a negotiating function in about fifty to sixty per cent of all private placements. ${ }^{8}$ The remainder is, of course, sold. directly by the issuing corporation to the private purchaser.

\section{Privileged Subscriptions}

A privileged offering of a convertible bord to stockholders is a marketing device that lies, in a manner of

7 Friend and others, Investment Banking and the New Issues Market, pp. 343,344 .

I Ibid., p. 9 . 
speaking, somewhere between a private placement and a fullfledged public offering. In many cases, a privileged offering of a convertible is required by pre-emptive right. In a study of twenty-three convertibles issued publicly (that is, other than by private placement) in the 1948-52 period, Pilcher found that a pre-emptive right made a privileged offering mandatory in forty-eight per cent of the cases, the pre-emptive right being required by state law or by corporate charter or articles of incorporation. In the remaining fifty-two per cent, management was free to choose the marketing method. In this latter group, about twenty per cent of the managements voluntarily chose a privileged offering. 9 Broman, in his 1949-59 study, found that a third of the public issues involved privileged subscriptions, again with a substantial portion representing voluntary choice on the part of management. 10

In the twenty-nine-issue sample of convertibles described in the preceding chapter, excluding four issues on which the marketing method was not determinable or involved a special exchange of securities (such as in a merger), 44.0 per cent of the issues reached the market via rights offerings. In

9Pilcher, Raising Capital With Convertible Securities, pp. 97-100. A matching study of convertible preferred stock issues, involving a larger and more reliable sample, agreed closely with these findings on convertible issues.

10 Broman, "The Use of Convertible Subordinated Debentures by Industrial Firms 1949-59," pp. 68, 69. 
the eighty-issue sample, excluding three special exchanges, 55.8 per cent of the issues involved rights offerings. Synthesizing all of this data, it is evident that roughly half of the convertibles sold publicly in recent years involved rights offerings, mostly because of legal requirements but voluntarily in a significant portion of the issues.

The greatest advantage of a rights offering from the corporation's viewpoint is, of course, the existence of a group of investors already "sold" on the company. Where the rights offering is not required by state law or corporate charter, moral obligation may compel management to use the privileged subscription offering. An additional stimulus may arise from the fact that if future equity financing is anticipated, a satisfied stockholder group is a desirable asset.

There is no assurance, however, that the stockholder group will absorb the entire offering. The convertible, being a different, albeit similar, type of security from a stock, may not appeal to some stockholders. In theory, such stockholders can sell their rights and recover whatever value they possess. As will be demonstrated later in this chapter, the tendency is for at least some stockholders to sell out too cheaply, with speculators and others acquiring the rights on the open market at bargain prices. If the rights offering is not fully subscribed by either the stockholder group or 
by open market purchasers of the rights, an investment banker typically "stands by" to market the balance of the issue to the general public or to institutional buyers.

\section{Straight Public Offerings}

By elimination, it appears that roughly a fourth of all new debt issues, or a half of all public las distinct from privately placed) debt offerings, reaches the market through straight public sales (the other half being through rights offerings). In the case of convertibles specifically, roughly forty per cent of all new issues, and, again, fifty per cent of the non-private issues are sold through straight public offerings. For the larger issues, an investment banker is almost always involved in the marketing operation. Although competitive bidding is still the rule in utility and railroad issues, and although "best efforts" underwriting is still used on some small issues, the great majority of larger industrial issues offered directly to the general investing public reaches the market through regular negotiated underwriting. In 1967, about thirty-two per cent of the dollar volume of new offerings of all types of securities was marketed via competitive bidding. 11 This represents only a small change from Pilcher's 1955 estimate of 27.6 per cent. ${ }^{12}$ The

11 Computed from data in Investment Banker-Broker Almanac, 23 rd annual ed. (New York, 1968), pp. 6-15. p. 134 .

12 Pilcher, Raising Capital With Convertible Securities, 
percentage is higher for corporate bonds (as distinct from all securities), but lower for convertibles specificaliy. No data on the frequency of "best efforts" underwriting was encountered; but an interview with a Dallas investment banking executive elicited the comment that "best efforts" arrangements are "almost a thing of the past." 13

The significance of these observations is that the discussion of convertibles in the remainder of this chapter can, except for utility or railroad issues, be narrowed down for all practical purposes to the three main marketing methods: (1) Private placements, which probably account for less than twenty per cent of the dollar volume of all new convertible issues; (2) rights offerings, accounting for roughly forty per cent; and (3) straight negotiated underwritings, accounting for roughly forty per cent of the total. Furthemore, while private placements, as such, are not beyond the scope of this dissertation, it was not possible to collect accurate empirical evidence regarding pricing practices in private placements. Hence, the remainder of this chapter concerns only the eighty per cent or so of the volume of convertibles marketed publicly.

13John $W$. Turner, manager of underwriting department, Eppler, Guerin and Turner, Inc., interview, Dallas, Texas, June 9, 1968. 
The Marketing Procedure in

Straight Underwritings

The marketing procedure for straight negotiated public offerings must be sharply distinguished from that used in rights offerings. In straight offerings, the general procedure followed by the underwriters and issuing corporations. can be outined as follows:

1. The issuing corporation and an underwriter form an agreement, largely informal in nature, for the latter to act as managing underwriter of the new issue.

2. A registration statement is filed with the Securities and Exchange Commission. Registration is required of all interstate security issues except those specifically exempted (mainly minicipal, bank, and railroad issues; government debt instruments; issues of less than $\$ 300,000$, that recuire only a "short form" registration under Regulation $A$; and private placements).14 The Securities and Exchange Commission currently takes from forty-five to sixty days before it declares the registration to be "effective;" in past years, this interval was about twenty days, the change being attributable to a backlog stemming from increased new-issue volume. During this registration period, the Securities and Exchange Commission notifies the corporation and the managing underwriter of any deficiencies in the application.

14 Ernest W. Walker, Essentials of Einancial Management (Englewood Cliffs, N. J., 1965), p. 197 . 
3. Immediately after the registration statement has been filed with the Securities and Exchange Commission, the managing underwriter begins to assemble the underwriting group that will participate in the issue on a risk-bearing basis. Each prospective underwriter "within a day or two is expected to indicate whether or not he is willing to accept the underwriting position offered to him."15 Some additional comments on the formation of underwriting groups appears later in this chapter. "At the same time the managing underwriter begins to receive preliminary 'indications of interest' from investment dealers who will help to retail the issue [on a nonrisk-bearing basis]. These dealers, which may include members of the underwriting group, are sometimes referred to as the 'selling group.'116

4. Until the registration statement has been declared "effective" by the Securities and Exchange Commission, the bond issue cannot technically be offered to prospective buyers by the underwriting syndicate. Prospective buyers are, however, sent a tentative or "red herring" prospectus. This is particularly true of prospective institutional buyers. The tentative prospectus contains virtually all information the final prospectus will contain, except for the offering price and the underwriting commission or "spread." The price blocks

15Leness, Martin, and Gilmartin, New Money for Business, Techniques of Long-term Corporate Financing, p. 64 .

16 Ibid., p. 65. Phrase in brackets added. 
provided by the printer are left blank on the tentative prospectus. In addition, the other information in the tentative prospectus is subject to changes requested by the Securities and Exchange Commission. Despite the technical restriction on sales of the security issue prior to final approval by the Securities and Exchange Commission, the underwriters receive "indications of interest"--tentative orders, in effect-from institutional or other large prospective buyers, based on the "red herring" prospectus and on tentative price information conveyed informally to the prospective' purchasers. The line between "offering" the security and soliciting an "indication of interest" is obviously thin and is a source of continuing concern to the Securities and Exchange Commission and to the parties who stand potentially in violation of the Secutities Act. It is * important to note, at this point, that both the offering price and the underwriting commission are only informally set and are subject to change within the constraints set by a stringent "code of honor" in the investment banking community. During the registration period, the managing underwriter is committed, typically, only to a range within which offering price and underwriting spread, respectively, will probably be set. The "indications of interest, meanwhile, provide an important feedback on market demand at the contemplated offering price, and a guide as to whether that price will have to be lowered in order to market the entire 
issue. ${ }^{17}$ The ability to raise a tentative price is, by the nature of the marketing process and the part of the rigorous. "code of honor" which governs investment banker contacts with prospective buyers, much more limited.

5. The marketing arrangement, tentative at the start, firms up as the registration period progresses. Near the end of the registration period, the managing underwriter, armed with the "indications of interest" from large buyers and from retailing dealers who hope to participate in the offering, meets with the issuing corporation to set the final offering price and underwriter spread. The official cortract signing takes place immediately upon final approval (effective registration) by the Securities and Exchange Commission, some forty-five to sixty days after initial registration. Normally, both the underwriting agreement between the managing underwriter and the issuing corporation, and the formal agreement among the members of the underwriting group itself, will be signed within a day after the date of final approval by the Securities and Exchange Commission. The printer, operating on a round-the-clock basis if necessary, adds the official offering price to the prospectus so that the final prospectus will be rapidly available to prospective buyers of the new issue.

6. In the typical case, the public offering officially begins on the day following final approval by the securities 
and Exchange Commission, sometimes late on the same day. Then, as members of the Merrill Lynch underwriting department put it:

If the deal is successful, it is normally spoken for within a few hours. If part of the issue is still unsold after a week or two, the group will usually elect to "break" the price to a level at which the securities can be sold, thus freeing their capital for other issues. Some firms, however, make a practice of holding unsold securities for longer periods in anticipation of improved market conditions.18

The Wharton School study indicated that the ratio of average month-end inventories to average monthly public sales of new issues was only nine per cent for all types of corporate bonds in the January-March, 1962, period.19 To the extent that this ratio is representative of other time periods, it is apparent that underwriters have a very small backlog of unsold bonds-less than three days' worth of sales on average--and hence little threat of a price "break." Four underwriting firms--two among the top ten in volume and two among the top seventy--reported by letter on the frequency of price "breaks" on convertibles. One, whose policy called for price cuts in lieu of holding unsold convertibles in inventory, reported price reductions on approximately five. per cent of the dollar underwriting volume over the past five years. The other three reported no price cuts on convertibles

\section{$18^{\text {Ibid. }}$, p. 148 .}

19 Friend and others, Investment Banking and the New Issues Market, p. 20 . 
and no issues held longer than a week past the offering date. 20 Three of the firms further reported that so-called "price stabilization" was rarely necessary. One firm indicated price stabilization was required on four per cent of the dollar volume over the past five years, one indicated five to ten per cent, and the third reported none (the fourth firm did not comment on this). 21 In practical terms, a successful issue is marketed "within a few hours" by simply confirming the "indications of interest" previously secured from prospective buyers.

This marketing procedure obviously does much to reduce the risk assumed by the underwriting group. It also has important implications regarding the pricing of new convertible issues offered via straight underwriting, and why-as will be explored next--such pricing is likely to differ from that encountered in rights offerings.

\section{Additional Risk in Standby Underwriting}

In a rights offering, an investment banking group is typically involved on a standby basis, and the risk the underwriters bear in such a case is substantially greater than in regular underwriting. The basic reason is that the underwriters have contracted to take up only the portion of the

20 Letters from four underwriting firms located in New York, Chícago, and Philadelphia, July, 1968.

21 Ibid. 
new issue not subscribed by the stockholders to whom the rights are issued, and this quantity can be determined only after the expiration of the rights offering, which may be from ten days to four weeks after issuance of the rights. The underwriters must commit themselves to both a "spread" and an offering price at the beginning of this period; the offering price is the same as that quoted in the rights. The risk of an adverse change in market conditions during the ten-day to four-week period is obviously great. In contrast to the regulan underwriting procedure just described, there is no chance to receive feedback information, no opportunity to make last minute changes in the offering price to adjust to changed market conditions.

There are several ways the investment banking community can offset this additional risk. The most obvious way, and one that is universaliy practiced, is to charge a larger commission than in regular underwriting.

A second method, practiced since 1947 after an alteration in Securities and Exchange Commission guidelines, is for the underwriting group to purchase rights in the open market, exercise them, and then market the convertibles immediately. The logic behind this procedure is that stockholders who sell their rights on the open market are expressing a desire not to exercise them, making it unnecessary, insofar as that portion of the issue is concerned, to wait until the expiration date of the rights offering before the investment bankers can take 
positive action to sell the unsubscribed bonds. The fact that some of the rights are sold prior to the end of the rights offering period means that the underwriters reduce to some extent the market uncertainty associated with the passage of time. 22 During an interview with a Dallas investment banking. executive, the comment was made that the rights-purchasing procedure is probably used in about a fourth of his firm's convertible marketings.23 of two other firms, both in the top ten in terms of volume, one indicated rights purchases on five per cent of the dollàr volume of convertible standby underwritings over the past five years, and the other firm one hundred per cent.24 Policies and practices in this area are obviously varied.

Thirdly, and most significantly for present purposes, the risk of standby underwriting can be reduced by underpricing the issue. Such underpricing usually comes, however, not in the form of lower offering price per se, but in the form of more attractive terms. In the eighty-issue sample, excluding five issues that had a cash feature in the conversion privilege and three issues eliminated for other reasons,

22Pilcher, Raising Capital With Convertible Securities, pp. 107-09.

$23 \mathrm{John}$ W. Turner, Eppler, Guerin and Turner, Inc., July $9,1968$.

24Letters from four underwriting firms located in New York, Chicago, and Philadelphia, July, 1968. The two smaller firms had managed no standby underwritings. 
the average offering price for thirty-eight rights issues was $\$ 1001.95$, only slightly less than the $\$ 1004.12$ average offering price on the thirty-four straight offerings. On the rights issues, however, the average conversion price of $\$ 53.40$ was 7.97 per cent greater than the $\$ 49.46$ average market price of the common stock on the offering date; while in the case of the straight issues, the average conversion price was $\$ 47.90$, a premium of 18.21 per cent over the average stock price of $\$ 40.52$. Ceteris paribus, the rights issues were the better bargain because, assuming a future rise in stock prices, the conversion feature itself would become valuable in a shorter period of time. To the extent that the present worth of this extra future value is not added to the offering price, a compensating price gap would logically develop in secondary market trading. As will be shown later, this is exactly what happens.

It is possible, of course, for other terms, such as coupon rate, to be made more favorable on a rights issue than on a straight offering. A comparison of coupon rates was rot made in the eighty-issue sample because of the great difficulty of eliminating the effect of variations in offering dates and the changes in prevailing interest rates over time, as well as variations in default risk among companies. It was readily apparent, however, that the indirect underpricing did not come in the form of differences in such terms as the call provision or the sinking fund provision. It is 
perhaps significant to note that all of the five issues with cash payment features in the conversion privilege were rights issues; the additional leverage associated with this type of conversion privilege, which is advantageous to bondholders, may represent another manifestation of the practice of underpricing rights issues.

\section{The Investment Banking Industry}

Another key to the pricing practices followed in new convertible offerings lies in the basic structure of the investment banking industry, particularly in the high degree of concentration in the industry. 25 Some 261 firms were reported to have either managed or co-managed new stock or bond underwritings totaling nearly \$20 billion in 1967.26 Narrowed to managing underwriters alone, there were 199 firms.27 But only 20 of these firms accounted for over 81 per cent of the dollar volume; and the top ten firms accounted for 60 per cent. In the case of convertible bonds specifically, the concentration figures are similar except for a smalier total number of firms. Out of 100 firms

25 For a far more thorough treatment of this subject than can be presented here, see Friend and others, Investment Banking and the New Issues Market, especially Chapter 2 by Ervin Milier, "Background and Structure of the Industry," pp. 80-
175 .

26Investment Banker-Broker AImanac, $1968 \mathrm{ed.,} \mathrm{pp.} \mathrm{6-15.}$

27 Investment Bankers Association of America, IBA Corporate Financing Bulletin, No. X (Washington, March, $\frac{1}{968}$ ), 
reported to have managed underwritings of convertible issues totaling over $\$ 4$ billion in 1967, 20 firms handled 74 per cert of the dollar volume and the top ten firms handled 55 per cent.28 Concentration in the industry has long been a source of controversy, as indicated by the major antitrust suit brought against seventeen leading investment banking firms in the late $1940^{\prime} \mathrm{s}$; the debate seems, however, to have cooled somewhat since then.29

Ironically, the effectiveness of competitive bidding in utility and railroad issues--a technique intended to overcome a failure on the part of issuing corporations to "shop around" for the best offering price and "spread"-. is partly (but not wholly) diminished by the even higher. degree of concentration than is prevalent for other types of underwriting. There were only 39 firms involved as managers in the total competitive underwriting of slightly over $\$ 5$ billion in 1967, and the top ten firms handled 88 per cent of this total volume.30 Although convertibles are seldom involved in competitive underwritings, it is worthwhile to note the fact that competitive bidding is not a cure-all for pricing problems in the industry.

\section{Both sets of concentration percentages computed from} data in IBA Corporate Financing Bulletin, ibid., pp. $8,9$. 29Friend and others, Investment Banking and the New Issues Market, p. 138 .

${ }^{30}$ Computed from data in IBA Corporate Financing Bulletin, No. $X, p p .8,9$. 
Concentration figures alone do not, of course, reveal the full nature of the pricing practices prevalent in the industry. Ten firms can compete as vigorously with one another as ten hundred. But clearly, at least, the reverse is not true: Many firms cannot avoid competition as easily as a few. It is not the purpose of this investigation to "point the finger" at the investment banking industry or to settle the issue of possible noncompetitive pricing and commission practices. It is sufficient simply to note that there are other forces leading to underpricing of new issues (and perhaps to excessive underwriting commissions) and that the state of competition prevailing in the industry does not act in a positive manner to offset them. The atmosphere, in short, is permissive.

\section{Empirical Evidence of Primary Market Underpricing}

Conclusive empirical evidence of chronic underpricing in the primary convertible bond market was uncovered via an analysis of the eighty-issue sample described previously. Three bonds were eliminated from the sample because, although they were listed during their lives on the New York Stock Exchange, they were over-the-counter securities at the time of original. issuance and it was not possible to trace price data in an adequate manner. A few issues were originally listed on the American Stock Exchange, but there was no problem tracing these issues; hence, they were left in the 
sample. The resulting list of seventy-seven issues is believed to be representative of the general population of listed convertibles marketed publicly and outstanding over the past fifteen years.

The Analytical Procedure

The analysis was conducted as follows: Various pieces of information, including coupon rate, maturity period, industrial category, conversion price, Moody's rating, offering date, and ex-rights date in the case of rights offerings, were recorded for each issue. Several types of price information were recorded: (1) On rights issues, the mid-point of the price range of the rights on the first day they traded on the exchange; (2) the offering price of the convertible; (3) the closing market price of the common stock on the offering date; (4) the first bond price recorded in secondary trading and the matching common stock price, followed by comparable sets of prices a week later, a month later, and two months later. All price data were taken from back issues of The Wall Street Journal. 31 Bonds were sometimes quoted on a "when-issued" basis in initial secondary trading, in which case the first "when-issued" trade was taken as the initial secondary market transaction. In other cases, because of a time gap between the offering date and the date the new to 1968 .

${ }^{31}$ North Texas State University microfilm files, 1952 
convertible joined the stock as a listea security on the exchange, over-the-counter transactions (traceables in this case) marked the beginning of secondary trading. Also recorded was the number of days from the offering date in straight issues, or from the first day rights were traded on the open market in rights offerings (rarely more than a day after the offering date), to the date of initial secondary trading in the bond.

These data made possible the measurement of the price gap to which the convertible moved in initial secondary trading, thus providing an indication of the extent to which the offering price was lower than would have prevailed in a perfect primary market. The bond prices a week, a month, and two months, respectively, after the initial secondary transaction provided an indication of whether the immediate gap was a "fuke" or was maintained beyond the initial flurry of trading activity in the secondary market. The dollar trading volume of the bonds at each price point was recorded in order to trace the pattern of such trading activity.

It was necessary to draw a sharp distinction between two concepts. One is the magnitude of the underpricing for overpricing) in the primary market, that is, the spread between the actual offering price in the primary market and what the offering price would have been had the primary market operated as efficiently and as perfectly as the secondary market. The other is the profit a speculator could earn by 
buying in the primary market and selling th the secondary market. The two concepts differ because stock prices do not remain stable after the offering date. Instead, they typically fluctuate either up or down, causing changes in the bond price unrelated to any underpricing or overpricing in the primary market. If the stock price rises, it would obviously be incorrect to regard the corresponding rise in the price of the bond as a measure of underpricing in the primary market. Similarly, if the stock price falls, the corresponding decline in the price of the bond on the secondary market should not be taken as a measure of overpricing in the primary market, or netted against aggregate urderpricing. On the other hand, if one merely wants to measure the profit a speculator could have attained by bridging the gap between the primary and secondary markets, the changes-whether favorable or unfavorable--in stock prices should be included as a real-life variable with which the speculator must contend. This distinction was the motivation for recording stock prices at time points matching the recorded bond prices.

Separating the two measurements was, however, still not a simple task because of two complications. First, if the stock price declines to such an extent that the bond price reaches intrinsic value and fails to decline beyond that point in response to further declines in the stock price, then the use of the full change in stock price, together with 
conversion terms, as a basis for adjusting the observed change in bond price would overstate any underpricing or understate any overpricing. The amount of such overstatements or understatements was, however, subject to estimation by computing the intrinsic value of the bonds based on Moody's index of prevailing interest rates at the various issue dates and for the various risk categories corresponding to the Moody's ratings. 32

The second complication arose from a phenomenon described in detail in Chapter $V$. There is, in general, some ratio of conversion value to intrinsic value (between 90 and 99 per cent) at which the speculative premium on a convertible is usually at its maximum. On either side of this point--that is, as the stock price, and hence the conversion value, either rises or declines--the premium tends to shrink. Since the basic objective of the underpricing measurement is to isolate the magnitude of the underpricing, other variables remaining constant, and since a correction based simply on stock price changes translated to changes in conversion value fails to hold the premiumshrinkage variable constant, a further adjustment was required. The guidelines established in Chapter V (pages 207-211) were used for this purpose.

32Noody's Industrial Manual, June, 1967, "Special Features Section," pp. a16, a18, a19; and Moody's Bond Survey, Vol. LX, various weekly issues in 1968. Yields down through Baa rating were supplied. Yields for lower ratings were computed by a procedure described in Chapter $\mathrm{V}$. 
The frequency of occurrence of these two complicating factors increased as the price points moved further out in time from the offering date. Very little adjustment was required in the initial prices recorded in the secondary. market, somewhat more was required for the week-later prices, and still more for the month-later and two-month-later prices. For this reason, and because it was impossible to make perfect adjustments, greater weight was assigned to the earlier figures in computing overall averages of underpricing per bond. 33

Results of the Analysism Underpricing

The results of the analysis were quite illuminating. First of all, as might be expected, it was found that the dollar trading volume in the secondary market was high on the first transactions and on the week-later transactions, but receded thereafter, as show in Table XV. This reflects an initial surge of trading volume, followed by more normal volume as time passed. (Although there were seventy-seven issues in the sample, volume information was not avajlable on thirteen issues in which initial secondary transactions took place in the over-the-counter market; hence, Table XV includes only sixty-four issues.)

33 The decision to use this variable weighting was made only after observing that the gaps reflected in the initial secondary market transactions were sustained through time, thus eliminating the concern that variable weighting would cause distortion in the averages. 


\section{TABLE XV}

TOTAL SECONDARY TRADING VOLUME ON

SIXTY-FOUR CONVERTIBLTS AT

SELECTED IIME POINTS

(Millions of Dollars)

\begin{tabular}{ll} 
Time Point & \multicolumn{1}{c}{ Total Volume } \\
Initial secondary trade . . $\$ 14.97$ \\
Week later . . . . . . 13.42 \\
Month later . . . . . . 6.28 \\
Two months later . . . . . 4.11
\end{tabular}

Table XVI shows the severty-seven issues arrayed in terms of the number of days elapsing from the offering date (or the first day rights were quoted on the exchange) to the first recorded secondary transaction. Over a third of the issues went into secondary trading almost immediately-within one day and often on the same day. Over half of the issues traded within fourteen days. And over eighty per cent traded within a month. The median interval was thirteen days. These brief time intervals add great leverage to the computation of time-adjusted annual rates of return available to speculators.

The average number of days to the first secondary transaction differed importantly, however, between rights offerings and straight offerings, as shown in the last two lines of Table XVI. The 43 rights offerings went into secondary trading in an average of 7.44 days, while the 34 straight offerings required an average of 27.50 days. 
TABLE XVI

NUMBER OF DAYS FRON OFFERING DATE* TO FIRST SECONDARY MIARKET TRANSACTION, SEVENTY-SEVEN CONVERTIBLES

\begin{tabular}{l|c|c}
\hline No. of Days & No. of Issues & Accumulated $\%$ \\
\hline Same day to 1 day & 27 & $35.1 \%$ \\
2 to 7 days & 9 & 46.8 \\
8 to 14 days & 4 & 51.9 \\
15 to 21 days & 8 & 62.3 \\
22 to 28 days & 14 & 80.5 \\
29 to 35 days & 8 & 90.9 \\
36 to 42 days & 1 & 92.2 \\
43 days or more & 6 & 100.0 \\
\hline
\end{tabular}

Median No. of Days, 13.

Mean Average for 43 Rights Offerings, 7.44 Days. Mean Average for 34 Straight Offerings, 27.50 . Days

*From the first day rights were quoted in the case of rights of ferings.

There was also an obvious difference between the average, unadjusted bond prices at each of the four time points in the rights offerings, and the comparable prices in the straight offerings. In the rights issues, these average prices were $\$ 1131.20, \$ 1125.00, \$ 1144.10$, and $\$ 1153.30$ at the four time points. For the straight issues, the figures were $\$ 1048.80$, $\$ 1061.80, \$ 1064.50$, and $\$ 1070.40$.

After making the adjustments described previously, Table XVII was prepared to show the magnitude of the net underpricing in the primary market. The figures represent underpricing per \$1000-denomination bond. Kights offerings are shown separately from straight offerings. The variable 
weighting referred to earlier was used to condense the underpricing figures for the four time points down to a single overall average.

\section{TABLE XVII}

$$
\begin{aligned}
& \text { SUMMARY OF UNDERPRICING MEASURES BASED ON } \\
& \text { FORTY-THREE RIGHTS OFFERINGS AND } \\
& \text { THIRT-FOUR STRAIGHT OFFERINGS } \\
& \text { (Underpricing Per \$1OOO-Denomination; } \\
& \text { Weighted Averages of Four Time Points) }
\end{aligned}
$$

\begin{tabular}{|c|c|c|c|c|}
\hline \multirow{2}{*}{ Category } & \multicolumn{2}{|c|}{ Rights Offerings } & \multicolumn{2}{|c|}{ Straight offerings } \\
\hline & $\begin{array}{l}\text { No. of } \\
\text { Issues }\end{array}$ & $\begin{array}{l}\text { Under- } \\
\text { pricing }\end{array}$ & $\begin{array}{l}\text { No. of } \\
\text { Issues }\end{array}$ & $\begin{array}{l}\text { Under- } \\
\text { pricing }\end{array}$ \\
\hline All issues & 43 & $\$ 139.19$ & 34 & $\$ 42.38$ \\
\hline $\begin{array}{l}\text { By industry category: } \\
\text { Industrials } \\
\text { Public utilities } \\
\text { Transportation } \\
\text { Banking and fin. }\end{array}$ & $\begin{array}{r}31 \\
2 \\
3 \\
2\end{array}$ & $\begin{array}{r}\$ 127.94 \\
70.43 \\
182.63 \\
138.09\end{array}$ & $\begin{array}{r}31 \\
1 \\
1 \\
1\end{array}$ & $\begin{array}{l}\$ 30.54 \\
28.58 \\
55.87 \\
37.25\end{array}$ \\
\hline $\begin{array}{l}\text { Issues with cash con- } \\
\text { version features }\end{array}$ & 5 & $\$ 173.96$ & & \\
\hline $\begin{array}{l}\text { By Moody's ratings: } \\
\mathrm{Aa} \\
\mathrm{A} \\
\mathrm{Baa} \\
\mathrm{Ba} \\
\mathrm{B} \\
\text { Not rated }\end{array}$ & $\begin{array}{r}1 \\
1 \\
13 \\
19 \\
2 \\
2\end{array}$ & $\begin{array}{r}\$ 268.69 \\
82.57 \\
104.09 \\
125.86 \\
256.70 \\
138.09\end{array}$ & $\begin{array}{r}2 \\
9 \\
18 \\
4 \\
1\end{array}$ & $\begin{array}{l}\$ 25.04 \\
37.42 \\
51.70 \\
21.51 \\
37.25\end{array}$ \\
\hline
\end{tabular}

*Excludes issues with cash conversion features.

The weights were $.4, .3, .2$, and .1 , respectively, for the four time points as they move out in time. For example, in the case of all rights offerings, the indicated underpricing 
was $\$ 129.22$ at the first time point, $\$ 139.73$ at the second time point, $\$ 149.40$ at the third point, and $\$ 157.03$ at the fourth point (indicating that the price gap was sustained and even increased somewhat over time); applying the weights to this series results in the overall average of $\$ 139.19$ shown in Table XVII. Similarly, the four unweighted figures for the straight issues were $\$ 38.18, \$ 36.83, \$ 52.48$, and $\$ 55.60$, the weighted average being the $\$ 42.38$ show in the table. These price gaps indicate that original average offering prices could have been increased by 13.9 per cent for the rights issues and 4.2 per cent for the straight issues, had imperfections not existed in the primary market.

To the extent that these percentages can be generalized to apply to the total volume of convertible underwriting from, say, 1950 through 1967, the total underpricing in the primary market for publicly offered convertibles would approximate $\$ 1.3$ billion.

Comparing the two sets of vertical columns, one is immediately struck by the large difference between underpricing of rights issues and underpricing of straight issues. This observation is fully consistent with the fact, discussed previously, that standby underwriting is inherently riskier from the investment banker's viewpoint than straight underwriting.

While there are obvious differences in the underpricing figures among the various industry categories, the number of 
issues in the public utility, transportation, and banking and finance categories is so small as to prohibit drawing any conclusions on this basis.

Issues whose conversion features involved an additional cash payment were tabulated separately. The fact that the premium of $\$ 173.96$ is larger than the $\$ 139.19$ average for all rights issues tends to support the belief that the secondary market will eliminate, as far as secondary buyers are concerned, the leverage advantage such issues possess. The secondary market is an efficient "leveler," a characteristic not so prevalent in the primary market.

It is also quite interesting to note, in the grouping by Moody's ratings, that if allowance is made for the small number of issues in some categories, there is a noticeable pattern of increasing premiums corresponding to diminishing quality. That is to say, the secondary market is evidently less risk-conscious than the underwriting managers and corporate managers whose interaction sets of fering prices in the primary market. It may be appropriate at this point, also, to recall the comments made in Chapter II regarding default risk. It was noted there that convertibles have not, contrary to commonly published opinion, had a worse default record than nonconvertibles and probably do not merit the automatically lower agency ratings given them. This discovery may already have been made by secondary market purchasers. 


\section{Speculative Profits}

Falling back on the unadjusted price data, what opportunity was there for earning speculative profits by bridging the gap between the primary and secondary markets? Table XVIII provides the answer, expressed in terms of both raw percentage returns and time-adjusted annual yields (the latter being computed on a noncompounded basis).

Again, a distinction must be drawn between straight offerings and rights issues. Whether speculative operations would be possible in the case of straight offerings would hinge upon the access of the speculator to the primary convertible market. The very existence of yields of the magnitude shown in the table suggests that such access is restricted. In computing the rates of return resulting from margin purchases, it was assumed that interest at the rate of six per cent annually was paid on the amount borrowed. In both margined and nonmargined purchases, the standard commission rate on bonds was deducted from the sale proceeds. before calculating the yields. Taxes, however, were disregarded.

In the case of rights offerings, access to the primary market, generally speaking, could occur only if the speculator were a stockholder at the time the rights were issued, except for the bonds marketed by the standby underwriter. There is, however, an access route that occupies an intermediate position between the primary and the secondary markets, namely, the 
TABLE XVIII

RAW AND ANNUAL RATES OF RETURN RESULTING

FROM. PURCHASE OF CONVERTIBIES AT

OFFERING PRICE AND SUBSEQUENT

SALE IN SECONDARY MARKET

\begin{tabular}{|c|c|c|c|c|}
\hline \multirow[b]{2}{*}{ Category } & \multicolumn{4}{|c|}{ Time Point of Sale } \\
\hline & $\begin{array}{l}\text { Initial } \\
\text { Transac- } \\
\quad \text { tion }\end{array}$ & $\begin{array}{l}\text { Week } \\
\text { Later }\end{array}$ & $\begin{array}{l}\text { Nonth } \\
\text { Later }\end{array}$ & $\begin{array}{l}\text { Two } \\
\text { Months } \\
\text { Later }\end{array}$ \\
\hline $\begin{array}{l}\text { Straight offerings } \\
\text { Average holding per- } \\
\text { iod in days }\end{array}$ & 27.50 & 34.65 & 57.18 & 87.76 \\
\hline $\begin{array}{l}\text { Nonmargined purchase } \\
\text { Raw yield } \\
\text { Annual yield }\end{array}$ & $\begin{array}{c}4.2 \% \\
55.7\end{array}$ & $\begin{array}{c}5.5 \% \\
57.9\end{array}$ & $\begin{array}{l}5.8 \% \\
36.8\end{array}$ & $\begin{array}{r}6.2 \% \\
25.5\end{array}$ \\
\hline $\begin{array}{l}\text { Purchase on } 60 \% \text { mar- } \\
\text { gin } \\
\text { Raw yield } \\
\text { Annual yield }\end{array}$ & $\begin{array}{c}6.7 \% \\
88.9\end{array}$ & $\begin{array}{l}8.8 \% \\
92.4\end{array}$ & $\begin{array}{l}9.0 \% \\
57.3\end{array}$ & $\begin{array}{r}9.6 \% \\
40.0\end{array}$ \\
\hline $\begin{array}{l}\text { Purchase on } 20 \% \text { mar- } \\
\text { gin } \\
\text { Raw yield } \\
\text { Annual yield }\end{array}$ & $\begin{array}{r}19.2 \% \\
254.8\end{array}$ & $\begin{array}{r}25.2 \% \\
265.5\end{array}$ & $\begin{array}{l}25.1 \% \\
160.0\end{array}$ & $\begin{array}{l}26.0 \% \\
108.1\end{array}$ \\
\hline $\begin{array}{l}\text { Rights offerings } \\
\text { Average holding per- } \\
\text { iod in days }\end{array}$ & 7.44 & 13.93 & 36.86 & $\begin{array}{c}66.86 \\
.\end{array}$ \\
\hline $\begin{array}{c}\text { Nonmargined purchase } \\
\text { Raw yield } \\
\text { Annual yield }\end{array}$ & $\begin{array}{c}11.9 \% \\
584.2\end{array}$ & $\begin{array}{l}10.0 \% \\
314.3\end{array}$ & $\begin{array}{r}13.1 \% \\
129.6\end{array}$ & $\begin{array}{l}12.3 \% \\
67.0\end{array}$ \\
\hline $\begin{array}{l}\text { Purchase on } 60 \% \text { mar- } \\
\text { gin } \\
\text { Raw yield } \\
\text { Annual yield }\end{array}$ & $\begin{array}{c}19.8 \% \\
969.7\end{array}$ & $\begin{array}{r}16.4 \% \\
430.8\end{array}$ & $\begin{array}{r}21.4 \% \\
212.0\end{array}$ & $\begin{array}{l}22.6 \% \\
123 \cdot 4\end{array}$ \\
\hline $\begin{array}{l}\text { Purchase on } 20 \% \text { mar- } \\
\text { gin } \\
\text { Raw yield } \\
\text { Annual yield }\end{array}$ & $\begin{array}{r}59.0 \% \\
2896.9\end{array}$ & $\begin{array}{r}48.9 \% \\
1280.5\end{array}$ & $\begin{array}{r}63.0 \% \\
623.9\end{array}$ & $\begin{array}{r}65.6 \% \\
358.1\end{array}$ \\
\hline
\end{tabular}


purchase of rights on the open market as soon as they are offered for sale there. This was the method by which the yields in Table XVIII were computed. Specificaliy, it was assumed that the rights were purchased on the first day prices were quoted on the right on the exchange, taking the mid-point of the high and low for the day as the unit purchasing price of the rights. An allowance was made for the cost of rights sufficient to buy one bond and the brokerage commission required for acquisition of the rights. It was further assumed that the rights were exercised, the bond purchased at the offering price, then sold at the time points indicated. On the margined purchases, it was assumed that. a six per cent interest rate applied to borrowed funds, and. that the rights purchase was margined along with the bond. It seems unusual, in view of the yield figures on the rights issues, that the stockholders who sold their rights on the first day they were quoted were willing to sell out so cheaply. The rights would, more logically, be sold at a price high enough to recover the present value of the future benefits associated with the conversion feature of the bond and with expected stock and bond price behavior. There is probably a twofold explanation for this pricing peculiarity. First, the stockholders who dump their rights on the market on the first day will tend to be the least optimistic of the company's owners. Secondly, they may tend to be smaller, less sophisticated investors who cannot afford to exercise the 
rights and who are, at the same time, not capable of properly assessing the fair market price of the rights. Not only are there no previous rights quotations to guide them, but they will be influenced by the offering price of the bond rather than by the higher bond prices that appear in subsequent secondary trading. The low initial rights quotations are a carryover of the imperfection prevailing in the primary market. This carryover enables a speculator, moving swiftly, to reap large profits.

As for the optimal holding period, the answer is readily provided by the annual yields in Table XVIII. On the straight issues, the purchase positions should, idealiy, have been liquidated within a week following the first recorded secondary market transactions, or shortly thereafter; this would have meant a total holding period of four to five weeks. On the rights issues, the positions should have been liquidated on the first secondary transaction, involving a total holding period averaging only a week. Even with long-term tax rates considered, there is no advantage to be gained by holding the bonds any longer.

Whether the annual yields could have been realized in practice would have depended upon the speculator's ability to keep his funds fully employed at all times. The full yields shown would have been impossible to obtain relying. solely on the issues in the sample. But something approximating the full yield may have been possible by conducting this type 
of speculative operation throughout the general population of convertibles.

\section{Some Clarifying Remarks}

In thinking about underpricing in the primary convertible market, it is important to maintain a distinction between the price gaps caused by such underpricing and speculative premiums, the latter having been defined in Chapter I as the excess of market price of a convertible over the higher of either conversion value or intrinsic value. It might seem, at first blush, that the recent declines in speculative premiums in the secondary market-mcaused by a combination of tight money and the new Federal Reserve margin requirement on convertibles--would snvalidate an underpricing measurement applied to bonds outstanding over a fifteen year period.

To the extent that underpricing is a supply phenomenon, however, a decline in the general level of speculative premiums has no direct influence on the magnitude of the price gaps taken as a measure of underpricing. For example, suppose an existing bond is convertible into ten shares of stock, that the current market price of the stock is $\$ 100$ so that the current conversion value of the bond is $\$ 1000$, and that the intrinsic value is irrelevant (that is, less than the conversion value, say $\$ 900)$. Assume, hypothetically, that this bond sells for $\$ 1200$ on the secondary market prior 
to the imposition of the Federal Reserve margin requirement, that is, at a 20 per cent speculative premium. A new convertible marketed at this time and carrying the same conversion terms, with current stock price also at $\$ 100$, would be sold in the primary market at an offering price of perhaps $\$ 1100$. The new bond would go immediately to $\$ 1200$ on the secondary market because of the nine-plus per cent price gap. Viewing the same two situations immediately after imposition of the new margin requirement, the existing bond would sell for perhaps $\$ 1100$, reflecting a ten per cent drop in the speculative premium due to a drop in demand on the part of margin speculators. The new issue, however, would be sold on the primary market for $\$ 1000$ rather than $\$ 1100$ as in the original case. The new issue would immediately go to $\$ 1100$ in secondary trading, with no decline whatever in the price gap compared with the first case.

To verify the validity of this reasoning, an effort was made to examine the price gaps on all New York Stock Exchange convertibles issued since imposition of the Federal Reserve margin requirement on March 11, 1968. The issues were isolated by comparing Wall Street Journal listings at midAugust with those in early March, 1968. This comparison produced a list of all listed convertibles issued during the intervening period except any that happened not to have traded on the mid-August, 1968, date. There were twelve issues, a list of which is shown in the appendix. Offering prices and 
offering dates were obtained from supplements to the Moody's Manuals. Then, as in the main analysis described earlier, the first recorded secondary market price was determined, along with the number of days from the offering date to that first secondary transaction. In this case, no attempt was made to determine week-later, month-later, or two-monthlater prices, nor to adjust for any stock price changes. The average offering price was $\$ 1000$ for the twelve issues. Oddiy enough, all were straight issues; no rights issues were involved. Ths first secondary price on one of the twelve issues was $\$ 977.50$ and another was $\$ 1000.00$. But all others were in excess of the offering price, ranging as high as $\$ 1162.25$. The average price at the first secondary transaction was $\$ 1054.70$. This price gap of $\$ 54.70$ agrees very closely with the $\$ 42.38$ reported in Table XVII for straight issues. Furthermore, the average holding period of 20.0 days agrees closely with the 27.5 days reported in Table XVI.

This tendency for the price gaps to persist through changes on the demand side of the market fully justifies use of the word "chronic" in describing the imperfection prevailing in the primary convertible bond market.

An Explanatory Theory

Fitting all of the pieces together, it should now be possible to outline a theory to explain underpricing in the 
primary convertible market. There are several major forces that act to encourage underpricing. There is, first of all, a collection of defects or imperfections in the marketing and pricing system.

\section{Imperfections in the Marketing and Pricing System}

One form of built-in imperfection in the primary market stems from the fact that investment bankers and issuing corporations face a downsloping demand curve for new convertible issues, as hypothetically illustrated in Figure 2 .

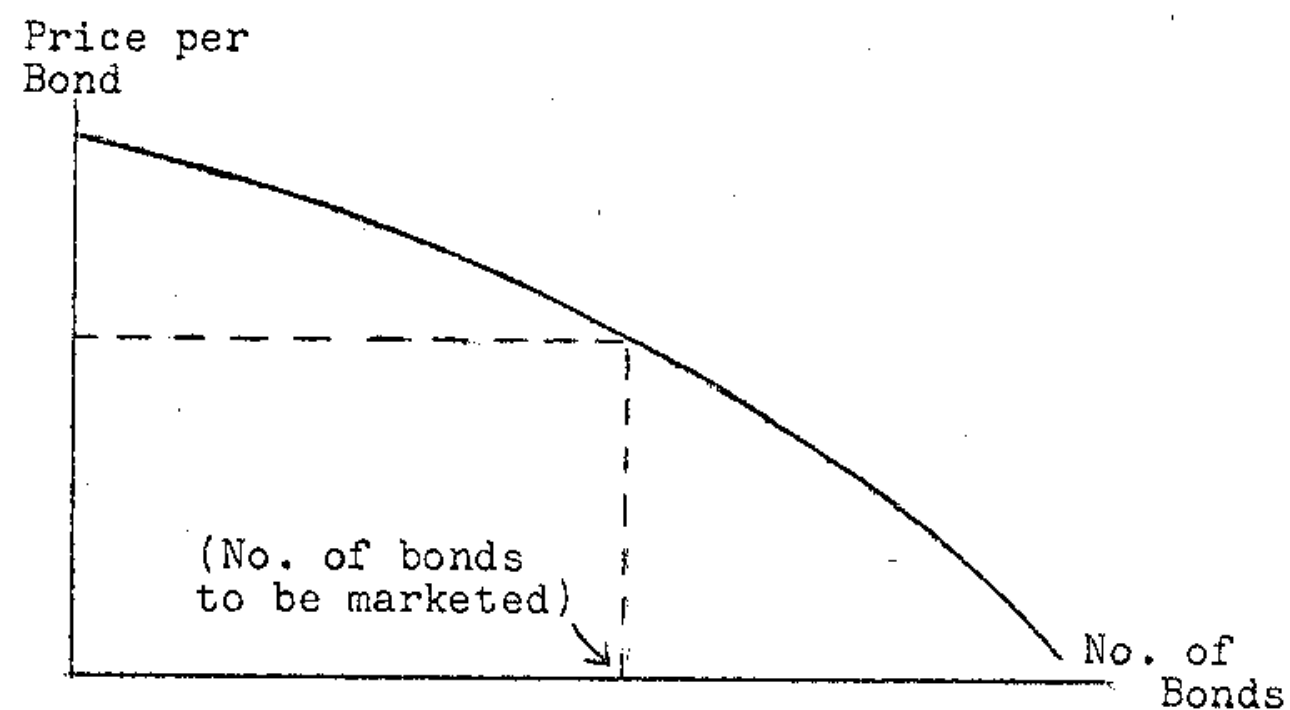

Fig. 2--Hypothetical demand curve for new convertible bond.

The managing underwriter, in cooperation with the management of the issuing company, attempts to set a single price that will succeed in disposing of the entire issue being marketed ("price" being taken here as representative of both the offering price of the bond and the nature of its conversion 
feature and other indenture terms). The investment banker does not, at least as a matter of initial intention, follow an incremental pricing policy in which the market is segmented and a different price applied to each segment so as to maximize revenue. While there are occasionally some price "breaks" in the marketing process, these are mich in the minority and are not, in any case, a deliberate attempt at incremental pricing.

With a single-price policy, the offering price, conceptually speaking, would be determined by following the dashed vertical line up to the demand curve, then reading the price on the vertical scale. As indicated by the area lying between the demand curve and the dashed horizontal. line, there are some buyers who subjectively value the bond at more than the price set by the underwriter and who would willingly pay a higher price than the initial offering price. The initial offering price is, in short, a marginal price that does not denote average value in the minds of actual buyers.

The general concept of marginal pricing is well known in the secondary securities markets. For example, John Burr Williams said in 1938: "Thus marginal opinion will determine market price. . The bid and asked quotations will reflect the opinions of the most optimistic non-owner and the least optimistic owner. . At this margin, opinion, mere opinion, 
will determine actual price. . "34 A security could fall to, say, $\$ 5$ on the secondary market but be worth $\$ 100$ in the mind of the average owner (more than $\$ 100$ for some investors, less for others, continuing down to $\$ 5)$. The average owner will obviously not sell out at $\$ 5$; he will simply hold his shares. The same basic concept, with modifications on the supply side, has validity in the primary convertible bond market. It can be further theorized that some convertible bond purchasers who lie, figuratively, to the left of the vertical dashed line in the graph are not able to purchase as large a quantity of bonds as they desire. This almost surely happens in practice because of the nature of the marketing process in the primary market. There is no central meeting place as in the secondary market. And there is an intense element of exclusivity in the formation of underwriting and selling groups. Researchers in the Merrill Lynch underwriting department state, for example, that

One of the most trying tasks of company officials. . is to handle direct requests from underwriting firms asking for participation in the syndicate, often on the basis of some business or personal connection with the company or its officers or directors; the best policy is to refer all requests of this kind to the managing underwriter for appropriate disposition. 35

Such underwriters would obviously not be trying to gain

34John Burr Williams, The Theory of Investment Value (Amsterdam, 1938), p. 12 .

35Leness, Martin, and Gilmartin, New Money for Business, Techniques of Long-term Corporate Financing, p. 65. 
entrance to the syndicate via the "back door" if the direct route were not barred. An investment banker, in an interview, mentioned the following factors as decisive in the formation of underwriting groups: (1) personal and business friendships and rivalries; (2) historical alignments and groupings of firms, plus the tendency for issuing corporations, via an underwriting manager, to become associated with a limited group of underwriters on a continuing basis; (3) past experience with the selling efficiency of underwriting and dealer firms; (4) prestige and ranking of underwriters in the industry, a matter of such importance to investment bankers that some will refuse to participate in an underwriting if, for example, the firm's name is not positioned in a relatively high place in "tombstone" advertisements; (5) the constant presence of newer and less prestigous underwriting and seliing firms trying to gain participation in underwritings; and (6) such factors as the size and risk of the new issue. 36

It is important that no hasty judgments be formed regarding exclusivity in the formation of underwriting groups. Institutions evolve in a society in response to environmental forces: There is undoubtedly some "method in the madness" and if the system is imperfect, the next best workable arrangement might be even more so. It should also be noted

$$
36 \text { John } w \text {. Turner, Eppler, Guerin and Turner, Inc., }
$$
Dallas, Texas, July 9, 1968. 
that less exclusivity exists in the formation of the retail selling group than in the formation of the risk-bearing underwriting group, even though the two groups typically overlap. In the final analysis, however, it must be concluded that the process by which syndicates in general are formed is not one that tends to insure that every interested buyer is reached or that every buyer who is reached is able to purchase 211 the shares he wants at the offering price. Tendencies in this direction are reinforced by the awkwardness of any attempt to reallocate allotments of a new issue made to the various members of the underwriting and selling group. It is very uncommon for the risk-bearers to shift their relative commitments in the issue; once an underwriter agrees, informally or otherwise, to take a position of fered to him by the managing underwriter, his continuing reputation and prestige--indeed, the very existence of his firm in the industry--hinges upon his fulfilling the commitment he has made. There is a procedure that permits some reallocation among the nonmrisk-bearing retailers, but it is an inherently inefficient procedure and is not often used. Instead, retailers who fail to market the allotment made to them simply tend not to be invited to participate in future issues. 37

The significance of these observations is that the marketing system in the primary convertible bond market tends 
to leave unsatisfied demand on the left end of the demand curve. The effective demand curve, so to speak, is Iower than the potential demand curve. The marketing operation bypasses individuals who value the convertible at a relatively high dollar amount, or restricts the number of bonds such individuals can buy, forcing the underwriting and selling group to seek out a marginal buyer corresponding to a lower offering price. The efficiencies inherent in a centralized trading place, such as the secondary market for Iisted securities, are missing in the primary market. When the new convertible goes into secondary trading, the unsatisfied individuals who value the bond at a relatively high amount will bid for additional bonds at a price higher than the offering price. To the buyers located originally "at the margin," or near it, such bids represent windfall gains, profits over and above the subjective value they place on the security. The original buyers on the right end of the demand curve should, in theory, continue to sell out to those on the left end until all individuals to the left of the point marked by the last secondary trading price are satisfied; equilibrium, at least of a temporary nature, will then exist.

This explanation helps account not only for the flurry of high trading volume found in the empirical data, but also for the tendency of the price gaps between original offering 
time. This latter discovery also weakens the possibility that much of the price gap is created by speculators who are attracted to secondary trading but were never really a part of the original potential demand curve. Another pricing consideration is that the issuing corporations, being the clients of the investment banking community, are in an apparently natural position to press for higher offering prices (and lower commissions). But for the larger corporations, which account for the bulk of the new-issue volume, limitations on the amount of pressure that can be brought to bear are imposed by the high degree of concentration in the investment banking industry. There are, in short, large underwriters to match large issuers.' The opportunity for "shopping around" in such a situation is limited. The smaller issuers face "shopping" restrictions, too, including the higher risk involved in their securities, and geographical or other limitations on the number of investment bankers they can feasibly contact. One need only observe the fact that competitive bidding is an almost norexistent practice except where it is required by governmental mandate, to be convinced of the "shopping" limitations faced by issuing corporations in general. When competitive bidding is required, "The result. . . is usually a higher price to the company and a higher price to the public than in a negotiated transaction involving the same security." 38 or, to turn 
the statement around, noncompetitive underwriting usually results in a lower offering price to the public and lower proceeds for the corporation. This is not to suggest that universally required competitive bidding is desirable or workable. It does indicate, however, that some underpricing of new issues is encouraged by the almost complete lack of competitive bidding outside of the regulated industries, and by the general restrictions on the ability of the issuing corporations to "shop" in negotiated underwritings.

It is also possible that corporate financial managers are less motivated to press for a higher offering price on a new convertible than on other types of securities. As an alternative to the sale of a straight debt issue, a convertible makes possible a lower coupon rate and other terms more favorable to the company. As an alternative to the sale of a new stock issue, the convertible often brings in higher proceeds (see pages 56, 57). Thus, the corporate manager may feel he is "getting a good deal," reducing his incentive. to press for higher proceeds by closer bargaining with the investment bankers.

\section{The Influence of Institutions}

The influence of institutional investors in the security markets is a cloudy subject, as indicated by the present desire of the Securities and Exchange Commission to make a complete investigation. The effect of institutions on the 
pricing of new securities may well be mixed. In the first place, there is little doubt that the presence of large institutional buyers in the primary market can create pressure on the investment banking community to reduce offering prices or to improve the terms of the issue. 39 Big buyers in any industry can exert some influence in the direction of discount prices. Discount prices may, however, be fully justifiable on the grounds of lower selling cost. Furthermore, it does not necessarily hold that institutional demand operates only in the direction of lower offering prices. Not only are institutions under constant pressure to keep funds productively invested, one theory states that institutions have a flatter utility curve over time, that is, have less of an aversion to long-term investments. The discount rate they apply, implicitly or explicitly, to future income streams is correspondingly lower than for individuals, and estimates of present value consequently higher.40 There may be some tendency, therefore, for institutions to cause higher offering prices than would occur in their absence.

It is conceivable that institutions mainly increase one's awareness of the defects already present in the primary

39 In this connection, see comments by Leness, Martin, and Gilmartin, ibid., pp. 14, 117; and Pilcher, Raising Capital With Convertible Securities, p. 119.

40 See Daniel Seligman and T. A. Wise, "New Forces in the Stock Market," Fortune, LXIX (Feb., 1964), 92-95, 194-206. 
marketing system and intensify the effect of such imperfections. If there is a tendency for the primary marketing operation to leave unsatisfied buyers, then the funneling of increasing quantities of new issues into institutional hands either through direct placement or through close working relationships with investment bankers in public offerings, may mean a larger number of unsatisfied individual investors. As one writer puts it, "The development of the private placement mechanism . . raised the possibility that a significant portion of the highest-quality corporate bonds might be siphoned away from the general public markets." 41 It should be remembered, however, that aggregate individual demand has been declining over the years and is being replaced by institutional demand, so that the potential for "unsatisfied demand" among individuals is also shrinking.

A further exploration of the influence of institutional buyers on offering prices and on secondary trading prices is beyond the limits of this project. Until further research is conducted, nothing really conclusive can be said about the influence of institutional investors on new-issue prices.

The Problem of Risk

Perhaps the most important key to a theory of primary market underpricing is the problem of risk faced by the

41 Friend and others, Investment Banking and the New Issues Market, p. 340 . 
investment banking fraternity in the marketing of new issues. This risk, it was observed, is particularly acute in the case of standby underwriting in rights offerings. While some of the risk is eliminated by methods other than underpricing, the remaining risk is probably greater than can be compensated for by average commission charges. One estimate of overall average "spreads" for straight public offerings (excluding out-of-pocket expenses paid by the corporation) is 1.00 to 1.75 per cent of gross proceeds for convertibles --compared with 0.75 to 1.50 per cent for straight bonds, 2.25 to 3.00 per cent for straight preferred stocks, and 4.00 to 8.00 per cent for common stocks.42 In the case of convertibles, as well as other bonds, there is obviously little room in these figures for pricing error. While commissions rise significantly in standby underwritings, the risk rises more than proportionately. Underpricing the new issue is an almost inevitable escape valve.

The risk borne by the investment banker is, moreover, aggravated by one-sided pricing flexibility. If the issue is priced too high, a downward price "break" may be necessary to market all of the issue--with the underwriters, not the corporation, bearing the full loss. If, on the other hand, the issue is underpriced, the underwriters lose only a negligible commission, with the opportunity loss caused by 
the underpricing falling on the issuing corporation. Once an offering price is printed in the prospectus, there is no way to raise it. Even the Securities and Exchange Commission mies regarding so-called "price stabilization" efforts by underwriters specifically prohibit actions that will raise the market price of the security (or the price of the matching common stock in the case of a convertible), restricting stabilization efforts to prevention of a price decline. 43

In such a "heads you win, tails we lose" situation, underwriters cannot be condemned for underpricing new issues. They can, perhaps, be criticized for failing to develop a more efficient marketing system that will reach a broader base of new security buyers.

\section{Summary and Conclusions}

The findings presented in this chapter can be summarized by saying, first of all, that conclusive empirical evidence of underpricing in the primary convertible bond market was found. The overall average underpricing was $\$ 139.19$ per $\$ 1000$-denomination bond in the case of rights offerings, and $\$ 42.38$ in the case of straight public offerings. To the extent that it is safe to generalize from the sample of listed convertibles examined in the study to the general population

${ }^{4} 3$ Securities and Exchange Commission, Compilation of Releases Dealing With Matters Arising Under the Securities Act of $\frac{1934}{1968), ~ a n d ~} \frac{\text { Investment Advisers Act of }}{\text { Release No. } 3505 \text {. }}$ (Washington, 
of publicly-marketed convertibles, the total underpricing over the past seventeen years exceeds $\$ 1.3$ billion. It was also found that underpricing was greater on issues with additional cash payments involved in the conversion privilege. In addition, the magnitude of the underpricing varied directly with declines in Moody's ratings, suggesting that secondary market buyers are less risk-conscious than the rating agencies or the underwriters.

The chronic underpricing in the primary convertible bond market can be explained on the basis of (1) A downsloping demand curve faced by investment bankers, combined with a single-price policy and a marketing system that leaves unsatisfied demand at the original offering price. (2) Restrictions on the ability of issuing corporations to "shop" among investment bankers for higher offering prices (or lower commission spreads) and, in the case of convertibles, less motivation to do so. (3) The tendency for underwriters to compensate for risk partly by underpricing the issue rather than through higher commission spreads or other means; risk --and underpricing--are particularly great on rights offerings in which the investment banker provides standby services.

A speculator bridging the gap between the primary and secondary convertible markets in the period studied could have earned rather spectacular profits. In the case of straight public offerings, the profit expressed in terms of 
an annual yield before taxes ranged from 55.7 per cent for nonmargined purchases to 254.8 per cent for purchases on 20 per cent margin, with an average holding period of four to five weeks. In the case of rights offerings, the annual yields ranged from 584.2 per cent for nonmargined purchases to 2896.9 per cent for purchases on 20 per cent margin, with an average holding period of about a week. Such profits came mainly from underpricing in the primary market but were also affected by changes in bond prices associated with changes in stock prices occurring after the offering date. Access to the primary market would have been limited in the case of the straight offerings, but the profits on the rights offerings were computed on the assumption that access was gained via purchase of rights on the first day they were offered on the secondary market. The failure of these early sellers of rights to demand the full value of the rights denotes irrational or very poorly informed behavior on their part. 


\section{CHAPTER V}

\section{THE PARTIAL HEDGE}

This and the following chapter are devoted to two special secondary-market hedging techniques. Both involve buying a convertible and simultaneously selling short the common stock into which the bond is convertible. In one technique, which might be labeled the "full hedge," the investor sells short approximately the same number of shares as that into which the bond is convertible, thus generating (in ideal cases) a full profit if the price of the stock declines and a zero return if the price of the stock rises. The full hedge is explored in the next chapter. The other technique, which is the one to be investigated in this chapter, involves--again, in ideal form--selling short one-half the number of shares into which the bond is convertible. Such a "partial hedge" will in theory produce a profit, though a more moderate one, regardless of which direction the stock moves. Graham, Dodd, and Cottle, in a one-paragraph description of the technique, call the partial hedge "probably the most scientific method of hedging, since it requires no opinion as to the future course of prices."1 p. 626 .

${ }^{1}$ Graham, Dodd, and Cottle, Security Analysis, 4th ed., 
The partial hedge is indeed amenable to scientific approach. The unanswered question is whether it is also rational and profitable, and whether it operates in a relatively perfect or relatively imperfect market environment.

The distinction drawn earlier between internal and external market comparisons cannot be neatly maintained in the case of either the full hedge or the partial hedge, since the two techniques involve commitments in both the stock market and the secondary convertible bond market. They represent, in a manner of speaking, a combination internal/external approach.

Problems in the Partial Hedge

A profit is assured in the partial hedge only if the current market price of the bond, the intrinsic value, and the conversion value are all three equal, and if the intrinsic value does not subsequently decline. For example, if the convertible selis for $\$ 1000$ on the secondary market and is convertible into ten shares of common stock currently selling for $\$ 100$ per share, the hedger would buy the bond and sell short five shares of the stock. If the stock subsequently rises to $\$ 150$ per share, the hedger would make $\$ 500$ on the bond and lose $\$ 250$ on the short sale, netting a $\$ 250$ profit. On the other hand, if the stock declines to $\$ 50$ per share, the hedger would earn $\$ 250$ on the short sale and would lose nothing 
on the bond provided the intrinsic value of the bond is $\$ 1000$, the same as the purchase price of the bond. The first major problem in the partial hedge is that such a perfect partial hedge situation rarely if ever exists.

While the intrinsic value and the conversion value may be equal, the current market price of the bond is almost always higher because of speculative premiums on the bond. Beyond some level, these speculative premiums can create an unstable situation in which the potential partial hedge profits must be nil. This is true for two reasons. First, the speculative premium typically shrinks as the conversion value rises above intrinsic value. If the partial hedger waits until the speculative premium declines at higher levels of conversion value, he subjects himself to loss through a reverse movement in conversion value. And if he buys when conversion value is near intrinsic value, he subjects himself to loss through decline in the speculative premium. The speculative premium also declines as the conversion value falls below intrinsic value. If the hedger buys the bond when conversion value is near intrinsic value, a decline in the market price of the stock will trigger a loss in speculative premium that may not be offset by profit on the short sale. And if he buys when conversion value is well below intrinsic value, a rise in the market price of the stock may generate losses on the short sale that are not offset by an increase in the speculative premium; and the risk is compounded by the 
fact that the conversion value has less chance to rise above intrinsic value, and thus less chance of producing a hopedfor rise in the market price of the bond via the conversion feature itself.

In short, the speculative premium is typically at a maximum when the conversion value is near intrinsic value; the premium declines on either side of this point--that is, with either a rise or a fall in the stock price. Since the perfect partial hedge is also to be found when conversion value is near intrinsic value, the speculative premium acts as a potential offset to what would otherwise be certain or nearly certain profits.

A second danger is that the level of speculative premiums may decline because of stimuli originating outside of the hedging situation itself. The general level of speculative premiums has declined over recent years, for example, because of a combination of tight money (making margin loans unavailable) and the new Federal Reserve margin requirement on convertibles. A reduction in the margin requirement on stocks, if it occurred, could be expected to suck speculative funds out of convertibles and into stocks, reducing speculative premiums in the process. General stock price movements can also affect the level of speculative premiums, aside from the price movement of a particular convertible-matching stock. Such external influences on the level of speculative premiums have mixed blessings, of course. A decline in speculative 
premiums while the hedger is "engaged in a hedging transaction will have an adverse effect on profits. But the market environment may be more favorable for subsequent hedges. Although speculative premiums create another variable. for the partial hedger to contend with, it would be premature to conclude that the partial hedge is inherently profitless, provided the hedger can do two things. First, he must be able to gauge when speculative premiums on a particular bond are above "normal" and are subject to excessive decline, in which case he would not engage in the partial hedge. SecondIy, he must somehow determine what the "normal" pattern of speculative premiums is, and if, indeed, such a "normal" pattern even exists. If the decline in the speculative premium triggered by a change in the price of the particular convertible-matching stock can be predicted with reasonable accuracy, partial hedge profits may be possible. As Ashby Bladen put it (though not in connection with the partial hedge as such),". . In normal markets the actual effective floor under a good-grade convert is likely to be somewhat above its straight bond value." 2 Thus, it is not the existence of speculative premiums that in itself need concern the partial hedger. His concern is with the amount of change in the speculative premium and whether the change will adhere to a predictable pattern.

${ }^{2}$ Ashby Bladen, Techniques for Investing in Convertible Bonds, Salomon Brothers and Hutzler, New York, 1966, p. 21. 
Another major problem in the partial hedge is the danger of decline in intrinsic value. A decline in the intrinsic value of $a b$ ond is a source of loss even on direct commitments in convertibles, but only when conversion value declines below intrinsic value. In direct commitments, a decline in intrinsic value can, more accurately, act as a source of additional loss--that is, in addition to the loss caused by an adverse movement in the matching stock. In direct commitments, potential shrinkage in intrinsic value is a matter more or less incidental to the investment technique itself. In the partial hedge, however, prospective declines in intrinsic value are crucial because the technique itself relies on the stability of intrinsic value to provide profits when the matching stock moves downward.

There are two possible causes of decline in the intrinsic value of a convertible. One is a rise in generally prevailing interest rates. The other is deterioration in the creditworthiness of the company. In the latter case, decline in the market price of the matching stock may go hand-in-hand with credit deterioration, thereby compounding the risk faced by the hedger. Although the findings of previous chapters cast suspicion on the validity of agency ratings, restricting partial hedge commitments to only the highest grades of convertibles available may remove some of this second type of . intrinsic value risk. That was the policy followed in the study described on following pages. 
All of the problems of the partial hedge can be expressed in terms of the final and most complex task--determining exactly how many shares of common stock the partial hedger should sell short per \$1000-denomination bond purchased. This is the key variable that will determine the size of partial hedge profits and whether such profits are positive or negative. As has been indicated, a perfect partial hedge, if it existed, would call for selling short exactly one-half the number of shares into which the bond is convertible. A rise in the stock price would then generate exactly as much profit as a decline of the same magnitude (ignoring small differences in commission charges). This attempt to equate potential profits was taken as a fundamental objective of the partial hedger; and it was assumed that the partial hedger is indifferent as to whether the stock price rises or falls. The question is, how should the number of shares sold short be varied when speculative premiums enter the picture, or when intrinsic values may change, or when the potential rise in the stock price is likely to be of greater or lesser magnitude than the potential decline?

An especially exasperating fact is that no amount of gazing at historical stock and bond price data can reveal in simple fashion how many shares the partial hedger would have sold short in any particular situation, or whether a profit would have subsequently resulted, unless one also assumes omniscient ability to predict subsequent price changes. The 
researcher can spot many profitable partial hedge situations in the historical data, and he can increase these observed profits at will be assuming a small short position in rising markets and a large short position in declining markets. But what would the partial hedger have done without the advantage of hindsight?

In order to determine the average rate of return resulting from use of the partial hedge, then, it was necessary to devise a set of decision rules that were themselves as free as possible of hindsight and could be applied in an equally unbiased manner. The procedure used in the present study was to: (1) Develop a set of equations, or decision models, to determine the number of common shares to sell short in any partial hedge situation; (2) apply the equations to historical price data; (3) compute the dollar profits and percentage rates of return resulting from this application.

\section{Developing the Equations}

The purpose of the equations developed in this section was to determine the number of common shares to sell short per bond purchased, so as to equate expected profits regardless of whether the stock price increased or decreased after engaging in the partial hedge transaction. Two basic situations can originally exist--either the bond's current conversion value is at or below the current intrinstc value, or current conversion value is above curpent intrinsic value. 
Current Conversion Value at or Below Current Intrinsic vaIue

Convertibles falling in this category will currently sell at intrinsic value plus some original speculative premium (possibly zero in some cases). In the equations covering such bonds, the following symbols are used:

$$
\begin{aligned}
& N=\text { number of common shares sold short per } \\
& X=\text { net dollar gain if stock price rises } \\
& \text { (a loss if } X \text { negative) } \\
& Y=\text { net dollar gain if stock price falls } \\
& \text { (a loss if } Y \text { negative) } \\
& \mathrm{n}=\text { number of common shares into which the } \\
& \text { bond is convertible } \\
& r=\text { expected dollar rise in price per share } \\
& \text { of common stock if stock rises } \\
& f=\text { expected dollar decline in price per } \\
& \text { share of common stock if stock declines } \\
& \text { (entered as a positive value) } \\
& S=\text { current market price per share of com- } \\
& \text { mon stock } \\
& B_{i}=\text { intrinsic value of bond (which in this } \\
& \text { situation also equals current market } \\
& \text { price) } \\
& u=\text { expected dollar increase }(t) \text { or decrease } \\
& (-) \text { in speculative premium if the stock } \\
& \text { price rises } \\
& \mathrm{d}=\text { expected dollar increase }(+) \text { or decrease } \\
& \text { (-) in speculative premium if the stock } \\
& \text { price declines } \\
& \mathrm{v}=\text { expected dollar increase }(t) \text { or decrease } \\
& (-) \text { in intrinsic value }
\end{aligned}
$$

Bonds whose conversion values are currently at or below intrinsic values can be categorized into three subsets:

Conversion value too far below intrinsic value.-- When the conversion value is so far below intrinsic value that the anticipated rise in stock price, $r$, will be insufficient to overcome the deficit, a loss will result if the stock price 
does, in fact, rise. That is, no profit will be earned on the bond and any accompanying short sale will result in a loss if the stock price rises. It is possible that an increase in speculative premium, $u$, or in intrinsic value, $v$, will provide an offset. One could, of course, speculate on changes in intrinsic value caused by changes in generally prevailing interest rates or in risk classification of the bond; but while such an undertaking could be pursued on its own merits, it should not be mixed, at least for testing purposes, with the partial hedge. As will be shown later in the chapter, the partial hedge is more sensitive to changes in speculative premiums, and a case could be made for admitting a rise in speculative premiums as a possible source of hedging profit. But for the sake of conservatism, the following policy statement can be formulated:

$$
\text { Folicy Statement } A \quad \begin{aligned}
& \text { If } r<\frac{B_{i}}{n}-S \\
& \text { Do Not Engage }
\end{aligned}
$$

("Do not engage" means, of course, that the partial. hedger should look elsewhere for hedging opportunity). Assuming the prospective transaction passes this test, two other basic situations may exist; the first is as follows.

New conversion value expected to exceed new intrinsic value if stock price rises.--This situation exists when Policy Statement $A$ is satisfied and when $v$ is negative or when $\mathrm{n}(\mathrm{r}+\mathrm{s})-\mathrm{B}_{i}>\mathrm{v}$ if $\mathrm{v}$ is positive. In this case, the gain, 
$X$, to be expected if the stock price rises is:

$$
\text { Equation } 1 \quad X=n(r+S)-B_{i}-N r+u
$$

And the gain, $Y$, to be expected if the stock price falls

is:

$$
\text { Equation } 2 \quad Y=N f+V+d
$$

It should be noted that the change in $\mathrm{v}$ does not appear in the $X$ equation. If $v$ is negative or else $n(r+s)-B_{i}>v$, the rise in stock price will push the price of the bond above its new intrinsic value, thus making $v$ irrelevant. A negative v--that is, a decline in intrinsic value--need concern the partial hedger only to the extent that the stock price falls rather than rises; and a rise is assumed in the $X$ equation.

In the $Y$ equation, which assumes a decline in stock price, any change in v--either plus or minus--will directly affect the amount of the profit, either favorably or adversely. The factor $v$ must, therefore, be included in the equation. Expected changes in speculative premium, $u$ or $d$, are always a source of concern.

Regardless of whether the price of the stock rises or falis, profits can be equated by setting $X=Y$ and solving for $\mathbb{N}$ :

$$
\begin{aligned}
& n(r+S)-B_{i}-N r+u=N f+v+d \\
& \text { Equation } 3 \quad N=\frac{n(r+s)-B_{i}+u-v-d}{r+f}
\end{aligned}
$$


Under the conditions stated thus far, the partial hedge will probabiy result in a profit (the probability of this occurrence depending mainly upon changes in $v, u$, and d). It should be emphasized, however, that under other conditions described later, losses can more readily develop. The $\mathbb{N}$ equation is designed only to equate profits regardless of whether the stock price rises or falls. It does not specify that the equated profits be positive. Therefore, immediately after applying any $N$ equation, such as Equation 3, the resulting $N$ should be fed back into either the $X$ or $Y$ equation to see if a positive profit results. Thus,

$$
\begin{array}{ll|}
\text { Policy Statement B } \quad \text { If } X \text { or } Y \leq 0 \\
\text { Do Not Engage }
\end{array}
$$

The partial hedger will, of course, dislike small profits as well as actual losses. But the decision on whether to engage of not is more complicated in this case. More will be said about this problem later.

Two additional, and probably obvious, policy statements might be mentioned before proceeding further:

$$
\begin{aligned}
& \text { Policy Statement } C \quad \begin{array}{c}
\text { If } N \leq 0 \\
\text { Do Not Engage }
\end{array} \\
& \text { Policy Statement } D \cdot \begin{array}{l}
\text { If } r \text { or } f=0 \\
\text { Do Not Engage }
\end{array}
\end{aligned}
$$

It is not necessary that both $r$ and $f$ be zero for this second policy statement to apply. If $r$ is zero, a straight 
short sale would be called for; if $f$ is zero, a straight bond or stock purchase; and if both $r$ and $f$ are zero, no transaction of any kind.

It is important to realize that when the partial hedger attempts to equate profits by setting $X=Y$ and solving for $\mathrm{N}$, he is expressing a complete lack of opinion on, and is indifferent to, the directional movement of the stock price, even though he may assign different values to $r$ and $f$. The partial hedger is saying, in effect, "I have no opinion on whether the market will rise or fall, and I do not care which happens; but I believe that if the stock rises, it will rise by $\$ 20$; on the other hand, if it falls it will fall by $\$ 30 "$ (or any other specific dollar figures the hedger selects, the exact magnitude being of considerable importance as will be shown later).

The complete lack of opinion on directional movement is conceptually quite different from a situation in which the investor assumes a 50 per cent chance of a stock price rise and a 50 per cent chance of a decline, even though the mathematical results are the same. This can be clarified by assuming a probability distribution other than $.5 / .5$. Let $k$ represent the probability of a rise, and $(1-k)$ the probability of a decline. To equate profits would require the equation $X=\left(\frac{k}{1-k}\right) Y$. But if the probability of . decline is greater than the probability of rise, and if the investor is not indifferent to the greater chance of decline, 
he would necessarily elect to sell a greater number of shares short in order to capitalize on the greater expectation of a falling market. The $N$ resulting from $X=\left(\frac{k}{(1-k)}\right) Y$, however, grows smaller as the probability of decline increases, not larger. In order to increase expected profits, the investor would have to use the "opposite" equation $X=\left(\frac{(1-k)}{k}\right) Y$. Thus, an attempt to equate profits is the inverse of the attempt to increase profits, with the single exception of the $.5 / .5$ probability distribution.

Although it is clearly possible in the mathematical sense to develop equations allowing different subjective probability distributions for directional movement of the stock price, to do so would represent a definite departure from the partial hedge philosophy; and the departure is one of concept, not simply one of degree. The partial hedger attempts to minimize risk associated with individual transactions (though he usually does not eliminate it) in return, perhaps, for a smaller profit over a series of transactions. Any attempt to increase profits by assuming greater risk makes the investor something other than a partial hedger.

If the hedger, instead of assigning different values to $r$ and $f$, should decide to use the somewhat less sophisticated approach of assuming that the potential rise will be the same in absolute amount as the potential decline, the $\mathrm{N}$ equation can be slightly simplified. The hedger must, however, still predict the dollar amount of the change. If $r=f=c$, where 
c denotes simply "change," the $\mathrm{N}$ equation showr above (Équation 3) can be rewritten as:

$$
\text { Equation } 4 \quad N=\frac{.5\left[n(c+s)-B_{i}+u-v-d\right]}{c}
$$

Equations 1 and 2 could, of course, also be rewritten, along with Policy Statement $A$ (which must still be employed along with Policy Statement $B$ ).

With one exception to be noted below, the partial hedger must, unfortunately, estimate the dollar amount of the potential rise and fall in stock price--ever if, as conjectured in Equation 4, the amount of the rise is expected to equal the amount of the fall. He is, however, freed from the task of predicting in which of the two directions the stock will move.

The hedger must also assign a value to $\mathrm{v}$, the change in intrinsic value. Even if credit-worthiness of the company is treated as a constant, this unfortunately still means making a forecast of interest rate changes. This may be an unmanageable task, forcing the hedger to use zero as the value of $v$. Fortunately, most partial hedge operations will be of fairly short duration so that drastic changes in $v$ may not occur prior to disengagement. The movement in general interest rates is not directly related to short-term changes in the price of a single stock, even though it may be possible to trace funadmental cyclical relationships between overall 
stock and bond prices. 3 Thus, the partial hedger might be safe in ignoring the factor $v$. He should think twice, however, before doing so during a period of unusually low interest rates, or duing a period of rapid change in rates. The partial hedger definitely cannot ignore the factors $u$ and $d$, because change in speculative premium is an inherent part of the hedging situation itself--that is, is functionally related to changes in stock prices. A method by which values for $u$ and $d$ can be estimated is discussed at a later point.

As mentioned previously, there is one set of conditions under which the stock price changes, $r$ and $f$, need not be predicted. This condition is the perfect (or ideal) partial hedge. Although the perfect partial hedge is not likely to exist in practice, a brief explanation may shed contrasting light on nonperfect hedges. The perfect hedge exists when there is no original speculative premium (probably denoting an imperfect market) and when:

$$
\begin{aligned}
r & =f=c \\
u & =0 \\
d & =0 \\
v & =0 \\
B_{i} & =n S(\text { that is, where the current price of the } \\
\text { bond }=\text { intrinsic value = conversion } & \text { value) }
\end{aligned}
$$

3 The historical pattern has been one in which a directional change in bond prices has been followed by a corresponding change in stock prices, although the interval between the two has varied considerably. Since 1947, the interval has ranged from 8 to 20 months. See "The Outlook, Appraisal of Current Trends in Business and Finance," The Wall Street Journal, XXXVIII (Nov. 7, 1966), 1 . 
So that, from Equation 4:

$$
N=\frac{.5\left[n(c+S)-B_{i}\right]}{c}
$$

Substituting $n S$ for $B_{i}$ and simplifying:

$$
\text { Equation } 5 \quad \mathrm{~N}=.5 \mathrm{n}
$$

This is simply a way of formalizing the fact, discussed on page 181, that in the ideal partial hedge, one would sell short exactly half the number of common shares into which the bond is convertible. In specifying that $B_{i}=n S$, however, the intrinsic value of the bond need not be the same as its face value. For example, $\$ 900=10(\$ 90)$ is equally as valid as $\$ 1000=10(\$ 100)$.

New intrinsic value expected to exceed new conversion value if stock price rises..-This is the third and last hedging situation within the general category of bonds whose conversion values are currently at or below intrinsic values. When Policy Statement $A$ has been satisfied, and when $v$ is positive, and when $n(r+s)-B_{i}<v$, then if the stock price rises the new intrinsic value of the bond will exceed the new conversion value of the bond, making the latter irrelevant. Thus, the $X$ equation would become:

$$
\mathrm{X}=\mathrm{v}-\mathrm{Nr}+\mathrm{u}
$$

The $Y$ equation would not change. It would still be:

$$
Y=N f+v+d
$$


Setting $X=Y$ and solving for $N$ results in:

$$
N=\frac{u-d}{r+f}
$$

Obviously, if (u - d) is zero, $\mathbb{N}$ would be zero, signaling "do not engage." If $(u-d)$ is zero, profit cannot be equated with any positive $N$, and a positive $N$ will anways produce a loss in the $X$ equation except to the extent that the loss is offset by a rise in intrinsic value, v. If the intrinsic value is the only source of profit, the investor would obviously assume less risk and earn more profit with a straight bond purchase. Thus, the "do not engage" signal is correct.

A positive (u - d) will result in a positive N. But is there any logic to engaging in the partial hedge solely on the basis of anticipated changes in the speculative premium (or on the basis of combined change in $v$ and in the speculative premium)? While there may be some justification, both mathematically and in terms of practical investor expectations, such an undertaking is likely to produce only a very small expected profit, if any, other than the gain in intrinsic value, and is incidental to the main objective of the partial hedge. Therefore:

$$
\text { Policy Statement } E\left[\begin{array}{l}
I f v i j+\text { and } \\
n(r+s)-B_{i}<v \\
\text { Do Not Engage }
\end{array}\right.
$$


Current Conversion Value Above Current

Intrinsic Value

After the common stock rises above the point at which

$n S>B_{i}$, a convertible will sell, not at intrinsic value plus

a speculative premium, but at conversion value plus a specu-

lative premium (with a zero speculative premium in some cases).

Two additional symbols must be introduced to handle this

category of bonds:

$$
\begin{aligned}
B_{C}= & \text { current market price of bond } \\
P_{0}= & \text { dollar amount of original speculative } \\
& \text { premium (the difference between } B_{c} \\
& \text { and conversion value ns) }
\end{aligned}
$$

Within the general category of bonds whose conversion values are currently above intrinsic values, three subsets can exist, as follows.

Conversion value not expected to decline to intrinsic value if stock price falls.-This condition exists when $f<\frac{B_{c}-B_{i}-P_{0}}{n}$. In this case, the decline in stock price will be insufficient to bring into play one of the basic requirements of the partial hedge, namely that the intrinsic value of the bond act as a "floor" to cushion losses on the bond when the stock price declines. Thus, the following policy statement applies:

Policy Statement F

$$
\begin{gathered}
\text { If } f<\frac{B_{c}-B_{i}-P_{0}}{n} \\
\text { Do Not Engage }
\end{gathered}
$$


New conversion value expected to exceed new intrinsic value if stock price rises...-If the new conversion value is expected to exceed the new intrinsic value--that is, if: : $v$ is negative or if $n(r+S)-B_{i}>v$ when $v$ is positive, the hedging situation is a basically desirable one. In this case, the $X$ equation must be rewritten as:

$$
\text { Equation } 6 \quad \mathrm{X}=\mathrm{n}(\mathrm{r}+\mathrm{S})-\mathrm{B}_{\mathrm{c}}-\mathrm{Nr}+\mathrm{u}+\mathrm{P}_{\mathrm{o}}
$$

The $Y$ equation becomes:

$$
\text { Equation } 7 \quad Y=N f-n S+B_{i}+v+d
$$

Setting $X=Y$ and solving for $N$ :

Equation 8

$$
N=\frac{n(r+2 S)-B_{c}-B_{i}+P_{0}+u-d-v}{r+f}
$$

Policy Statements $B, C$, and $D$ should always be applied.

New intrinsic value expected to exceed new conversion value if stock price rises.--As was true of the similar situation discussed previously, this is not a basically desirable partial hedge situation, even though small profits may occasionally result. The condition denotes either a small increase in conversion value, which is undesirable, or else a large rise in intrinsic value that might be pursued on its own merits but not combined with a short sale. Thus :

Policy Statement G If $v$ is + and
$n(r+s)-B_{i}<v$
Do Not Engage 
Policy Statement $G$ is identical to Policy Statement $E$ and is repeated here only for convenience.

\section{Summary of Equations}

The following is a step-by-step summary of the procedure to follow in applying the equations developed in this chapter.

First, the current intrinsic value and current conversion value of the bond must be determined. If the conversion value is at or below intrinsic value, the steps under $A$ below should be followed; if above intrinsic value, the steps under $B$ should be followed. After applying any $N$ equation, the resulting $N$ should be fed into the appropriate $X$ or $Y$ equation to check for negative or small expected profits. (Computing both $X$ and $Y$ to see if they are equal provides a check against computational errors). If $\mathrm{N}$ is zero or negative, the investor should not engage in the transaction.

A. Current Conversion Value at or Below Current Intrinsic Value

1. Predict $r$ and $f$. If either is zero, do not engage and proceed no further.

2. If $r<\frac{B_{i}}{n}-S$, do not engage and proceed no further.

3. If $v$ is positive and $n(r+S)-B_{i}<v$, do not engage and proceed no further.

4. If $v$ is negative or if $n(r+S)-B_{i}>v$ when $V$ is positive, apply one of the following $N$ equations, feeding any positive $N$ into the 
$X$ and/or $Y$ equations shown:

(a) If $\mathrm{r}=\mathrm{f}=\mathrm{c} ; \mathrm{P}_{0}=0 ; \mathrm{u}=0 ; \mathrm{d}=0$;

$\mathrm{v}=0 ;$ and $B_{i}=n S$ :

\begin{tabular}{l|}
$\mathrm{N}=.5 \mathrm{n}$ \\
$\mathrm{X}=\mathrm{cN}$ \\
$\mathrm{Y}=\mathrm{cN}$ \\
\hline
\end{tabular}

(b) If the conditions in (a) are not satisfied:

$$
\begin{array}{|l}
N=\frac{n(r+s)-B_{i}+u-d-v}{r+f} \\
X=n(r+s)-B_{i}-N r+u \\
Y=N f+v+d
\end{array}
$$

B. Current Conversion Value Above Current Intrinsic Value

1. Predict $r$ and $f$. If either is zero, do not engage and proceed no further.

2. If $f<\frac{B_{c}-B_{i}-P_{0}}{n}$, do not engage and proceed no further.

3. If $\mathrm{v}$ is positive and $n(r+s)-B_{i}<v$, do not engage and proceed no further.

4. If $v$ is negative or $n(r+s)-B_{i}>v$ when $v$ is positive:

$$
\begin{aligned}
& N=\frac{n(r+2 S)-B_{c}-B_{i}+P_{0}+u-d-v}{r+f} \\
& X=n(r+S)-B_{c}-N r+u+P_{0} \\
& Y=N f-n S+B_{i}+d+v
\end{aligned}
$$




\section{Additional Comments}

Some additional comments regarding the development and use of the equations are worth noting. First of all, in regard to the $\mathrm{n}$ in the equations, no provision was made for the relatively few bonds whose conversion features involve an additional cash payment. Secondly, as mentioned in previous chapters, even in the case of regular conversion terms, $n$ is frequently not constant over time. The partial hedger must, of course, remain on guard against declines in the number of shares into which the bond is convertible. Thirdly, the size of $n$ will have a direct bearing on the profit potential of the partial hedge, other parameters remaining the same. Using the perfect partial hedge as an example, it is apparent that since $N=.5 n$ and $X=Y=c N$, then $X=Y=.5 \mathrm{cn}$. If $c$ is held constant, $\frac{\Delta X}{X}=\frac{\Delta n}{n}$ or $\frac{\Delta Y}{Y}=\frac{\Delta n}{n}$. That is, any percentage change in $n$ will invoke the same percentage change in $X$ or $Y$. This means that if the investor's funds are limited, and he is faced with choosing from among several alternative bonds, then-m other factors remaining the same--he should choose the bonds that are convertible into the greatest number of shares. The $X$ and $Y$ equations, however, take this factor into account automatically. It should also be pointed out that "other things" will not usually be equal; this is especially true of $r$ and $f$. 
Another important point involving the development of the equations is that no attempt was made to build commission charges into the $\mathrm{X}, \mathrm{Y}$, and $\mathrm{N}$ equations, because to do so wolld require an arbitrary assumption as to the size of the transactions and probably a set of equations requiring some programing or iterative technique to solve. It seemed more reasonable to avoid this complexity even though $\mathrm{X}$ will differ slightly from $Y$ after subtracting commissions.

The tax problem is equally complex because of the various assumptions that can be made about the tax rate, the number of transactions engaged and disengaged during a tax year, and the outcome of each. To use a simple example, if the investor completes only one transaction during the year, losing $\$ 100$ on the short sale and making $\$ 200$ on the bond, and if his regular tax rate is 50 per cent, and assuming a long-term capital gain on the bond, the income tax would be $\$ 25$ (25 per cent of the net gain of \$100). If, instead, he breaks even on the bond and makes $\$ 100$ on the short sale, the tax would be $\$ 50$ (all short sale profits are usually treated as short-term capital gains for tax purposes). If the investor completes both of these two transactions within a tax year, the short sale gain on one would offset the short sale loss on the other, reducing the average tax per transaction to $\$ 25$ again. 5

Investor's Tax Kit, 1966-67 edition, Merrill Lynch, Pierce, Fenner and Smith, Inc., N. Y. Another complication 
Because of the problems involved in trying to compute taxes and commissions, the goal of equating true expected net profits in the event of either a rise or fall in stock prices could not be achieved. Commissions and taxes can, however, be evaluated on an after-the-fact basis. Additional comments on this appear later in the chapter.

Dividends and interest were also ignored in developing the equations. As will be shown shortly, interest received on the bonds will, on average, more than offset dividends paid on the short sales and will, additionally, provide an off set to commission charges.

\section{Applying the Equations}

In using the equations to test the profitability of the partial hedge, the general procedure was to apply the appropriate $N$ equations to historical price data on convertibles and matching stocks, hypothetically engaging in all transactions in wich a positive profit of any size was indicated by the $X$ and $Y$ equations. (Later on, a more selective strategy was followed ragarding the size of $X$ and $Y$ ). Rules were established to determine when each transaction was to be terminated. Rates of return, expressed as noncompounded annual yields, were then computed to gauge the general

stems from the fact that federal tax laws aliow convertible bondholders, at their option, to amortize premiums paid above either face on conversion value, whichever premium is less. See Prentice-Hall's Capital Adjustments, pp. 9201-03. 
profitability of the partial hedge technique and to form judgments on the rationality of the technique and the market enviroment in which it operates.

\section{Collection of $\frac{\text { Data }}{\text { of }}$ and $\frac{\text { Computation }}{\text { Paraters }}$}

The convertibles selected for the application are shown in the appendix. Only industrial issues listed on the New York Stock Exchange in late September, 1966, were used, and from this basic list the following were eliminated: Bonds rated less than $B a$ by Moody's, those whose stocks sold in a very low price range (under $\$ 10$ ), bonds with special or unusual conversion features, and bonds on which historical bond or stock data could not be collected or adjusted with accuracy. 6 In all, thirty-six bonds and thirty-six matching stocks were used.

Using the North Texas State University microfilm file of Wall Street Journal issues, mid-month closing prices of bonds $\left(B_{C}\right)$ and stocks $(S)$ were recorded (varying slightly from mid-month if necessary to get both a bond and a stock price on the same day). In the case of bonds issued prior to 1956, mid-month prices from January, 1956, to November, 1966, were recorded. In the case of bonds issued after

6 The investigation of the partial hedge was completed prior to that involving the other techniques discussed in the dissertation. This accounts for the 1966 sampling date. There have been no developments since then that would materially alter the main conclusions reached in the study. 
January, 1956, the tabulation commenced when the bond first entered into active secondary trading and continued through mid-November, 1966. All stock prices were adjusted for stock splits, stock dividends, and rights, commensurate with the bond indenture dilution provisions.

Intrinsic values $\left(B_{i}\right)$---Intrinsic values for each bond were computed at six-month intervals in most cases, with smaller intervals during years when general interest rates changed substantially. Moody's yields were used as prevailing rates on bonds rated Baa or higher. 7 For bonds rated Ba, an analysis of various advisory service evaluations of. intrinsic value indicated that a premium of about .40 per centage points above Moody's Baa yields would approximate the prevailing yields on bonds rated $\mathrm{Ba}$. Intrinsic values were then computed from a table of bond values. Intrinsic values within the standard six-month intervals were obtained by interpolation.

Original speculative premiums $\left(P_{0}\right)$.--Given the conversion feature of each bond, the intrinsic value, and the current market price, the original speculative premium above either intrinsic value or conversion value (whichever was highest) was easily computed.

7Moody's Industrial Manual, Moody's Investors Service, Inc., N. Y., June, 1966, p. $233 \mathrm{ff}$, , and supplementary reports 
Change in intrinsic value (v).--In order to eliminate any possible use of hindsight, the assumption was made that $\mathrm{v}=\mathrm{o}$ in all applications of the equations. (This assumption may also be consistent with actual behavior on the part of bond investors).

Predicting changes in stock price (r and f)--Here, again, it was preferable that no favorable bias be introduced because of the availability of the historical price data. Therefore, a purely mechanical price change forecaster was devised. For each historical year during which an $\mathbb{N}$ equation was applied to a set of stock and bond prices, it was assumed that $r=f=c$ and that the subsequent price change, $c$, would equal the average spread between the yearly high and low closing prices during the preceding four years. (This required picking up additional stock price data going back as far as 1952). This made the mechanical forecaster a moving average that always included the four years just prior to the year of application of the $N$ equations.

Predicting Changes in Speculative Premiums An especially arduous task in applying the equations was finding some way to predict changes in speculative premiums, $u$ and $d$. To make these predictions, it was necessary to find the pattern of change in the historical data itself. This was the only violation of the "no hindsight" rule, but an absolutely necessary one. It was believed that some 
correlation must exist between the size of the speculative premium and the difference between conversion value and intrinsic value. If conversion value starts well below intrinsic value, the speculative premium should increase as the conversion value rises, up to some point beyond which the premium should begin to recede. An analysis of 396 sets of bond prices, intrinsic values, and conversion values disclosed the average pattern shown in Figure 3. (The sets were selected by starting from the first recorded set for each of the thirty-six bonds and picking sets at six-month intervals thereafter). As indicated by Figure 3, when conversion value ranged from 50 to 59 per cent of intrinsic value, the speculative premium averaged 6.5 per cent over intrinsic value. The premium increased as the bonds increased in conversion value, reaching a peak of 20.1 per cent over intrinsic value when conversion ranged from 90 to 99 per. cent of intrinsic value. The premium declined thereafter. For example, when conversion value ranged from 120 to 129 per cent of intrinsic value, the premium was only 7.3 per cent over conversion value. The pattern of rising, then falling, premiums was confirmed. This pattern agrees in a general way with the findings of $G$. I. Levy, who states that convertibles selling from $\$ 1000$ to $\$ 1150$ contain a premium of from 10 to 20 per cent over conversion value, while bonds selling above $\$ 1250$ to $\$ 1400$ contain little if any premium. ${ }^{8}$ It is 


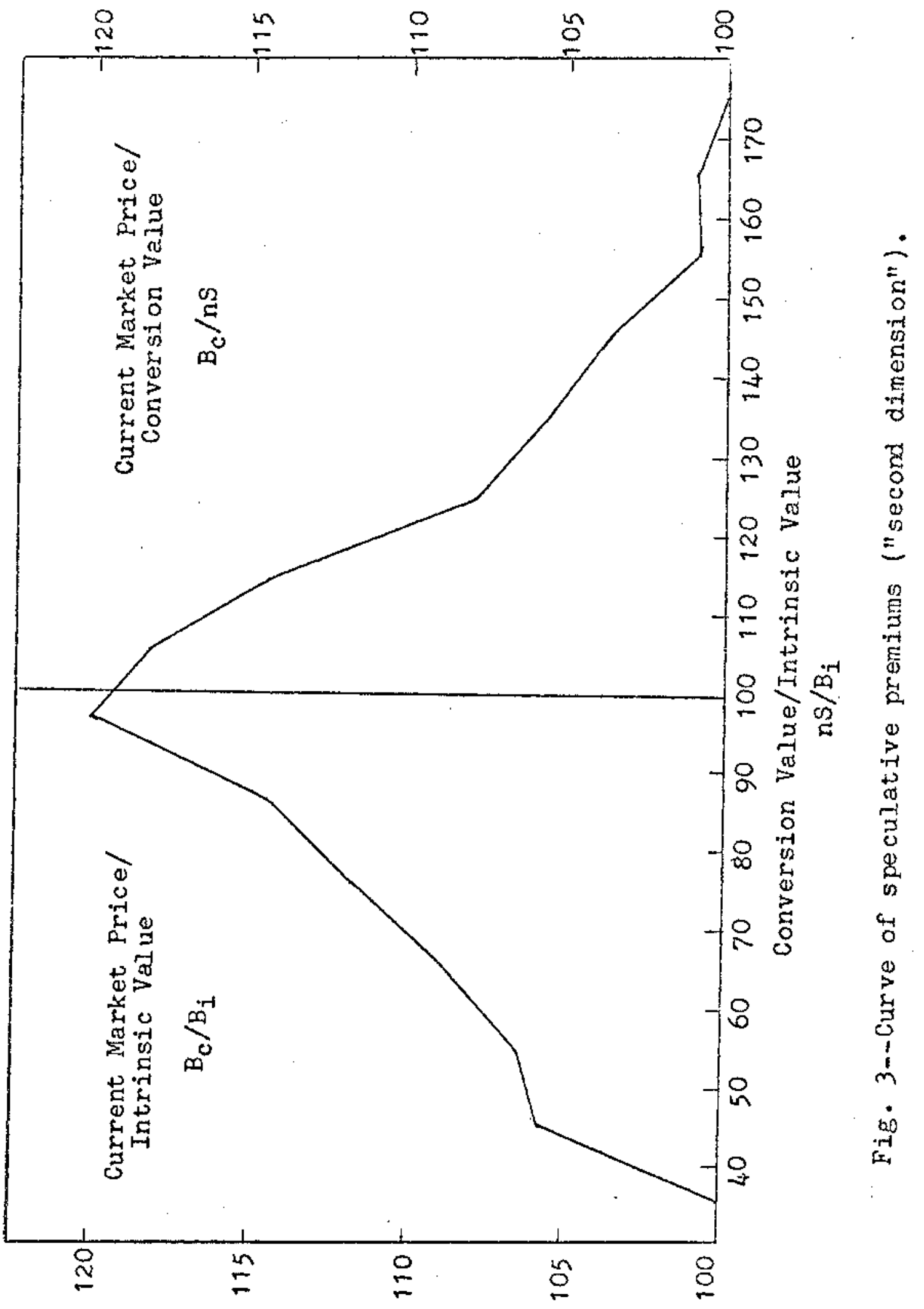


impossible, however, to make an exact comparison with Levy's absolute dollar guidelines (which furnish only an approximation).

As noted in the preceding chapter, the level of speculative premiums is a two-dimensional phenomenon--one having to do with the general level of speculative premiums over time and the other with the specific level on an individual bond. The general level of speculative premiums is affected by external stimuli as well as by general stock price movements. The specific level, while also subject to external stimuli, is more directly affected by the ratio of conversion value to intrinsic value of the individual bond. It is, of course, this second dimension on which the present discussion centers. It is important to realize, however, that the first dimension was assumed constant in developing the curve in Figure 3, when in reality the general level of speculative premiums has declined over much of the time period involved in the study. Ideally, a forecast of future speculative premiums on an individual convertible should take into account anticipated changes in the general level of premiums.

Although the influence of the "first dimension" of speculative premiums was not isolated in the present study, the curve in Figure 3 enabled a reasonable prediction of

Investor," Commercial and Financial Chronicle, Vol. 194 (July 20, 1961), pp. 278-9. 
$u$ and $d$ for use in the $N$ equations. In the case of $u$, after computing the stock price change, $c$, the new conversion value following an assumed rise in stock price could be determined, and its ratio to the intrinsic value calculated. Figure 3 then supplied the percentage to multiply by either the intrinsic value or the conversion value. The resulting dollar premium was compared with the original premium, $P_{0}$, with the difference between the two being $u$. The values for d were computed in similar fashion.

\section{Other Procedural Considerations}

There were several other procedural questions. For one thing, in order to keep the number of applications of the $N$ equations within reasonable bounds, and in order to avoid two or more applications to basically the same hedging situation, a timing rule was needed. For each bond and matching stock, the appropriate $\mathrm{N}$ equation was applied to the first recorded set of historical prices (if not ruled out by a policy statement). Successive applications were made only after either one of two conditions had been satisfied: (1) The stock price had changed by fifteen per cent or more, or (2) six months had elapsed.

No attempt was made initially to rule out transactions on the basis of the size of $X$ and $Y$, except to exclude (that is, not engage in) transactions with negative indicated profits. The reason was that one purpose of the applications 
test itself was to see if any correlation existed between the size of anticipated profits and the size of actual profits.

A rule also had to be devised to decide when transactions would be terminated. After the $N$ (and $X$ and $Y$ ) equations gave an "engage" signal, which occurred a total of 165 times, the problem was to eliminate the use of ex post knowledge about prices in the termination decisions. Two termination rules were established and the results of each compared in the final evaluation. The first rule (called the "target rule") specified that a transaction be terminated when the predicted price change--c, either a rise or a fall--was reached, or when twenty-four months had elapsed, whichever occurred first. The second rule (called the "filter mile") specified that the transaction be kept open past the target price level until each successive high or low had reversed itself by as much as ten per cent; if the target price was not reached within twenty-four months, the transaction was terminated then.

All initial computations and tabulations were on a beforetax and before-commission basis, for reasons given earlier.

\section{Results of the Application}

The initial results of the test using the target rule are summarized in Table XIX, which includes the 142 transactions that were completed (that is, terminated) under this 
TABLE XIX

ALL PARTIAL HEDGE TRANSACTIONS COMPLETED

UNDER THE TARGET RULE

\begin{tabular}{|c|c|c|c|c|c|c|}
\hline Description & $\begin{array}{l}\text { No. of } \\
\text { Transac- } \\
\text { tions }\end{array}$ & $\begin{array}{l}\text { Total } \\
\text { Invest- } \\
\text { ment }{ }^{2}\end{array}$ & $\begin{array}{l}\text { Total } \\
\text { Profit }\end{array}$ & $\begin{array}{l}\text { Avg. } \\
\text { No. of } \\
\text { Months }\end{array}$ & $\begin{array}{l}\text { Annual } \\
\text { Yield }\end{array}$ & $\begin{array}{c}\text { Predict } \\
\text { ed } \\
\text { Profit }\end{array}$ \\
\hline $\begin{array}{l}\text { Air Reduction } \\
\text { American Dist. } \\
\text { American M \& F } \\
\text { Armour } \\
\text { Ashland Oil } \\
\text { Aurora } \\
\text { Avco } \\
\text { Beaunit } \\
\text { Celanese } \\
\text { Collins Radio } \\
\text { Comb. Engineer. } \\
\text { Cont. Baking } \\
\text { Cop. Steel } \\
\text { Crow.-Collier } \\
\text { Dow Chemical } \\
\text { Dresser Ind. } \\
\text { Food Fair } \\
\text { Gen. Amer. Oil } \\
\text { General Instru. } \\
\text { General Time } \\
\text { Grace } \\
\text { Granite C. Steel } \\
\text { Hunt Foods } \\
\text { Int. Tel. \& Tel. } \\
\text { Litton } \\
\text { Vacy } \\
\text { Northrop } \\
\text { Olin. Math. } \\
\text { Oxford Paper } \\
\text { Phillips Pet. } \\
\text { Rohr } \\
\text { Scott Paper } \\
\text { Sinclair } \\
\text { Stevens, J. P. } \\
\text { United Aircraft } \\
\text { Xerox }\end{array}$ & $\begin{array}{c}5 \\
6 \\
\text { None } \\
2 \\
3 \\
1 \\
6 \\
1 \\
\text { None } \\
2 \\
15 \\
6 \\
7 \\
3 \\
3 \\
5 \\
10 \\
6 \\
1 \\
1 \\
\text { None } \\
\text { None } \\
\text { None } \\
2 \\
\text { None } \\
\text { None } \\
10 \\
9 \\
3 \\
9 \\
12 \\
7 \\
4 \\
\text { None } \\
3 \\
\text { None }\end{array}$ & 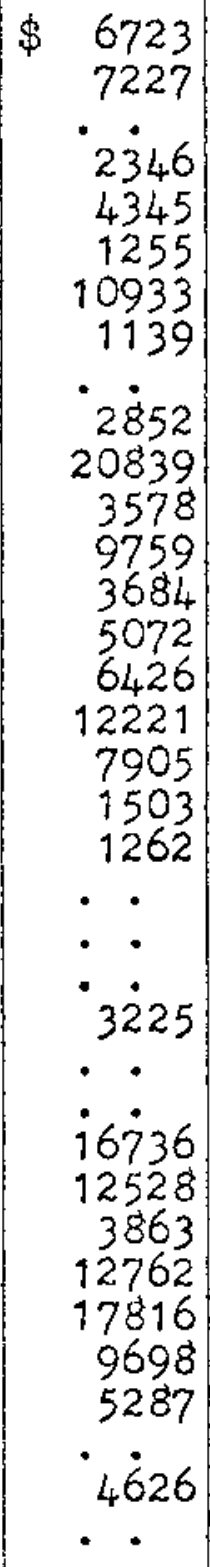 & 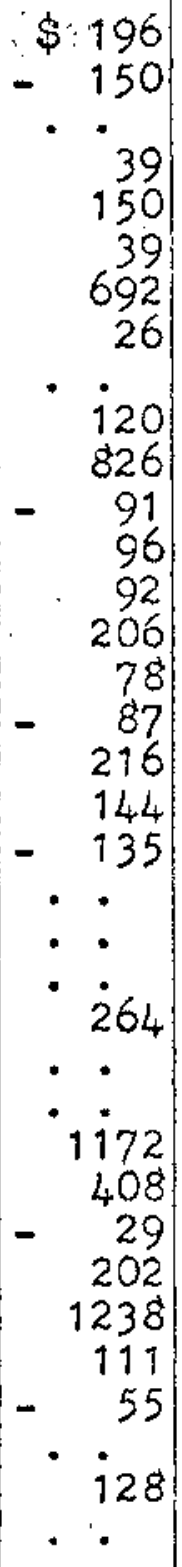 & $\begin{array}{l}21.4 \\
24.0 \\
13.0 \\
10.2 \\
3.0 \\
12.3 \\
3.0 \\
.6 .0 \\
13.7 \\
17.8 \\
13.4 \\
7.9 \\
10.9 \\
11.4 \\
17.2 \\
20.5 \\
1.0 \\
23.0 \\
.0 \\
.0 \\
.0 .0 \\
4.0 \\
i 1.0 \\
20.1 \\
15.8 \\
21.4 \\
12.6 \\
16.6 \\
15.5 \\
i 0.2 \\
. \quad .\end{array}$ & 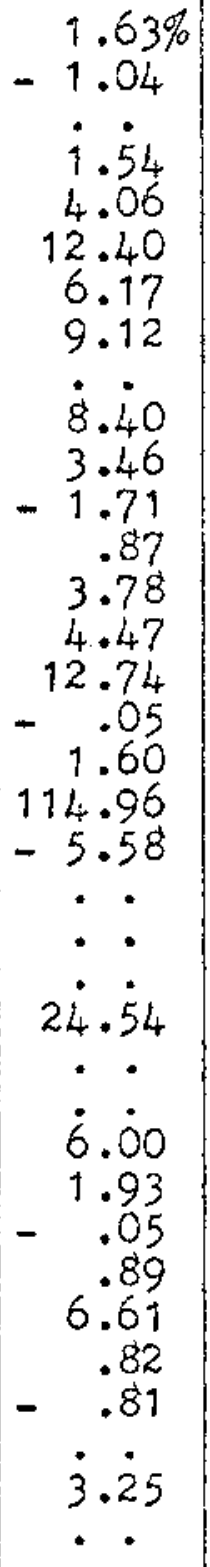 & 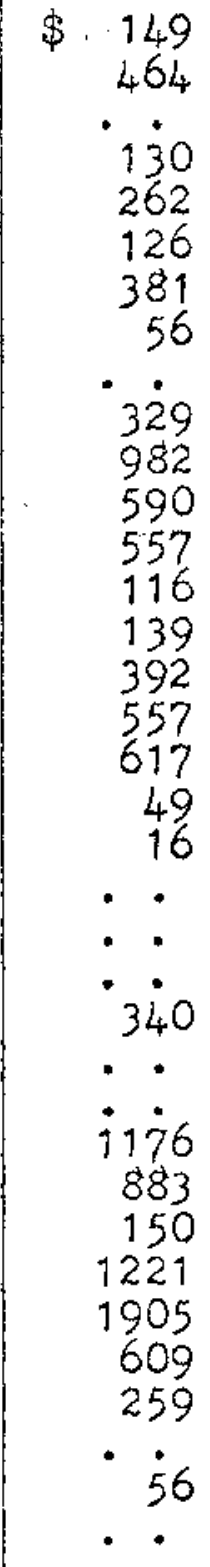 \\
\hline Total & 142 & $\$ 195610$ & $\$ 5896$ & 15.3 & $2.37 \%$ & $\$ 12511$ \\
\hline
\end{tabular}

*Based on purchasing one bond per transaction, and assuming $70 \%$ margin requirement on accompanying short sale. 
TABLE XX

ALL PARTIAL HEDGE TRANSACTIONS COMPLETED UNDER THE FILTER RULE

\begin{tabular}{|c|c|c|c|c|c|c|}
\hline Description & $\begin{array}{l}\text { No of } \\
\text { Transac- } \\
\text { tions }\end{array}$ & $\begin{array}{c}\text { Total } \\
\text { Invest } \\
\text { ment; }\end{array}$ & $\begin{array}{l}\text { Total } \\
\text { Profit }\end{array}$ & $\begin{array}{l}\text { Avg. } \\
\text { No. of } \\
\text { Months }\end{array}$ & $\begin{array}{l}\text { Annual } \\
\text { Yield }\end{array}$ & $\begin{array}{l}\text { Predict- } \\
\text { ed } \\
\text { Profit }\end{array}$ \\
\hline $\begin{array}{l}\text { Air Reduction } \\
\text { American Dist. } \\
\text { American M \& F } \\
\text { Armour } \\
\text { Ashland Oil } \\
\text { Aurora } \\
\text { Avco } \\
\text { Beaunit } \\
\text { Celanese } \\
\text { Collins Radio } \\
\text { Comb. Engineer. } \\
\text { Cont. Baking } \\
\text { Cop. Steel } \\
\text { Crow.-Coliier } \\
\text { Dow Chemical } \\
\text { Dresser Ind. } \\
\text { Food Fair } \\
\text { Gen. Amer. Oil } \\
\text { General Instr. } \\
\text { General Time } \\
\text { Grace } \\
\text { Granite C. Steel } \\
\text { Hunt Foods } \\
\text { Int. Tel. \& Tel. } \\
\text { Litton } \\
\text { Macy } \\
\text { Northrop } \\
\text { Olin Math. } \\
\text { Oxford Paper } \\
\text { Philips Pet. } \\
\text { Rohr } \\
\text { Scott Paper } \\
\text { Sinclair } \\
\text { Stevens, J. P. } \\
\text { United Aircraft } \\
\text { Xerox } \\
\text { Gril }\end{array}$ & $\begin{array}{c}5 \\
6 \\
\text { None } \\
\text { None } \\
3 \\
\text { None } \\
6 \\
\text { None } \\
\text { None } \\
2 \\
15 \\
3 \\
7 \\
3 \\
3 \\
5 \\
9 \\
6 \\
1 \\
1 \\
\text { None } \\
\text { None } \\
\text { None } \\
2 \\
\text { None } \\
\text { None } \\
10 \\
9 \\
3 \\
9 \\
12 \\
7 \\
4 \\
\text { None } \\
3 \\
\text { None }\end{array}$ & 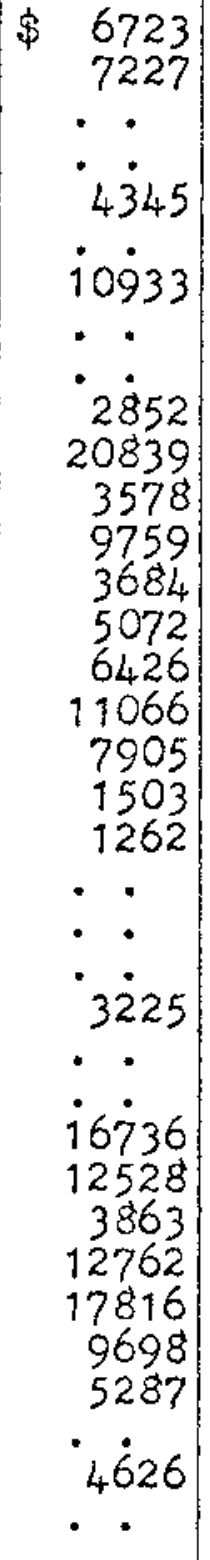 & $\begin{array}{c}-\$ 40 \\
-\quad 150 \\
\cdot \\
750 \\
1022 \\
\cdot \cdot \\
\cdot 173 \\
742 \\
49 \\
30 \\
111 \\
220 \\
168 \\
127 \\
218 \\
19 \\
114 \\
\cdot . \\
\cdot . \\
734 \\
\cdot . \\
856 \\
151 \\
68 \\
181 \\
2738 \\
115 \\
19 \\
1258 \\
\cdot\end{array}$ & 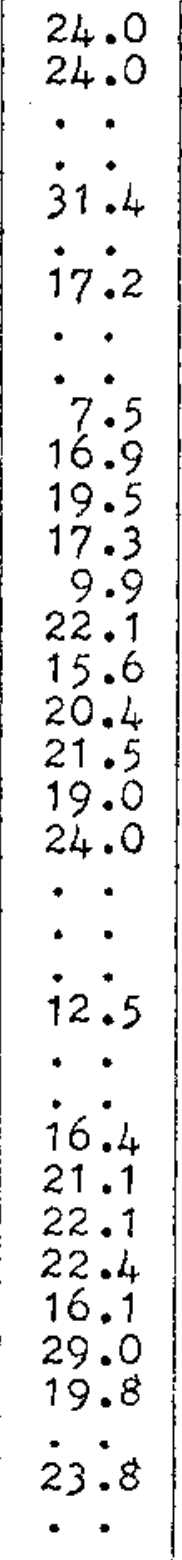 & 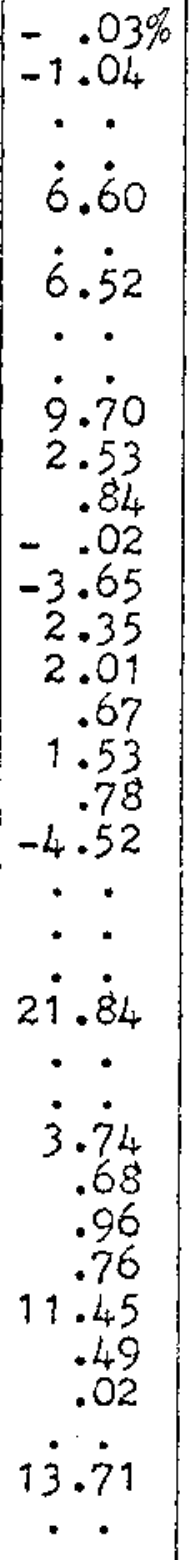 & 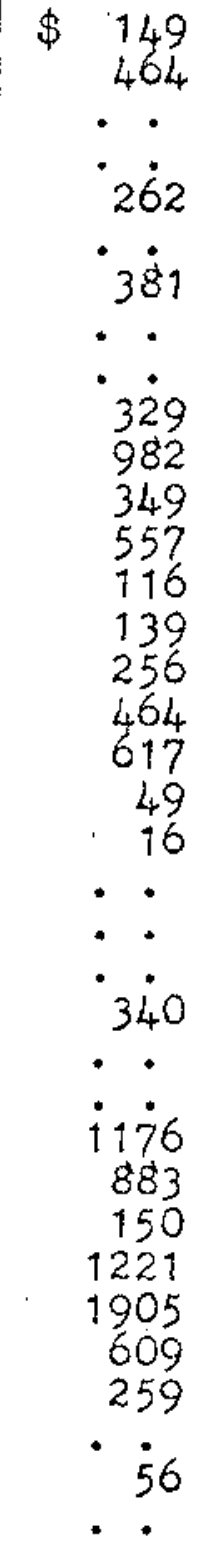 \\
\hline Total & 134 & $\$ 189715$ & $\$ 9163$ & 19.4 & 2.99 & $\$ 11729$ \\
\hline
\end{tabular}

*Based on purchasing one bond per transaction, and assuming $70 \%$ margin requirement on accompanying short sale. 
rule. Table $X X$ shows the 134 transactions that were completed under the filter rule. In both cases, no attempt was made to exclude transactions whose originally indicated profits were small. Total investment is based on the assumption of a seventy per cent short sale margin, with stocks "loaning flat," and assuming that the hedger purchases one $\$ 1000$ denomination bond per transaction. In both tables, about 43 per cent of the transactions were terminated at stock prices below the original level, and 57 per cent above.

The annual yield figures in both tables are small. The overall annual yield was 2.37 per cent under the target rule, but did increase significantly to 2.99 per cent under the filter mile. The small percentages, however, indicate a need for further refinement of the partial hedge technique before it can be declared rational.

\section{A Measure of Risk}

Table XXI shows the distribution of all terminated transactions by size of dollar gain or loss, under each of the two termination rules. Expressed in terms of probabilities, there was about a 75 per cent chance of gain under both termination rules, and a 25 per cent chance of loss. However, there was only about a 3.5 per cent chance of loss exceeding $\$ 50$ per transaction, with approximately a 44 per cent chance of a gain in excess of $\$ 50$. The largest single loss was $\$ 200$ and there were only seven losses in excess of $\$ 100$. 
Aside from one exceptional gain of $\$ 1025$, there were 16 gains greater than $\$ 200$, with two exceeding $\$ 500$ (the larger of the two being $\$ 553$ ).

\section{TABLE XXI}

SIZE DISTRIBUTION OF GAINS AND LOSSES, ALL COMPLETED PARTIAL HEDGE TRANSACTIONS

\begin{tabular}{|c|c|c|c|c|}
\hline \multirow[b]{2}{*}{$\begin{array}{c}\text { Size of Gain or } \\
\text { Loss Per } \\
\text { Transaction }\end{array}$} & \multicolumn{2}{|c|}{ Target Rule } & \multicolumn{2}{|c|}{ Filter Fule } \\
\hline & $\begin{array}{l}\% \text { of Tran- } \\
\text { sactions } \\
\text { in Each } \\
\text { Category }\end{array}$ & $\begin{array}{l}\text { Accumu- } \\
\text { lated } \\
\%\end{array}$ & $\begin{array}{l}\text { \% of Tran- } \\
\text { sactions } \\
\text { in Each } \\
\text { Category }\end{array}$ & $\begin{array}{l}\text { Accumu- } \\
\text { lated } \\
\%\end{array}$ \\
\hline $\begin{array}{l}\text { Gains } \\
\$ 200 \text { or more } \\
175-199 \\
150-174 \\
125-149 \\
100-124 \\
75-99 \\
50-74 \\
25-49 \\
0-24\end{array}$ & $\begin{array}{c}2.8 \% \\
2.1 \\
.7 \\
4.9 \\
10.6 \\
6.3 \\
17.6 \\
16.3 \\
13.4\end{array}$ & $\begin{array}{l}2.8 \% \\
4.9 \\
5.6 \\
10.5 \\
21.1 \\
27.4 \\
45.0 \\
61.3 \\
74.7\end{array}$ & $\begin{array}{r}11.9 \% \\
1.5 \\
2.2 \\
.7 \\
9.0 \\
6.0 \\
11.9 \\
14.9 \\
17.2\end{array}$ & $\begin{array}{l}11.9 \% \\
13.4 \\
15.6 \\
16.3 \\
25.3 \\
31.3 \\
43.2 \\
58.1 \\
75.3\end{array}$ \\
\hline $\begin{array}{l}\text { Losses } \\
\$ 1-25 \\
26-50 \\
51-75 \\
76-100 \\
101-125 \\
126-150 \\
151-175 \\
176-200\end{array}$ & $\begin{array}{c}16.3 \% \\
3.4 \\
2.1 \\
.7 \\
2.1 \\
.0 \\
.7 \\
.0\end{array}$ & $\begin{array}{l}91.0 \% \\
94 \cdot 4 \\
96.5 \\
97.2 \\
99.3 \\
99.3 \\
100.0 \\
100.0\end{array}$ & $\begin{array}{r}12.0 \% \\
5.2 \\
4.6 \\
.7 \\
1.5 \\
.0 \\
.0 \\
.7\end{array}$ & $\begin{array}{l}87.3 \% \\
92.5 \\
97.1 \\
97.8 \\
99.3 \\
99.3 \\
99.3 \\
100.0\end{array}$ \\
\hline $\begin{array}{l}\text { Average Invest- } \\
\text { ment Per } \\
\text { Transaction }\end{array}$ & \multicolumn{2}{|c|}{$\$ 1377$} & \multicolumn{2}{|c|}{$\$ 1416$} \\
\hline
\end{tabular}

The risk of substantial loss in the partial hedge is obviously quite small. This is not accidental, of course, 
since the technique itself is tailor-made for use by riskaverting investors. Some modification in the technique is needed, however, to overcome the small overall rates of return on investment.

\section{Refining the Technique}

There are three basic ways in which the rates of return might be improved. One is a weeding out of small expected profits as revealed by the $X$ and $Y$ equations, combined with elimination of the least profitable termination rule. The second is through the use of more heavily margined comnitments which, in effect, compromise somewhat on the low-risk aspect of the partial hedge for the sake of additional profit. The third is restriction of partial hedge commitments to periods in which intrinsic values remain stable (or rise) rather than declining as they did during the period covered by the study.

In connection with the first of these two approaches, Table XXII was constructed to include only the 46 completed transactions with originally indicated profits of $\$ 100$ or more each. These selections were taken only from the transactions terminated under the filter rule, the more promising of the two rules as indicated by Tables XIX and XX.

There is little indication that the $X$ and $Y$ equations are capable of much further meaningful selection. Under the filter rule, the 20 completed transactions with originally expected profit of $\$ 150$ or more each, produced an overall 
yield of 7.04 per cent; and the 14 transactions with originally expected profit of $\$ 175$ or more yielded 7.74 per cent. But these groups were heavily influenced by one transaction that produced an exceptionally large profit (Rohr Aircraft, $\$ 1025)$. After removing this one transaction, the $\$ 150$ and $\$ 175$ yields drop back to 5.02 per cent and 4.76 per cent, respectively. The $\$ 100$ yield shown in Table XXII drops to 4.22 per cent with the one exceptional transaction removed, and the nonselective yield of 2.99 per cent in Table XX drops to 2.82 per cent.

\section{TABLE XXII}

SELECTED PARIIAL HEDGE TRANSACTIONS COMPLETED UNDER THE FILTER RULE

A11 Transactions With Expected $X$ and $Y$ of $\$ 100$ or More

\begin{tabular}{|c|c|c|c|c|c|c|}
\hline Description & $\begin{array}{l}\text { No of } \\
\text { Transac- } \\
\text { tions }\end{array}$ & $\begin{array}{l}\text { Total } \\
\text { Invest- } \\
\text { ment } *\end{array}$ & $\begin{array}{l}\text { Potal } \\
\text { Profit }\end{array}$ & $\begin{array}{l}\text { Avg. } \\
\text { No. of } \\
\text { Months }\end{array}$ & $\begin{array}{l}\text { Annual } \\
\text { Yield }\end{array}$ & $\begin{array}{c}\text { Predict } \\
\text { ed } \\
\text { Profit }\end{array}$ \\
\hline $\begin{array}{l}\text { American Dist. } \\
\text { Collins Radio } \\
\text { Comb. Engineer. } \\
\text { Cont. Baking } \\
\text { Cop. Steel } \\
\text { Dresser Indus. } \\
\text { Food Fair } \\
\text { Gen. Amer. Oil } \\
\text { Int Tel. \& Tel. } \\
\text { Northrop } \\
\text { Olin. Math. } \\
\text { Dhilizps Pet. } \\
\text { Rohr } \\
\text { Scott Paper }\end{array}$ & $\begin{array}{r}2 \\
2 \\
3 \\
2 \\
2 \\
1 \\
2 \\
2 \\
2 \\
6 \\
3 \\
5 \\
12 \\
2\end{array}$ & $\begin{array}{l}\$ 2115 \\
2852 \\
4083 \\
2280 \\
2309 \\
1146 \\
2178 \\
2101 \\
3225 \\
9755 \\
3651 \\
6432 \\
17816 \\
2457\end{array}$ & $\begin{array}{r}73 \\
-\$ 17 \\
352 \\
92 \\
48 \\
12 \\
123 \\
93 \\
734 \\
619 \\
182 \\
119 \\
2738 \\
132\end{array}$ & $\begin{array}{r}24.0 \\
7.5 \\
13.2 \\
24.0 \\
17.0 \\
23.0 \\
24.0 \\
16.5 \\
12.5 \\
18.5 \\
23.1 \\
24.0 \\
16.1 \\
28.5\end{array}$ & $\begin{array}{c}-1.73 \% \\
9.68 \\
5.88 \\
2.01 \\
1.46 \\
.54 \\
-2.82 \\
3.21 \\
21.84 \\
4.11 \\
2.59 \\
. .92 \\
11.45 \\
2.25\end{array}$ & $\begin{array}{r}\$ 269 \\
329 \\
341 \\
291 \\
264 \\
107 \\
248 \\
333 \\
340 \\
825 \\
527 \\
881 \\
1905 \\
243\end{array}$ \\
\hline Total & 46 & $\$ 62400$ & $\$ 5098$ & 18.9 & $5.19 \%$ & $\$ 6903$ \\
\hline
\end{tabular}

*Based on purchasing one bond per transaction, and assuming $70 \%$ margin requirement on accompanying short sale. 
Looking at this array of yield figures produced by eliminating the one exceptional transaction,

Nonselective (133 transactions): 2.82 per cent $\$ 100$ or more (45 transactions): 4.22 per cent $\$ 150$ or more (19 transactions): 5.02 per cent $\$ 175$ or more (13 transactions): 4.76 per cent the 1.40 percentage-point spread between 2.82 and 4.22 per cent is both statistically and financially significant. 9 The smaller spread of 0.80 percentage points between the 4.22 and 5.02 per cent yields, while statistically significant, represents only a very moderate financial improvement. 10 The 4.76 per cent yield, of course, casts considerable suspicion on the ability of the $X$ and $Y$ equations to sort out transactions on a more refined basis. It is debatable whether the one exceptional transaction should be included or excluded. In order to preserve the option of including it, the decision was made to adopt the $\$ 100-0 r-m o r e ~ s e l e c t i o n$ rule as a conservative basis for further analysis.

In regard to the second approach, there are two rational ways to employ greater margin leverage in the partial hedge.

9 The arithmetic mean of the yields of the $\$ 100$-or-more sample departs from the mean of the nonselective sample by 2.470 standard errors, and at a 5 per cent level of statistical significance, any departure greater than .005 standard errors is significant.

Towhe arithmetic mean of the yields of the \$50-or-more sample departs from the mean of the $\$ 100$-or-more sample by 0.077 standard errors, and at a 5 per cent level of statistical significance, any departure greater than .008 standard errors is significant. 
One way, which is beyond the control of the partial hedger, is for the Federal Reserve to lower the margin requirement on short sales to some level below the 70 per cent assumed in the analysis. The other way is to take advantage of a technical provision in the Federal Reserve's Regulation $T$ covering margin requirements on so-called "special accounts." The partial hedge meets the requirements of Section 220.4, part (d) of Regulation T pertaining to "arbitrage accounts," one of several types of "special accounts" described in the regulation. An account is classified as an "arbitrage account" if it is used for

- purchase of a security which is, with-
out restriction other than the payment of
money, exchangeable or convertible within 90
calendar days following the date of its pur-
chase into a second security together with an
offsetting sale at or about the same time of
such second security. . . ll

No margin requirement is imposed by the Federal Reserve on such an "arbitrage account," up to the limits imposed by the relative price levels of the two securities and the conversion terms. For example, if a bond were convertible into 20 shares and the shares were currently selling for $\$ 50$ while the bond sells for $\$ 1000$, the partial hedger could purchase the convertible on whatever margin a broker or banker is willing to agree to, and short up to 20 shares of the common, again on by Brokers, Dealers, and Nembers of National Securities Exchanges, Regulation I, As Amended Erfective March 11, 1968, p. 12. 
whatever terms the lender is. willing to agree to. There is, however, a practical limitation. As pointed out by S. T. Kassouf, a broker is not likely to advance more than 50 per cent or so on the bonds in combination with zero margin on the short sale; a bank would probably loan more than 50 per cent on the bonds alone, but would insist on holding the bonds as collateral, destroying the "arbitrage" clssification as far as the account at the broker's office is concerned, and thus requiring margin on the short sale.12

Another possible method' of arranging greater margin leverage lies in the use of the convertible as margin on the short sale in lieu of cash, but under the regular rather than the special provisions of Regulation $T$. In the partial hedge tests, the 70 per cent margin requirement assumed for short sales called for collateral averaging 26.5 per cent of current bond value. If 30 per cent is taken as maximum loan value on the convertibles, the bonds would more than cover the margin requirement.

In regard to the third basic method of improving the yields, one source of loss during the 1956-66 period of the study was the erosion of intrinsic values. During this period, Moody's average yield on A-grade bonds rose from 3.19 to nearly 6 per cent. The decline in intrinsic values, however, affected only the approximately forty per cent of the

$12 \mathrm{~S} . \mathrm{T}$. Kassouf, Evaluation of Convertible Securities, (New York, 1962), Appenáix C, p. 37 . 
transactions in which stock prices declined. Had no decline in intrinsic values occurred, the yield would have increased by approximately one percentage point. Although a forecast. of future interest rates is beyond the limits of this study, it is probably true that the pattern of interest rate movements over the 1956-66 period was not a "normal" pattern in the sense that one would predict its repetition over the next ten years, or any ten year segment chosen at random from past history. One would expect to find periods of decline and periods of relative stability in such a sampling, as well as periods of rise. The expected rate of return on the partial hedge could be increased over the rates produced by the study if the hedger either operated in a period of stable or declining interest rates as a matter of fortunate coincidence, or restricted his hedging comitments to such periods on the basis of some technique for forecasting interest rates.

Table XXIII shows not only the partial hedge yields discussed earlier, but summarizes also the yields resulting from use of the three methods, just discussed, for improving the yields. With $X$ or $Y$ of $\$ 100$ or more, with the one exceptionaliy profitable transaction excluded, but with stable intrinsic values assumed, the 5.17 per cent yield under the original 70 per cent margin requirement on short sales increases to 5.50 per cent with a 50 per cent margin requirement, 6.07 per cent with a 20 per cent margin requirement, 6.52 
TABLE XXIII

SUMMARY OF RATES OF RETURN ON THE

PARTIAL HEDGEi:

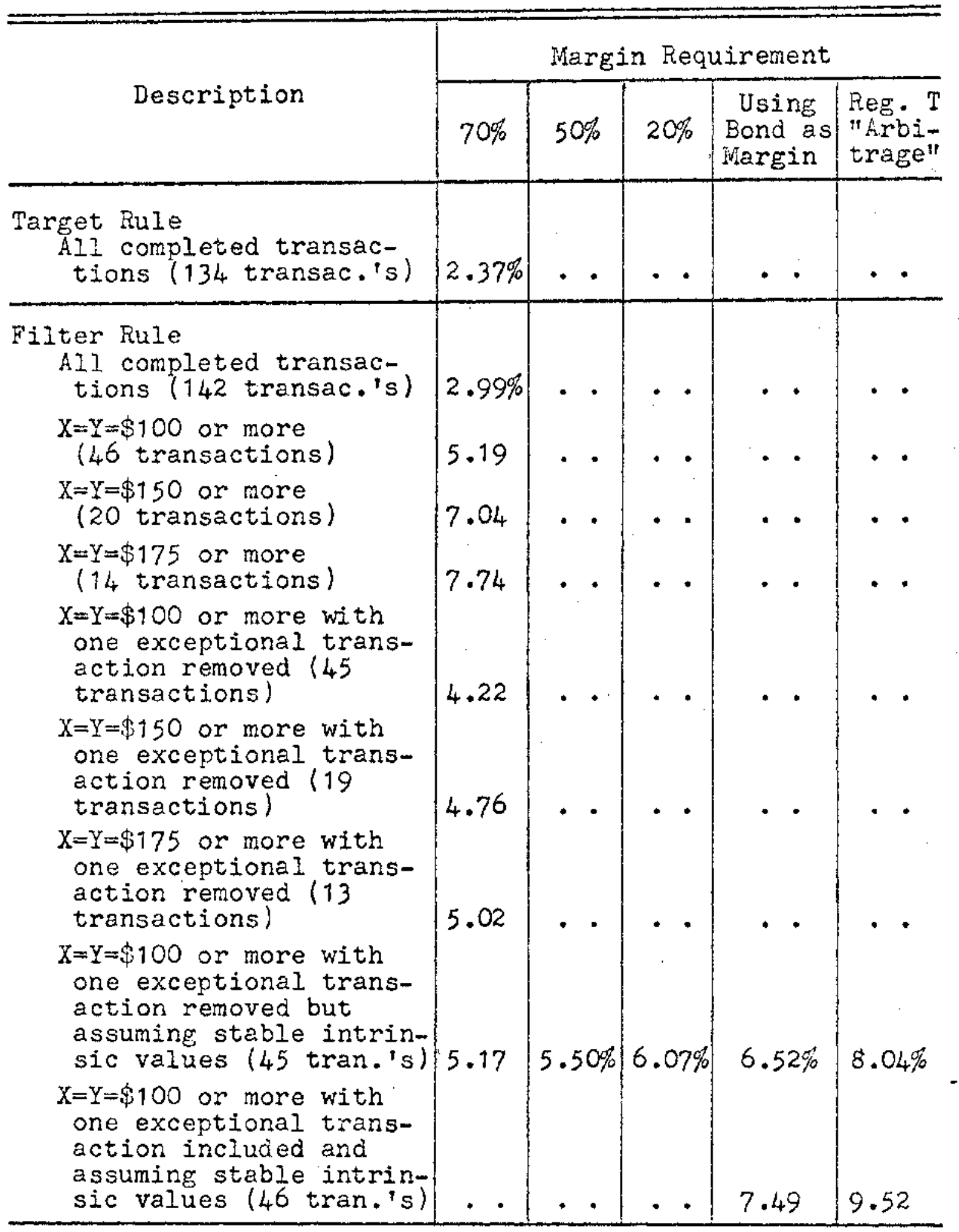


per cent with the bond used as margin, and 8.04 per cent under the technical "arbitrage" provisions of Regulation $T$. If the one exceptionally profitable transaction is included, the last two of these yields increase to 7.49 and 9.52 per cent, respectively.

These rates were computed without regard to taxes, commissions, interest received, or dividends paid on stock sold short. As it happens, however, commissions, interest received, and dividends paid almost exactly cancel one another out, depending upon the assumptions made about transaction size and corresponding brokerage commission. Among the transactions with originally expected $X$ and $Y$ of $\$ 100$ or more, the bond interest received, expressed as a ratio of coupon interest to the combined original market values of bonds and stocks, averaged 3.1 per cent (this manner of expression placed the interest percentage on a basis comparable to the commission charge). On the same basis, dividends paid on the short sales averaged 1.0 per cent. The 2.1 per cent difference would act as an offset to total in-andout commission charges of up to 2.1 per cent of the transaction value, a reasonable allowance for all but very small investors. Computation of the yields on a before-tax basis was consistent with the policy followed in previous chapters. It can be noted, however, that since the stock involved in the partial hedge transactions rose about sixty per cent of the time, short sale losses exceeded short sale gains, 
eliminating this potential source of short-term capital gains taxes. Furthermore, only one of the $\$ 100$-or-more transactions completed under the filter rule was terminated in less than six months (the average was 18.9 months). Tax rates should, therefore, compare favorably with other investment techniques-more favorably than the rates applicable to the primary market transactions.

Conclusion

The partial hedge is basically a highly conservative technique that would appeal to a very risk-conscious investor. It should not be expected, therefore, to yield large overall profits relative to other techniques. With certain refinements in the technique, annual returns ranging from 5.17 to 9.52 per cent (before taxes) were obtained in the study, depending upon the margin arrangement used and on whether one unusually profitable transaction is included or excluded. The greater the margin leverage, of course, the more the hedger sacrifices the goal of minimizing risk. Comparing this range of rates with the average of about 5 per cent on straight bonds, 6.38 per cent on listed convertibles in a direct buy-and-hold strategy, and 8.42 per cent for direct buy-and-hold commitments in convertible-matching stocks (the latter two rates are shown in Table XV), the partial hedge appears to be a rational technique, but one that operates in a market environment lacking sufficient imperfections to generate above-average rates of return. 
CHAPTER VI

\section{THE FULL HEDGE}

The full hedge is superficially similar to the partial hedge investigated in the previous chapter, but it is conceptually distinct. The perfect partial hedge, it will be recalled, involved seling short half the number of common shares into which the bond is convertible, with a "halfsized" profit resulting from either a rise or decline in the price of the common stock. In the ideal full hedge, the hedger sells short the full number of shares into which the bond is convertible. This assures, in the ideal case, a full profit if the stock price falls and a break-even result if the stock price rises.

Suppose, for example, that the bond is selling at $\$ 1000$, that it is convertible into ten shares of common stock, and that the stock is currently selling at $\$ 100$ per share. The hedger would buy the bond and sell short ten shares of the common stock. If the stock subsequently rises to, say, $\$ 150$ per share the hedger will lose $\$ 500$ on the short sale but will make $\$ 500$ on the bond, netting a zero profit. If, on the other hand, the market price of the common stock declines to, say, $\$ 50$ per share the hedger will earn $\$ 500$ on the short sale but will lose nothing on the bond because it will continue 
to sell at $\$ 1000$ on the basis of its merits as a bond-that is, an instrument paying a set rate of interest and refunding principal at maturity.

While the partial hedger is indifferent to the directional movement of the common stock, the full hedger. would clearly prefer a downward change in the stock price. Herein lies the basic distinction between the partial hedge and the full hedge. Both techniques share the common advantage, however, of avoiding the usual investment requirement that an opinion be formed about the probable directional movement of the stock price and that a commitment be made on the basis of that opinion.

The full hedger is not precluded from forming such an opinion, nor from being selective in the commitments made, in an attempt to engage in a greater number of transactions involving downside profit and fewer involving the upside breakeven result. But whether such a strategy will be useful hinges on whether short-term market movements are predictable. This question is the subject of great controversy among researchers, and a full examination of the issue cannot be undertaken here. Readers are referred to the works of Eugene F. Fama ${ }^{1}$ and Lawrence Fisher ${ }^{2}$ for arguments and data in

1 Eugene F. Fama, "Random Walks in Stock Market Prices," Sinancial Analysts Journal, XXI (Sept.-Oct., 1965), 55-59; and "The Behavior of Stock-Market Prices," Journal of Business, University of Chicago, XXXVIII (Jan., 1965), $\frac{01}{34}-105$

2Lawrence Pisher, "Outcomes for lkandom' Investments in Common Stocks Listed on the New York Stock Exchange," The

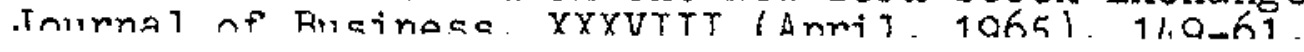


support of the thesis that stock price movements are random, and to the articles of such researchers as Leo Barnes 3 and Paul H. Cootner for rebuttals. The general assumption adopted in the present study is that short-term stock market movements are, if not random, at least so difficult to predict that the full hedger is justified in following a nonselective strategy as far as anticipated directional movement is concerned (unfortunately, predictions must still be made on the magnitude of such movements). The possible exception is an adjustment of" some sort to take into account an assumed continuation of the long-run upward bias in the stock market--a bias admitted even by the most enthusiastic advocates of randomness in short-run market movements. This possibility will be expored later in the chapter, after more adequate tools have been developed to extend the analysis.

The underlying objective of the full hedger is, of course, to realize a satisfactory profit on his investments. For analytical purposes, however, the immediate objective at each investment decision point will be assumed to be a breakeven profit anytime the price of the common stock rises after engaging in each hedging operation. It is on this basis that the equations in the following section were developed.

3Leo Barnes, "What Difference Does Knowledge Make?," Financial Analysts Journal, XXI (Sept.-Oct., 1965), 60-68.

4paul H. Cootner, "Stock Prices: Randon vs. Systematic Changes," Industrial Management Review, III (Spring, 1962), $24-45$. 
This approach does not, however, mean that the full hedger must passively accept any and all downside profits even if they are small or negative; the hedger can determine the size of expected downside profits and engage only in transactions with an expected return greater than some specified minimum, as was done in the partial hedge.

The potential effectiveness of the full hedge is diminished by the same sort of problems that pervade the partial hedge: Conversion values above intrinsic values with corresponding chance of loss through decline in conversion value; speculative premiums that may shrink; and possible declines in intrinsic value due to increases in generally prevailing interest rates or an adverse change in credit rating of the company. The challenge, as before, is to develop decision models sophisticated enough to skirt around these problems so as to produce above-average return on the full hedge technique. As was the case in the partial hedge, the most pressing need is for decision models to specify the exact number of common shares to sell short in each hedging transaction, and to decide whether to engage in the transaction at all.

\section{Developing the Equations}

The same symbols used in the partial hedge equations can be used in formulating decision models for the full hedge, except for a redefinition of the symbol $X$. The symbols are repeated here for convenience: 


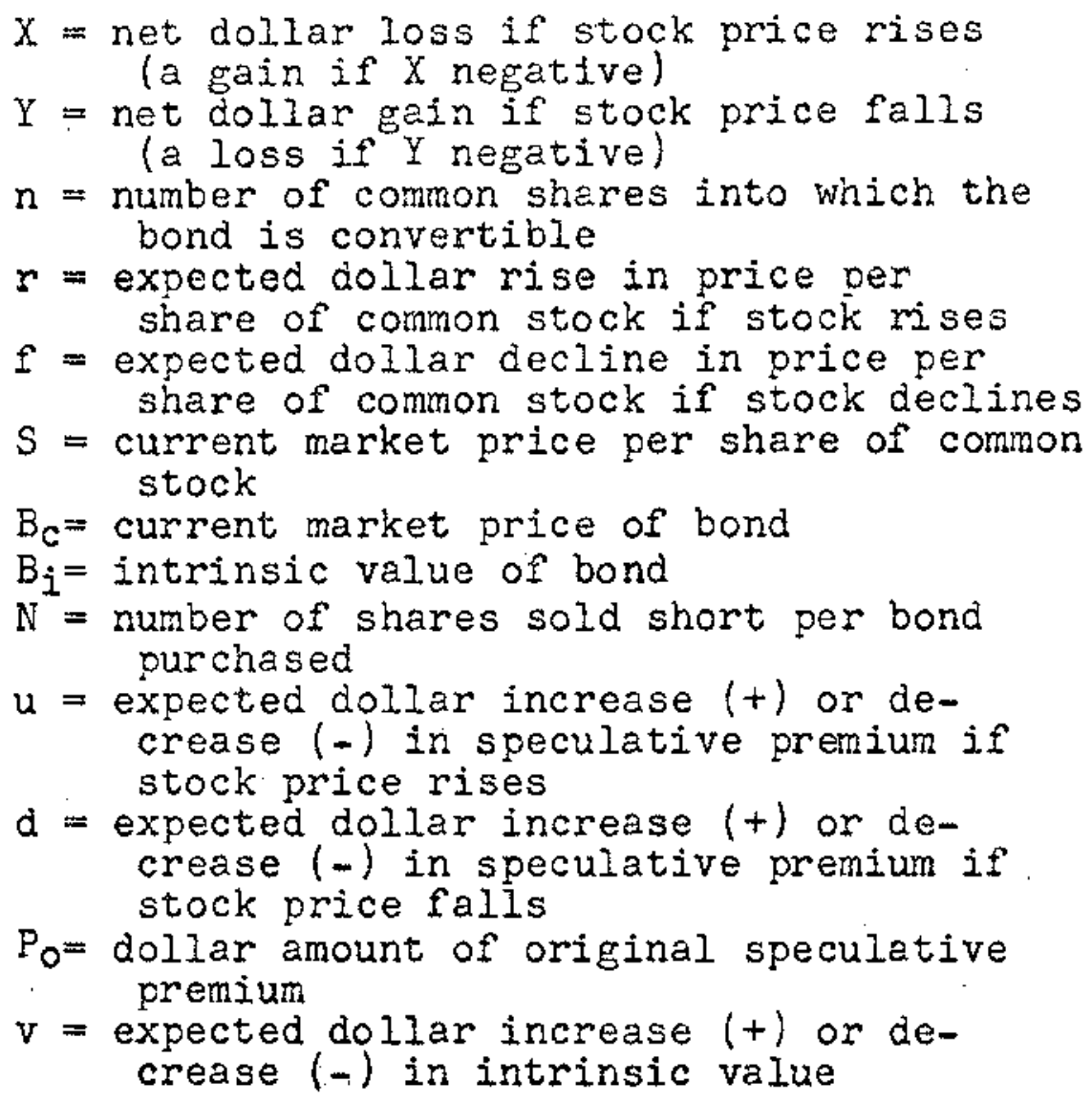

As in the partial hedge, the prospective full hedge situations fall into two major categories: Either the current, conversion value of the bond is at or below intrinsic value, or current conversion value is above current intrinsic value.

\section{Current Conversion Value at or Below} Current Intrinsic value

The three subsets identified in the partial hedge are useful starting points for development of the full hedge equations also:

Conversion value too far below intrinsic value..- When the conversion value is so far below intrinsic value that the anticipated rise in stock price, $r$, will be insufficient 
to overcome the deficit, a loss will result if the stock price does rise. No hedge is possible. The bond will remain at intrinsic value (subject to change in the intrinsic value itself or in the speculative premium), and a direct loss will result on the short sale.

While one may, of course, try to profit directly from changes, $v$, in the intrinsic value of the bond, the proper attitude for present purposes is to regard $v$ as something to be guarded against, not profited from.

Banking on the appearance of a speculative premium-that is, on a positive u--to drive the bond price above intrinsic value is technically rational inasmuch as such premiums were seen in the previous chapter to be functionaliy related to relative movements in the price of the common stock. But to be conservative, to add a margin of safety, this possibility can be ruled out and the following policy statement formulated:

\section{Policy Statement H}

$$
\begin{aligned}
& \text { If } \frac{B_{i}}{n}-S>r \\
& \text { Do Not Engage }
\end{aligned}
$$

This is the same as Policy Statement A, except that the expression in Policy Statement $A$ has been "turned around" to stress the fact that the problem lies not in a small $r$ (from the fuli hedger's point of view, the smaller the $r$, the better), but in the fact that the original price of the common stock is too far below the conversion breakeven price. 
New conversion value expected to exceed new intrinsic value if stock price rises.--This situation, which is a basically desirable one, exists when $v$ is negative or when $n(r+s)-B_{i}>v$ if $v$ is positive. In this case, the before-tax and before-commission profit, $Y$, resulting from a decline in the stock price is given by:

Equation 9

$$
Y=N f+v+d
$$

This is exactly the same as Equation 2 on page 190.

The loss generated by a rise in the price of the common stock is denoted by:

$$
\text { Equation } 10 \quad \mathrm{X}=\mathrm{Nr}+\mathrm{B}_{\mathrm{i}}-\mathrm{n}(r+\mathrm{S})-\mathrm{u}
$$

In the $X$ equation, $v$ is irrelevant.

To determine the number of shares, $N$, to sell short per bond purchased, $X$ in Equation 10 is set equal to zero and the right side solved for $N$, resulting in:

$$
\text { Equation } 11 \quad N=\frac{n(r+S)-B_{i}+u}{r}
$$

This procedure will produce an expected loss of zero if the common stock rises in price. It does not, however, specify that the expected profit on the downside is large enough to justify the investment, or even positive at all. Hence, the $N$ produced by Equation 11 should be fed into the $Y$ equation (Equation 9) to check the sign and magnitude of this expected profit. 
Just as the perfect partial hedge can be described algebraically, so can the perfect full hedge situation. It exists when Equation 11 is applicable and when:

$$
\begin{aligned}
& r=f=c \\
& u=0 \\
& d=0 \\
& v=0 \\
& B_{i}=n S \quad \begin{array}{l}
\text { (that is, where the current price of } \\
\text { the boind }=\text { intrinsic value = conversion } \\
\text { value) }
\end{array}
\end{aligned}
$$

So that, from Equation 11:

$$
N=\frac{n(c+s)-B_{i}}{c}
$$

Or, substituting $\mathrm{nS}$ for $\mathrm{B}_{i}$ and simplifying:

$$
\text { Equation } 12 \quad \mathrm{~N}=\mathrm{n}
$$

That is, in the perfect full hedge, the hedger sells short, per bond purchased, the same number of common shares as the bond could be converted to. In such a situation, the expected profit, $Y$, if the stock price declines is equal to Nc. The expected loss, $X$, if the stock price rises is, as in every full hedge situation, zero.

New intrinsic value expected to exceed new conversion value if stock price rises.--This condition exists when $n(r+s)-B_{i}<v$, with a positive $v$. The $Y$ equation in this situation would remain the same as in the previous situation:

$$
Y=N f+v+d
$$


The $X$ equation changes to:

$$
\mathrm{X}=\mathrm{v}-\mathrm{Nr}+\mathrm{u}
$$

in which the new conversion value is irrelevant.

Setting $X=0$ and solving for $N$ :

$$
N=\frac{u+v}{r}
$$

Similarly to the circumstances described on pages 196 and 197, this puts the hedger in the position of speculating on $u$ and $v$. As stated previously, $v$ should be viewed as a variable to be guarded against in a hedging operation, not as something to be profited from. And commensurate with the hedger's conservative nature, a strong case can be made for disregarding a change in speculative premium as a potential source of profit in this situation. Hence, $N$ should be read as zero in the above equation and the transaction should be avoided. That is:

Folicy Statement I $\quad \begin{gathered}\text { If } \mathrm{v} \text { is positive and } \\ \mathrm{n}(\mathrm{r}+\mathrm{S})-\mathrm{B}_{\mathrm{i}}<\mathrm{v} \\ \text { Do Not Engage }\end{gathered}$

This is identical to Policy Statement $E$ in the partial hedge.

\section{Current Conversion Value Above Current Intrinsic Value}

As mentioned in the previous chapter, convertibles often sell above their intrinsic values because the common stock has risen above the conversion breakeven point (plus the fact that speculative premiums are usualiy present). Convertibles 
are typically issued at a conversion price not far above the then-prevailing price of the common stock so that a moderate rise in the common creates a bond conversion value in excess of intrinsic value.

Three subsets can again be identified:

Bond not expected to decline to intrinsic value if stock price falls... That is, $f<\frac{B_{C}-B_{i}-P_{0}}{n}$. As in the similar case described in the partial hedge, there will be no "floor" to cushion loss on the bond. The gain on the short sale will be offset except for incidental increases in intrinsic value, $v$, or increases in speculative premium, $d$, both of which should, as before, be regarded as inadecuate justification for engaging in the transaction. Thus:

$$
\text { Policy Statement } K \quad \begin{gathered}
\text { If } f<\frac{B_{c}-B_{i}-P_{0}}{n} \\
\text { Do Not Engage }
\end{gathered}
$$

New conversion value expected to exceed new intrinsic value if stock price rises.-..This situation, a basically desirable one, exists when $v$ is negative or $n(r+s)-B_{i}>v$ when $\mathrm{v}$ is positive. In this case, the $\mathrm{Y}$ equation becomes:

$$
\text { Equation } 13 \quad Y=N f-n S+B_{i}+v+d
$$

And the $\mathrm{X}$ equation becomes:

$$
\text { Equation } 14 \quad X=N r+B_{c}-n(r+S)-u-P_{0}
$$

Setting $X=0$ and solving for $N$ results in: 


$$
\text { Equation } 15 \quad N=\frac{n(r+S)-B_{C}+u+P_{O}}{r}
$$

New intrinsic value expected to exceed new conversion value if stock price rises.--As in the similar situations described previously, this is a fundamentally undesirable hedging situation. The policy statement applied previousiy can be repeated here:

Policy Statement $\mathrm{L} \quad \begin{gathered}\text { If } \mathrm{v} \text { is positive and } \\ \mathrm{n}(\mathrm{r}+\mathrm{s})-\mathrm{B}_{i}<\mathrm{v} \\ \text { Do Not Engage }\end{gathered}$

Summary of Equations

The following is a step-by-step summary of the procedure to follow in applying the full hedge equations.

First, the current intrinsic value of the bond and the current conversion value must be determined. If the conversion value is at or below intrinsic value, the steps under A below should be followed; if above intrinsic value, the steps under $B$ should be followed. After applying any $N$ equation, $Y$ should be computed to check for negative or small expected profits. If $\mathrm{N}$ is zero or negative, the hedger should not engage in the transaction.

A. Current Conversion Value at or Below Current Intrinsic 1. Predict $r$ and $f$. If $f=0$, do not engage and proceed no further. 
2. If $\frac{B_{i}}{n}-S>r$, do not engage and proceed no further.

3. If $\mathrm{v}$ is positive and $\mathrm{n}(\mathrm{r}+\mathrm{s})-\mathrm{B}_{\mathrm{i}}<\mathrm{v}$, do not engage and proceed no further.

4. If $v$ is negative or if $n(r+S)-B_{i}>v$ when $v$ is positive, apply one of the following $\mathbb{N}$ equations, feeding any positive $\mathbb{N}$ into the $Y$ equation shown:

$$
\begin{aligned}
& \text { (a) If } r=f=c ; P_{0}=0 ; u=0 ; d=0 ; \\
& v=0 ; \text { and } B_{i}=n S: \\
& N=n \\
& Y=N c \\
& \text { (b) If the conditions in (a) are not satis- }
\end{aligned}
$$
fied:

$$
\begin{aligned}
& N=\frac{n(r+S)-B_{i}+u}{r} \\
& Y=N f+v+d
\end{aligned}
$$

B. Current Conversion Value Above Current Intrinsic Value

1. Predict $r$ and $f$. If $f=0$, do not engage and proceed no further.

2. If $f<\frac{B_{c}-B_{i}-P_{0}}{n}$, do not engage and proceed no further.

3. If $v$ is positive and $n(r+s)<v$, do not engage and proceed no further.

4. If $v$ is negative or $n(r+S)-B_{i}>v$ when $v$ is positive: 


$$
\begin{aligned}
& N=\frac{n(r+S)-B_{C}+u+P_{0}}{r} \\
& Y=N f-n S+B_{i}+v+d
\end{aligned}
$$

As a matter of general policy, of course, transactions in which $N$ or $Y$ is less than or equal to zero should be avoided by the full hedger.

Should an Adjustment be Made for Upward Bias in the Stock Market?

It is a virtual truism that the stock market manifests an upward bias in the secular movement of prices, at least insofar as historical price movements are concerned. A case could also be made for assuming that the long-run uptrend in the market will continue into the future; and that any shortterm price forecasts should take into account the greater general probability of a price rise than of a price decline. In the convertible bond hedging models just developed, it is the probability of occurrence of $r$ and $f$, respectively, that is called into question. If, for example, the probability of decline is .4 , should not the full hedger make a downward adjustment in the number of shares sold short, $N$ ? This approach was ruled out for the partial hedge, but can it also be ruled out for the full hedge?

If probability weighting is to be introduced into the full hedge, it would logically be on the basis of maximizing the expected (probability-weighted) sum of $X$ and $Y$. Using, for example, Equations 9 and 10, this approach can be applied 
by first multiplying the $X$ equation through by $(-1)$ to express $X$ as a profit rather than as a loss. Letting $\Sigma$ represent the sum of the probability-weighted expected profits, $k$ the probability of a rise in the price of the common stock, and $(1-k)$ the probability of decline:

$$
\Sigma=(k)\left[n(r+s)-B_{j}-N r+u\right]+(1-k)(N f+v+d)
$$

Rearranging:

$$
\sum=N(f-k r-k f)+k\left[n(r+s)-B_{i}+u-v-\bar{d}\right]+v+d
$$

At the point of decision regarding $N$, the parameters $f$, $k, n, S, B_{i}, u, d$, and $v$ are all regarded as constants. This makes $\sum$ a linear function with slope of $(f-k r-k f)$. The slope can be positive, negative, or zero, depending upon the magnitudes of $k, r$, and $f$. Specifically:

$\begin{array}{ll}\frac{I f}{k=\frac{f}{r+f}} & \text { Slope Is } \\ k>\frac{f}{r+f} & \text { Zero } \\ k<\frac{f}{r+f} & \text { Positive }\end{array}$

If the slope is zero, total probability-weighted expected profit is constant regardiess of the size of $\mathrm{N}$. If the slope is negative, total probability-weighted expected loss is minimized when $N=0$.

If slope is positive, total probability-weighted expected profit is maximized when $N=\infty$. 
In the case in which $r=f$, as a clarifying example, this means simply that with any probability of stock price decline of .5 or more, an infinite number of common shares (mathematically speaking) should be sold short; while if the probability of decline is less than .5, no common shares should be sold short.

Hence, this approach results in an inappropriate decision model for the full hedge. An investor who uses this proba. bility model would be attempting to maximize total probabilityweighted expected profit, facing the uncertainty of whether the probability assignmerts are correct, and the fact that they are applicable only to a long series of transactions and not to individual transactions. Such an investor would (except in the rare case of a zero slope) either make a straight bond purchase or sell as many common shares short as available funds permit, up to an infinite number. In the latter case, a little additional reasoning will reveal that the bond should not be purchased at all, since it would only increase the investment and thus decrease the percentage return on investment. Such an investor would not, in short, combine a short sale with a bond purchase and thus, by definition, cannot be a full hedger.

In contrast to such an indiviaual, the fuIl hedger attempts to eliminate much of the uncertainty regarding individual transactions--that is, attempts (though not with perfect results) to narrow the range of possible outcomes down 
to two clear-cut possibilities, either a $z$ ero profit if the stock price rises or a full profit if the stock declines-accepting as a major source of uncertainty the number of transactions that will fall in each category and hence the total profit on a series of transactions relative to the total investment required.

The purpose of the following applications section is to help reduce this special type of uncertainty faced by the full hedger, and to measure the rate of return one might reasonably expect to realize from use of the technique.

\section{Applying the Equations}

The basic procedure for applying the full hedge equations was similar to that employed in the partial hedge. The appropriate $\mathbb{N}$ equations were exposed to historical price data on convertibles and convertible-matching stocks, hypothetically engaging in all transactions in which a positive profit of any size was indicated by the $Y$ equations. The data was further processed on the basis of selected transactions on which originally expected profit exceeded specified minimums. Rates of return, expressed as annual yields, were computed to measure the profitability of the full hedge technique and to try to shed further light on the degree of perfection in the secondary convertible bond market.

like the partial hedge, the full hedge is sensitive to erosion of intrinsic values of convertibles. Hence, as in 
the partial hedge, only the top-rated convertibles were included in the sample of historical data. The monthly data collected for the partial hedge was in every way suitable for the full hedge, except that it was updated through April, 1968 (covering, then, the period from January, 1956, through April, 1968). This involved, in all, some 6200 bits of raw price data.

Intrinsic values $\left(B_{i}\right)$, original speculative premiums $\left(P_{0}\right)$, expected changes in speculative premiums (u and $d$ ) were computed as described in the previous chapter. And it was again assumed that the expected change in intrinsic value (v) equaled zero in all applications. The timing rule described on page 202 was also used again. And, as before, all initial computations and tabulations were on a beforetax and before-comission basis.

Since the full hedger is not indifferent to the directional movement of the stock price, the terminating rules had to be modified, although two separate rules were again employed and the results of each compared in the applications test. The revised "target rule" specified that if the stock price increased as much as fifty per cent of $r$ (the expected price rise), the transaction would be teminated (on the basis that the directional movement of the stock is unfavorable and the invested funds, while not expected to accumulate losses as such, could be more profitably invested in another transaction); if, on the other hand, the stock price declined, 
the transaction would be terminated when the expected price change, $f$, was reached, with a limit of twenty-four months.

The modified "filter rule" called for keeping the domside transactions open beyond the target price level until each successive low had reversed itself by as much as ten per cent, with a limit of twenty-four months if the target price was not reached.

\section{Results of the Application}

The initial results of the test using the modified target mule are summarized in Table XXIV, which includes some 186 transactions completed under this rule $(12$ transactions were still pending when the data expired). Table XXV shows the transactions completed under the modified filter rule; compared with the modified target rule, there were no differences in the number of transactions engaged, terminated, and pending. These two tables include all completed transactions with original expected $Y$ 's greater than zero, even if quite small. Total investment was computed on the assumption of a seventy per cent short sale margin with stocks "loaning flat," and assuming that the hedger purchases one $\$ 1000$-denomination bond per transaction.

The target rule produced an overail annual yield of: only 0.63 per cent. The filter rule, in contract to its performance in the partial hedge, resulted in an even lower 0.30 per cent. The basic reason for the generally low yield 
TABLE XXIV

ALL FULI HEDGE TRANSACTIONS COMPLETED UNDER THE TARGET RULE

\begin{tabular}{|c|c|c|c|c|c|}
\hline Description & $\begin{array}{l}\text { No. of } \\
\text { Transac- } \\
\text { tions }\end{array}$ & $\begin{array}{l}\text { Total } \\
\text { Invest- } \\
\text { ment }\end{array}$ & $\begin{array}{c}\text { Total } \\
\text { Profit }\end{array}$ & $\begin{array}{l}\text { Avg. } \\
\text { No. of } \\
\text { Months }\end{array}$ & $\begin{array}{l}\text { Annual } \\
\text { Yield }\end{array}$ \\
\hline $\begin{array}{l}\text { Air Reduction } \\
\text { American Distilling } \\
\text { Amer. Nachine \& F. } \\
\text { Armour } \\
\text { Ashland Oil } \\
\text { Aurora Plastics } \\
\text { Avco } \\
\text { Beaunit } \\
\text { Celanese } \\
\text { Collins Radio } \\
\text { Comb. Engineering } \\
\text { Continental Baking } \\
\text { Coperw. Steel } \\
\text { Crowell Collier } \\
\text { Dow Chemical } \\
\text { Dresser } \\
\text { Food Fir } \\
\text { Gen. American Oil } \\
\text { General Instr. } \\
\text { General Time } \\
\text { Grace (W. R.) } \\
\text { Granite City Steel } \\
\text { Hunt Foods } \\
\text { Int. T \& T } \\
\text { Litton } \\
\text { Macy } \\
\text { Northrop } \\
\text { Olin. Math. } \\
\text { Oxford Paper } \\
\text { Phil. Petroleum } \\
\text { Rohr } \\
\text { Scott Paper } \\
\text { Sinclair } \\
\text { Stevens, J. P. } \\
\text { United Aircraft }\end{array}$ & $\begin{array}{c}6 \\
8 \\
\text { None } \\
3 \\
3 \\
4 \\
5 \\
2 \\
1 \\
6 \\
15 \\
11 \\
12 \\
2 \\
3 \\
5 \\
10 \\
14 \\
1 \\
3 \\
\text { None } \\
5 \\
\text { None } \\
2 \\
\text { None } \\
2 \\
11 \\
10 \\
2 \\
12 \\
12 \\
7 \\
4 \\
2 \\
3 \\
10 \\
12 \\
1 \\
10\end{array}$ & $\begin{array}{r}8684 \\
11229 \\
\cdot \\
3745 \\
5332 \\
5491 \\
9855 \\
2138 \\
1034 \\
9426 \\
23332 \\
16320 \\
18400 \\
3125 \\
1881 \\
7753 \\
13366 \\
19942 \\
1583 \\
3926 \\
\cdot \\
6778 \\
\cdot \\
3766 \\
28 \\
2680 \\
20907 \\
16057 \\
2849 \\
21800 \\
20809 \\
11340 \\
5976 \\
3485 \\
4943\end{array}$ & $\begin{array}{r}\$ 120 \\
-312 \\
221 \\
-77 \\
188 \\
78 \\
-38 \\
27 \\
109 \\
316 \\
-171 \\
57 \\
85 \\
73 \\
411 \\
-35 \\
162 \\
94 \\
-\quad 1 \\
0.210 \\
-2 \\
97 \\
-\quad \\
-16 \\
169 \\
185 \\
18 \\
-267 \\
24 \\
-27 \\
234 \\
108 \\
31\end{array}$ & $\begin{array}{l}17.3 \\
19.4 \\
.0 .3 \\
9.3 \\
5.0 \\
11.2 \\
9.0 \\
2.0 \\
2.0 \\
6.7 \\
9.2 \\
10.4 \\
9.0 \\
5.7 \\
7.0 \\
19.5 \\
16.0 \\
1.0 \\
11.3 \\
18.0 \\
18.0 \\
3.0 \\
14.0 \\
8.3 \\
12.7 \\
11.0 \\
14.3 \\
10.2 \\
11.3 \\
14.0 \\
5.0 \\
8.0\end{array}$ & $\begin{array}{r}.96 \% \\
-1.71 \\
7.61 \\
-3.46 \\
8.21 \\
.85 \\
-2.36 \\
15.66 \\
6.90 \\
2.42 \\
-1.36 \\
.35 \\
3.63 \\
8.17 \\
9.09 \\
-.16 \\
.56 \\
71.16 \\
0.00 \\
.0 .06 \\
-2.06 \\
10.28 \\
0.00 \\
1.16 \\
1.09 \\
.69 \\
-1.02 \\
.13 \\
.24 \\
3.35 \\
7.42 \\
.93\end{array}$ \\
\hline Total & 186 & $\$ 287952$ & $\$ 1668$ & 11.0 & $.63 \%$ \\
\hline
\end{tabular}

*Based on purchasing one bond per transaction, and assuming $70 \%$ margin requirement on accompanying short sale. 


\section{TABLE XXV}

ALL FULI HEDGE TRANSACTIONS COMPLETED UNDER THE FILTER RULE

\begin{tabular}{|c|c|c|c|c|c|}
\hline Description & $\begin{array}{l}\text { No. of } \\
\text { Transac- } \\
\text { tions }\end{array}$ & $\begin{array}{l}\text { Total } \\
\text { Invest- } \\
\text { ment* }\end{array}$ & $\begin{array}{l}\text { Total } \\
\text { Profit }\end{array}$ & $\begin{array}{l}\text { Avg. } \\
\text { No. of } \\
\text { Months }\end{array}$ & $\begin{array}{l}\text { Annual } \\
\text { Yield }\end{array}$ \\
\hline $\begin{array}{l}\text { Air Reduction } \\
\text { American Distilling } \\
\text { Amer. Machine \& F. } \\
\text { Armour } \\
\text { Ashland Oil } \\
\text { Aurora Plastics } \\
\text { Avco } \\
\text { Beaunit } \\
\text { Celanese } \\
\text { Collins Radio } \\
\text { Comb. Engineering } \\
\text { Continental Baking } \\
\text { Coperw. Steel } \\
\text { Crowell Coliier } \\
\text { Dow Chemical } \\
\text { Dresser } \\
\text { Food Falr } \\
\text { Gen. American Oil } \\
\text { General Instr. } \\
\text { General Time } \\
\text { Grace (W. R.) } \\
\text { Granite City Steel } \\
\text { Hunt Foods } \\
\text { Int. T \& } \mathrm{I} \\
\text { Litton } \\
\text { Macy } \\
\text { Northrop } \\
\text { Olin.Math. } \\
\text { Oxford Paper } \\
\text { Phil. Petroleum } \\
\text { Rohr } \\
\text { Scott Paper } \\
\text { Sinclair } \\
\text { Stevens, J. P. } \\
\text { United Aircraft }\end{array}$ & $\begin{array}{c}6 \\
8 \\
\text { None } \\
3 \\
3 \\
4 \\
5 \\
2 \\
1 \\
6 \\
15 \\
11 \\
12 \\
2 \\
3 \\
5 \\
10 \\
14 \\
1 \\
3 \\
\text { None } \\
5 \\
\text { None } \\
2 \\
\text { None } \\
2 \\
11 \\
10 \\
2 \\
12 \\
12 \\
7 \\
4 \\
2 \\
3\end{array}$ & $\begin{array}{r}8684 \\
11229 \\
\cdot 3 \\
3745 \\
5332 \\
5491 \\
9855 \\
2138 \\
1034 \\
9426 \\
23332 \\
16320 \\
18400 \\
3125 \\
1881 \\
7753 \\
13366 \\
19942 \\
1583 \\
3926 \\
69778 \\
. \quad 5 \\
3766 \\
28 \\
2680 \\
20907 \\
16057 \\
2849 \\
21800 \\
20809 \\
11340 \\
5976 \\
3485 \\
4943 \\
\end{array}$ & $\begin{array}{r}120 \\
-312 \\
212 \\
-77 \\
188 \\
78 \\
-38 \\
45 \\
109 \\
329 \\
-536 \\
-45 \\
85 \\
73 \\
538 \\
-53 \\
130 \\
94 \\
-13 \\
-210 \\
-210 \\
97 \\
-18 \\
-18 \\
51 \\
185 \\
37 \\
-364 \\
-206 \\
-42 \\
272 \\
108 \\
31 \\
\end{array}$ & $\begin{array}{r}17.3 \\
19.4 \\
10.0 \\
10.0 \\
5.0 \\
6.0 \\
11.2 \\
9.0 \\
5.0 \\
2.0 \\
7.5 \\
11.8 \\
10.9 \\
9.0 \\
5.7 \\
10.2 \\
20.0 \\
16.4 \\
1.0 \\
11.7 \\
18.0 \\
18.0 \\
3.0 \\
14.0 \\
14.5 \\
12.4 \\
12.0 \\
15.1 \\
10.3 \\
11.4 \\
18.3 \\
5.0 \\
8.0 \\
\end{array}$ & $\begin{array}{r}.96 \% \\
-1.71 \\
6.79 \\
-3.46 \\
8.21 \\
.85 \\
2.36 \\
10.44 \\
6.90 \\
22.56 \\
-3.34 \\
-.26 \\
3.63 \\
8.17 \\
8.15 \\
-.23 \\
.48 \\
71.16 \\
-.34 \\
-2.06 \\
-2.06 \\
10.28 \\
-. .55 \\
-.34 \\
1.09 \\
1.29 \\
1.32 \\
-1.14 \\
-.39 \\
2.98 \\
7.42 \\
.93 \\
\end{array}$ \\
\hline Total & 186 & $\$ 287952$ & $\$ 868$ & 11.9 & $.30 \%$ \\
\hline
\end{tabular}

*Based on purchasing one bond per transaction, and assuming $70 \%$ margin requirement on accompanying short sale. 
is the persistent secular uptrend in the stock market over the test period. The full hedger is, in essence, a conservative bear; conservative or not, a short seller earns less in a generally rising market: There were not enough short periods of sustained decline to generate significant overall profits, especially in view of the additional investment represented by the bond purchase. The filter mule produced a lower annual return than the target rule for two reasons: First, the fact that the transactions took, on average, longer to complete; and secondly, because of the tendency for declining stock prices to reverse themselves abruptly and to rise to a disengagement price higher than the target level. The latter phenomenon was accentuated by the lack of price information between the mid-month points included in the data gathered. It is unlikely, however, that the filter rule would have performed any better than the target rule in any case. Therefore, of the two, the target rule was selected for further testing.

Variability of Return

Table XXVI, showing the size distribution of gains and losses in the full hedge transactions, can be compared directly with the similar table on page 216 covering the partial hedge transactions. Had the full hedge technique worked perfectly, there would have been no losses, just as there would have been no losses in the partial hedge. In the full hedge, however, 


\section{TABLE XXVI}

\section{SIZE DISTRIBUTION OF GAINS AND LOSSES, ALL COMPLETED FULL HEDGE \\ TRANSACTIONS}

\begin{tabular}{|c|c|c|c|c|}
\hline \multirow[b]{2}{*}{$\begin{array}{c}\text { Size of Gain or } \\
\text { Loss Per } \\
\text { Transaction }\end{array}$} & \multicolumn{2}{|c|}{ Target Rule } & \multicolumn{2}{|c|}{ Filter Rule } \\
\hline & $\begin{array}{c}\% \text { of Tran- } \\
\text { sactions } \\
\text { in Each } \\
\text { Category }\end{array}$ & $\begin{array}{l}\text { Accumu- } \\
\text { lated } \\
\%\end{array}$ & $\begin{array}{l}\text { \% of Tran- } \\
\text { sactions } \\
\text { in Each } \\
\text { Category }\end{array}$ & $\begin{array}{l}\text { Accumu- } \\
\text { lated } \\
\%\end{array}$ \\
\hline $\begin{array}{l}\text { Gains } \\
\$ 200 \text { or more } \\
175-199 \\
150-174 \\
125-149 \\
100-124 \\
75-99 \\
50-74 \\
25-49 \\
0-24\end{array}$ & $\begin{array}{l}0.0 \% \\
1.1 \\
2.7 \\
3.8 \\
3.2 \\
4.3 \\
6.5 \\
13.5 \\
15.1\end{array}$ & $\begin{array}{l}0.0 \% \\
1.1 \\
3.8 \\
7.6 \\
10.8 \\
15.1 \\
21.6 \\
35.1 \\
50.2\end{array}$ & $\begin{array}{l}0.0 \% \\
0.0 \\
1.1 \\
3.8 \\
3.8 \\
3.8 \\
6.5 \\
16.1 \\
15.1\end{array}$ & $\begin{array}{l}0.0 \% \\
0.0 \\
1.1 \\
4.9 \\
8.7 \\
12.5 \\
19.0 \\
35.1 \\
50.2\end{array}$ \\
\hline $\begin{array}{l}\text { Losses } \\
\$ 1-25 \\
26-50 \\
51-75 \\
76-100 \\
101-125 \\
126-150 \\
151-175 \\
176-200\end{array}$ & $\begin{array}{l}19.8 \% \\
15.6 \\
8.1 \\
2.6 \\
1.6 \\
1.1 \\
.5 \\
.5\end{array}$ & $\begin{array}{l}70.0 \% \\
85.6 \\
93.7 \\
96.3 \\
97.9 \\
99.0 \\
99.5 \\
100.0\end{array}$ & $\begin{array}{c}19.8 \% \\
15.1 \\
7.4 \\
3.2 \\
1.1 \\
1.1 \\
.5 \\
1.6\end{array}$ & $\begin{array}{l}70.0 \% \\
85.1 \\
92.5 \\
95.7 \\
96.8 \\
97.9 \\
98.4 \\
100.0\end{array}$ \\
\hline $\begin{array}{l}\text { Average Invest- } \\
\text { ment Per } \\
\text { iransaction }\end{array}$ & \multicolumn{2}{|c|}{$\$ 1548$} & \multicolumn{2}{|c|}{$\$ 1548$} \\
\hline
\end{tabular}

losses of various sizes occurred in fifty per cent of the transactions, compared with only about twenty-five per cent of the partial hedge transactions. One would also expect to see, in the full hedge, a more frequent occurrence of larger dollar profit figures and a less frequent occurrence of 
small to medium-sized profit figures. This expectation did not materialize.

Though losses were as frequent as gains, they were, on average, smaller than the gains, thus accounting for the positive, albeit small, overall yields. As in the partial hedge, if worthwhile profits are attainable in the full hedge, they must come from above-average transactions selected from among the general range of transactions.

\section{Refinements}

In the partial hedge, the $X$ and $Y$ equations proved of value in weeding out low-profit transactions. In the full hedge, unfortunately, the $Y$ equations did not appear very effective for this purpose. Table XXVII shows the transactions with originally expected profits of $\$ 150$ or more, completed under the modified target rule. The 0.63 per cent yield reported previously for the target rule did increase to 1.13 per cent, a significant increase statistically speaking but not of sufficient financial significance to attach any importance to the predictive power of the $Y$ equations. And there is little further meaningful correlation. Restricting the transactions to those with expected $Y^{\prime} s$ of $\$ 200$ or nore (not shown in the tables) reduces the overall annual yield again--to 0.58 per cent. At $\$ 250$ or more, the yield rises to 1.34 per cent. And at $\$ 300$ or more, the yield declines to 0.99 per cent. This pattern is, of course, convincing 
evidence of the impotency of the $Y$ equations in sorting out the transactions on a refined basis.

\section{TABLE XXVII}

SELECTED FULL HEDGE TRANSACTIONS COMPLETED UNDER THE TARGET RULE

All Transactions With Expected Y of $\$ 150$ or More

\begin{tabular}{|c|c|c|c|c|c|}
\hline Description & $\begin{array}{l}\text { No of } \\
\text { Transac- } \\
\text { tions }\end{array}$ & $\left\{\begin{array}{l}\text { Total } \\
\text { Invest- } \\
\text { ment* }\end{array}\right.$ & $\begin{array}{l}\text { Total } \\
\text { Profit }\end{array}$ & $\begin{array}{l}\text { Avg } \\
\text { No. of } \\
\text { Months }\end{array}$ & $\begin{array}{l}\text { Annual } \\
\text { Yield }\end{array}$ \\
\hline $\begin{array}{l}\text { American Distilling } \\
\text { Armour } \\
\text { Ashland Oil } \\
\text { Aurora Plastics } \\
\text { Avco } \\
\text { Beaunit } \\
\text { Collins Radio } \\
\text { Comb. Engineering } \\
\text { Cont. Baking } \\
\text { Coperw. Steel } \\
\text { Crowell Collier } \\
\text { Gen. American Oil } \\
\text { General Time } \\
\text { Granite City Steel } \\
\text { Int. T \& T } \\
\text { Northrop } \\
\text { Olin. Math. } \\
\text { Pnil. Pet. } \\
\text { Rohr } \\
\text { Scott Paper }\end{array}$ & $\begin{array}{r}1 \\
1 \\
3 \\
4 \\
2 \\
1 \\
4 \\
5 \\
4 \\
3 \\
1 \\
6 \\
1 \\
4 \\
2 \\
11 \\
3 \\
8 \\
12 \\
4\end{array}$ & $\begin{array}{r}1769 \\
1423 \\
5332 \\
5491 \\
3756 \\
1104 \\
6477 \\
8364 \\
6545 \\
5153 \\
2015 \\
8628 \\
1316 \\
5308 \\
3766 \\
20907 \\
4601 \\
14592 \\
10809 \\
6524\end{array}$ & $\begin{array}{r}\$- \\
130 \\
-77 \\
188 \\
33 \\
-29 \\
16 \\
277 \\
34 \\
32 \\
48 \\
392 \\
51 \\
-74 \\
97 \\
169 \\
-22 \\
-47 \\
24 \\
-45\end{array}$ & $\begin{array}{r}3.0 \\
2.0 \\
5.0 \\
5.0 \\
9.5 \\
12.0 \\
2.3 \\
6.8 \\
7.8 \\
5.0 \\
3.0 \\
17.5 \\
8.0 \\
16.5 \\
3.0 \\
8.3 \\
10.7 \\
15.0 \\
10.2 \\
10.5\end{array}$ & $\begin{array}{r}-2.00 \% \\
54.60 \\
-3.46 \\
8.21 \\
1.01 \\
-2.60 \\
1.04 \\
5.82 \\
.77 \\
1.44 \\
9.20 \\
3.09 \\
5.70 \\
-.95 \\
10.28 \\
1.16 \\
-.45 \\
-.24 \\
.13 \\
.69\end{array}$ \\
\hline Total & 80 & $\$ 133880$ & $\$ 1188$ & 9.4 & $1.13 \%$ \\
\hline
\end{tabular}

*Based on purchasing one bond per transaction, and assuming $70 \%$ margin requirement on accompanying short sale.

Table XXVII is a summary table showing the various yields produced in the full hedge applications test. In addition to the yields discussed, it reflects the improvement 
TABLI XXVIII

SUMMARY OF RATES OF RETURN ON THE
FULI HEDGE'*

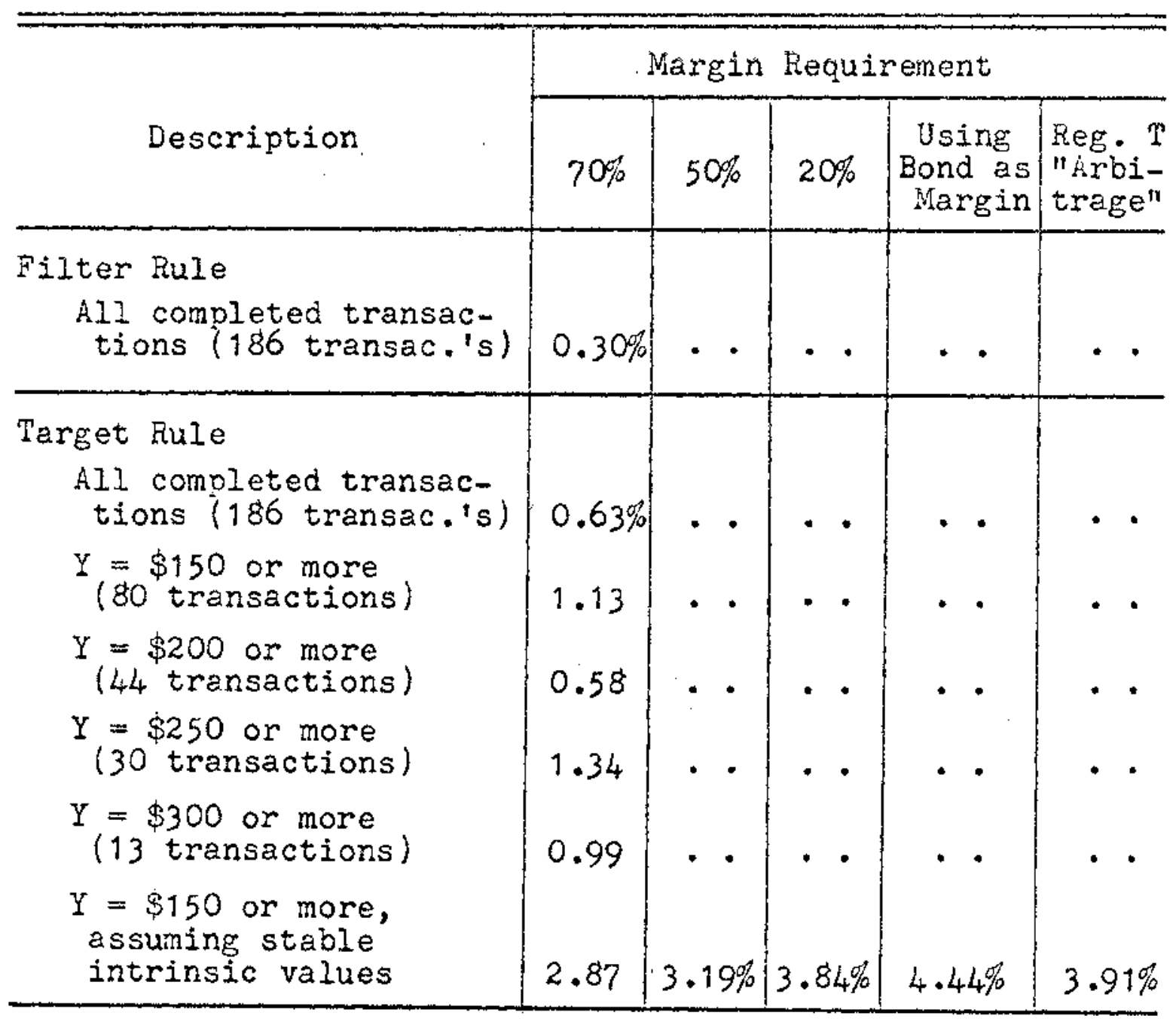

*Before taxes, commissions, interest received, and dividends paid.

introduced by the assumption of stable intrinsic values, and by the assumption of smalier short sale margin requirements, including the special arrangements discussed in the previous chapter. The highest rate of return attained in the full hedge was 4.44 per cent. This occurred under the modified 
target rule, with expected $Y$ 's restricted to those of $\$ 150$ or more, with stable intrinsic values assumed, and by using the bond as margin to cover short sales. The "arbitrage" provision of Regulation $T$ was of no help. In fact, use of that arrangement dropped the yield to 3.91 per cent. The reason is that margin loans on bonds, unlike short sale loans, require the payment of interest, and the assumed 5 per cent interest rate used in the computation was greater than the rate earned.

In the partial hedge, it was estimated that brokerage commissions cancel against the excess of bond interest received over dividends of one per cent paid on short sales (see page 224). In the full hedge, however, short positions are roughly double those maintained in the partial hedge. This means that approximately one percentage point must be subtracted from the yields show in Table XXVIII. That is, this one percentage point represents an unrecovered dividend payout associated with the larger short position.

The tax status is roughly comparable with that of the partial hedge.

Conclusion

Like the partial hedge, the full hedge is a technique designed to appeal to highly risk-conscious investors. Hence, rates of return as large as on riskier ventures would not be expected. However, the range of rates from 0.30 to 4.44 per cent 
-or from minus 0.70 to plus 3.44 per cent after adjustment for commissions, interest received, and taxes paid--is well below the range of 5.17 to 9.52 per cent attained on the partial hedge. It must be concluded, therefore, that the full hedge is an irrational investment technique--and, because of that fact, sheds no further light on the degree of perfection prevailing in the secondary convertible bond market. 
CHAPTER VII

\section{SUMMARY OF FINDINGS}

As was mentioned in Chapter I, the study was designed to produce three main types of information: (1) Conclusions regarding the degree of perfection in the primary and secondary convertible bond markets; (2) the profit potential of the various investing and hedging techniques in the convertible market, expressed as annual rates of return; and (3) a judgment on whether each technique can be classified as rational or irrational.

The Primary Convertible Market

In the primary convertible bond market, the hypothesis that severe and chronic imperfection pervades that mariset was clearly verified. A speculator able to bridge the gap between offering prices of new convertibles and initial prices in secondary trading in the $1956-68$ period covered in the study could have earned before-tax profits ranging from 55.7 to 2896.9 per cent per annum, depending upon the margin percentage and the ability of the speculator to keep his funds working continuously. From a broad economic viewpoint, such imperfection in the primary market denotes a failure of real resources to move efficiently from savers to producers. The imperfection is attributabie to underpricing of new convertible issues by investment bankers. 
The Secondary Convertible Market

The investment or hedging techniques in the secondary convertible market fell into three categories: Those involving an external comparison with the stock and straight debt markets; those involving a strictly internal application within the secondary convertible market; and the hedging techniques which represent a conbined internal/external approach.

In the external comparisons, long-run rates of return on convertibles were compared with similar rates on the convertiblematching stocks, on the fill range of common stocks on the New York Stock Exchange, and on straight bonds. Over the entire period from 1956 to 1968 , the rate of return resulting from random buy-and-hold commitments in convertibles was 6.4 per cent (before taxes). Whether direct buy-and-hold comitments in convertibles are declared to constitute a rational investment technique depends upon the assumption made about the population of common stocks against which the convertibles are compared. Given a choice of random investments in " listed convertibles, random investments in the convertiblematching stocks, or random commitments in straight bonds, the convertibles are rational for investors wiling to assume more risk than would be involved in the straight debt issues but less than would be involved in the matching common stocks. This is precisely the sort of investor convertibles are famous for satisfying. The 6.4 per cent return on the convertibles compares with 8.4 per cent on the convertible-matching stocks 
and about 5 per cent on straight bonds--a rate structure accounted for largely by utility differences between the three categories of securities. Not only is the investment approach rational, but a high degree of perfection is indicated in the secondary convertible bond market relative to external markets.

The investor is not, of course, limited to the convertiblematching stocks in making commitments in stocks. If the comparison is made between buy-and-hold commitments in convertibles and similar commitments among the general population of listed common stocks (limited to those on the New York Stock Exchange in the study), the 6.4 per cent return on convertibles compares rather unfavorably with a return of over 12 per cent on the stocks, even after making allowances for risk/utility differences. In comparison with the imperfection prevailing in the primary market, of course, this imperfection in the secondary market is still only moderate. In the secondary markets, a completely rational investor, however, would either make some sort of selective or nonrandom purchase of convertibles (the rationale' for which was not pursued in the present study) or else make random commitments among the general population of listed stocks.

$S_{t}$ ill within the category of direct buy-and-hold commitments in convertibles, the peak-to-peak rate on convertibles ranged from 5.5 to 6.4 per cent, the trough-to-trough rates from 4.9 to 8.0 per cent; the peak-to-trough rates from 3.1 
to 4.8 per cent; and the trough-to-peak rates from 7.2 to 10.3 per cent, The peak-to-peak and trough-to-trough rates do virtually nothing to add to or alter the conclusions just drawn. The peak-to-trough rates revealed the advantages of convertibles, relative to their matching stocks, in a declining stock market; but there was no advantage over Iisted stocks in general. The trough-to-peak rates clearly substantiated the thesis that convertibles are a bad bargain in a rising stock market. Whether directional movements in the stock market can, in fact, be predicted is a question not investigated in the present study. Hence, nothing can be said about the rationality of an investment technique based on such an intent.

Turning now to investment techniques applied internally within the iisted convertible bond market, it was found that of three short-term trading strategies tested, the first approach proved to be a rational one possessing the ability to take advantage of moderate imperfections in the secondary bond market. This technique, described on pages 115-116, involved buying convertibles whose market prices were below some absolute price level ( $\$ 1000$ in the study); the technique produced before-tax annual returns ranging from 7.4 per cent to 25.5 per cent, depending upon the termination rule employed and the use of margin. The second strategy, described on page 117, consisted of buying each convertible issue in a sample at every six-month interval, regardless of the market price, 
and selling out on the basis of a moving stop-loss rule. This second technique, relative to the first trading technique at least, was apparently irrational because it produced a return ranging from only 6.9 to 10.7 per cent. And it shed no further light on the question of secondary market imperfection. The third trading strategy, described on pages 118-124, involved the construction and application of a speculative-premium index. It produced an overall return ranging from 11.4 to 32.4 per cent, but fortuitous general price movements in the stock market are believed to have heavily influenced these returns. The technique is appealing on a conceptual basis but is difficult to use in practice or to test empirically. The evidence as to its rationality or irrationality is inconclusive. Nor was anything more learned about the degree of perfection or imperfection in the secondary convertible market.

Another type of internal analysis employed in the study was the comparison of the relative profitability of various subgroups of convertibles. Five different types of subgroups were analyzed. Concentration of cormitments in three of the five subgroups was deemed a rational investment strategy. These three subgroups are bonds convertible into a relatively large number of common shares, bonds originally selling at a relatively low price (a strategy closely related to the first of the three trading strategies), and bonds originally marketed via rights offerings rather than to the general investing 
public. The apparent ability of these types of selective commitments to earn above-average returns denotes a moderate degree of imperfection in the secondary convertible market. ${ }^{1}$ One of the two remaining subgroups, the categorization by Moody's ratings, revealed no imperfection and was deemed irrational (or at least not positively rational) as an investment strategy. The other, the grouping by industrial category, revealed some imperfection in historical markets, but was not deemed rational as a future strategy.

Turning, finally, to the combination internal/external techniques, attention focuses on the two hedging techniques --the partial hedge and the full hedge. The partial hedge is a highly conservative technique tailored to the needs of very risk-conscious investors. Rates of return generated by the partial hedge should, therefore, not be compared with rates of return on common stocks. A more illuminating comparison is with the buy-and-hold rates on convertibles and with the rate of return from commitments in straight debt issues. On either basis, the partial hedge can be declared rational because of the rates of return ranging up to 9.5 per cent with the use of the "arbitrage" provisions of Regulation T of the Federal Reserve Board. This range of returns is still rather moderate, however, thus denoting no serious degree of

${ }^{1}$ As explained on pages 107 and 108 , actual rates of return were not computed on the subgroups; two relative profitability measures were employed instead. 
imperfection in the secondary market for convertibles listed on the New York Stock Exchange.

The full hedge, because of its maximum return of only 3.4 per cent, is irrational. And it reveals nothing conclusive about the level of perfection in the market.

\section{Final Remarks}

In final summary, then, the hypothesis that severe and chronic imperfection exists in the primary convertible bond market was verified; during the 1956-68 period studied, large profits would have been available to a speculator operating between the secondary and primary markets. The hypothesis that the secondary convertible bond market is a nearly perfect market was verified in the sense that the imperfection in the secondary market is moderate compared with the imperfection in the primary market. Sufficient imperfection exists, however, to make certain of the investment and hedging techniques investigated in the study rational from the viewpoint of a profit-seeking investor, even after making allowances for differences in willingness to accept risk.

While pursuing the main course of the study, several topics ripe for future research were uncovered. These include: The need for a better quality-rating system for convertibles (and one that differs from the rating system used on straight bonds); the need for additional information on the influence of institutional investors in the convertible bond markets; 
and the possibility of severe imperfections in primary securities markets other than the convertible market. 
APPENDIX 


\section{APPENDIX}

The following are lists of the convertible issues included in the samples used in the study. Except for the twelve and twenty-nine-issue samples, data were collected on the matching stocks as well as the convertibles shown.

$$
\text { The Twenty-Nine-Issue Sample }
$$

This sample was used for general purposes in Chapter

II.

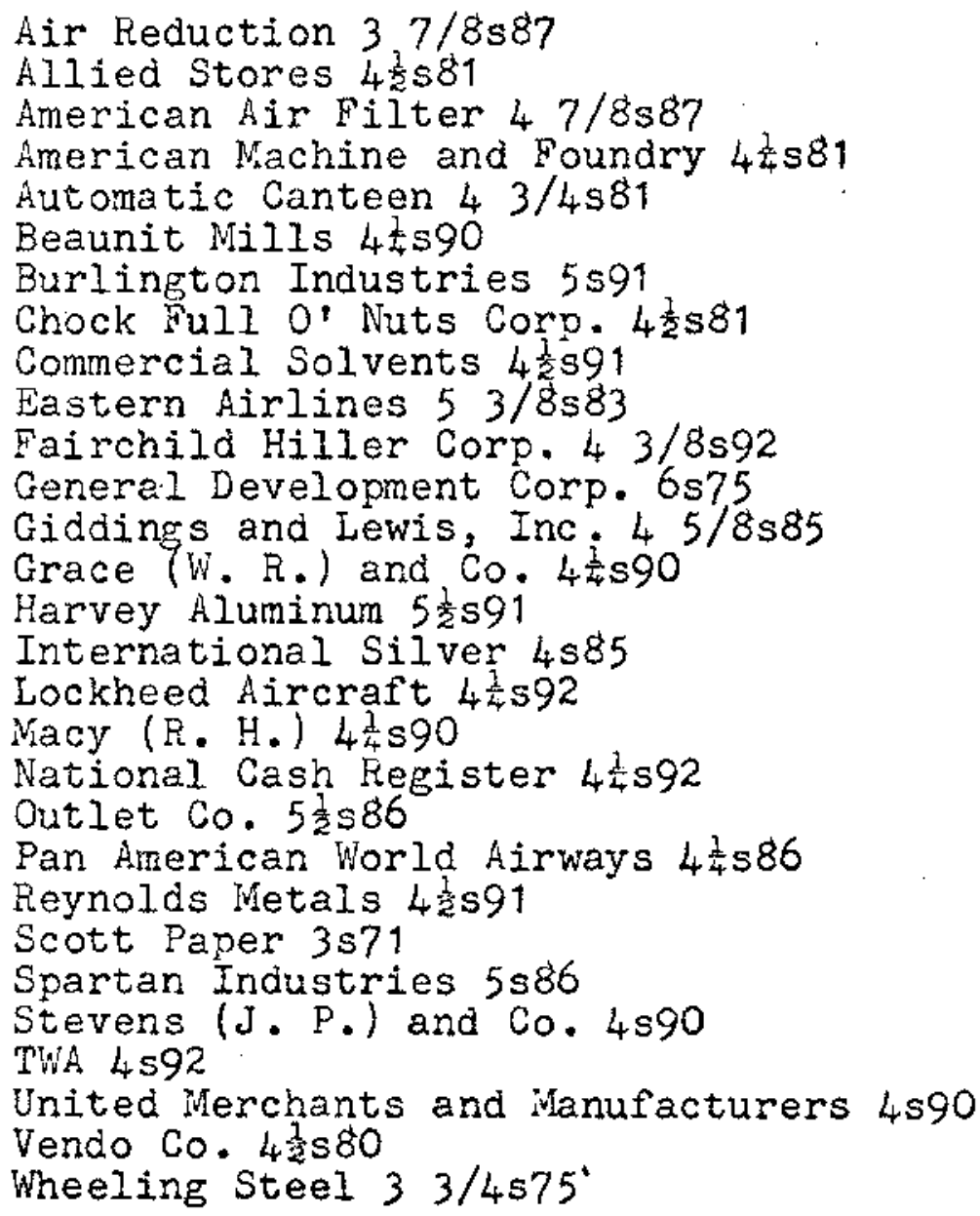


The Eighty-Issue Sample

The eighty-issue sample was used for general purposes in Chapter II and, with three deletions, for the prinary market analysis presented in chapter III and the study of direct commitments in convertibles presented in Chapter IV. The three deletions are marked with an asterisk.

Air Reduction $37 / 8$ s 87

Aldens $550^{\circ} 0$

Allegheny Ludlum Steel $4 \mathrm{~s} 81$

Allied Stores $4 \frac{1}{2} \mathrm{~s} 81$

American Air Filter $47 / 8$ s 87

American Distilling $43 / 8586$

American Hoist $43 \% 4592$

American Machine and Foundry $4 \frac{1}{4} 881$

American Telephone and Telegraph $37 / 8$ s67

Atlantic Refining $4 \frac{1}{2} 587$

Aurora Plastics $45 / 8580$

Automatic Canteen $43 / 4581$ (now Canteen Corp.)

Baxter Laboratories 4587

Beaunit Milis $4 \frac{1}{2} 590$

Bethlehem Steel 3 s 80

Bobbie Brooks $5 \frac{1}{4} \mathrm{~s} 81$

Boeing $4, \frac{1}{2} 80$

Burroughs $4 \frac{1}{2} s 81$

Cenco Instruments $5 \frac{3}{4} 586$

Chock Fuil o' Nuts 43581

Cluett, Peabody $4 \frac{1}{4} 584$

Collins Radio $43 / 4580$

Combustion Engineering $33 / 8$ s 81

Commercial Solvents $4 \frac{5}{2} 591$

Consolidated Edison 4573

Continental Baking $43 / 8583$

Copperweld Steel 5579

Douglas Aircraft 4577

Dow Chemical 3882

Eastern Airlines $5 \$ 92$

Eastern Stainless Steel $5 s 73$

Fairchild Hiller $43 / 8592$

Fansteel Metallurgical $43 / 4576$

Food Fair 4 s79

General American Oil $43 / 4584$

General Development Corp. 6s75

General Telephone Corp. $4 \frac{1}{2} 577$ (now Gen. Tel. and El.)

General Telephone and Electronics 4590

Giddings and Lewis $45 / 8$ s $85 \%$

Grant (W. T.) 4 s90 


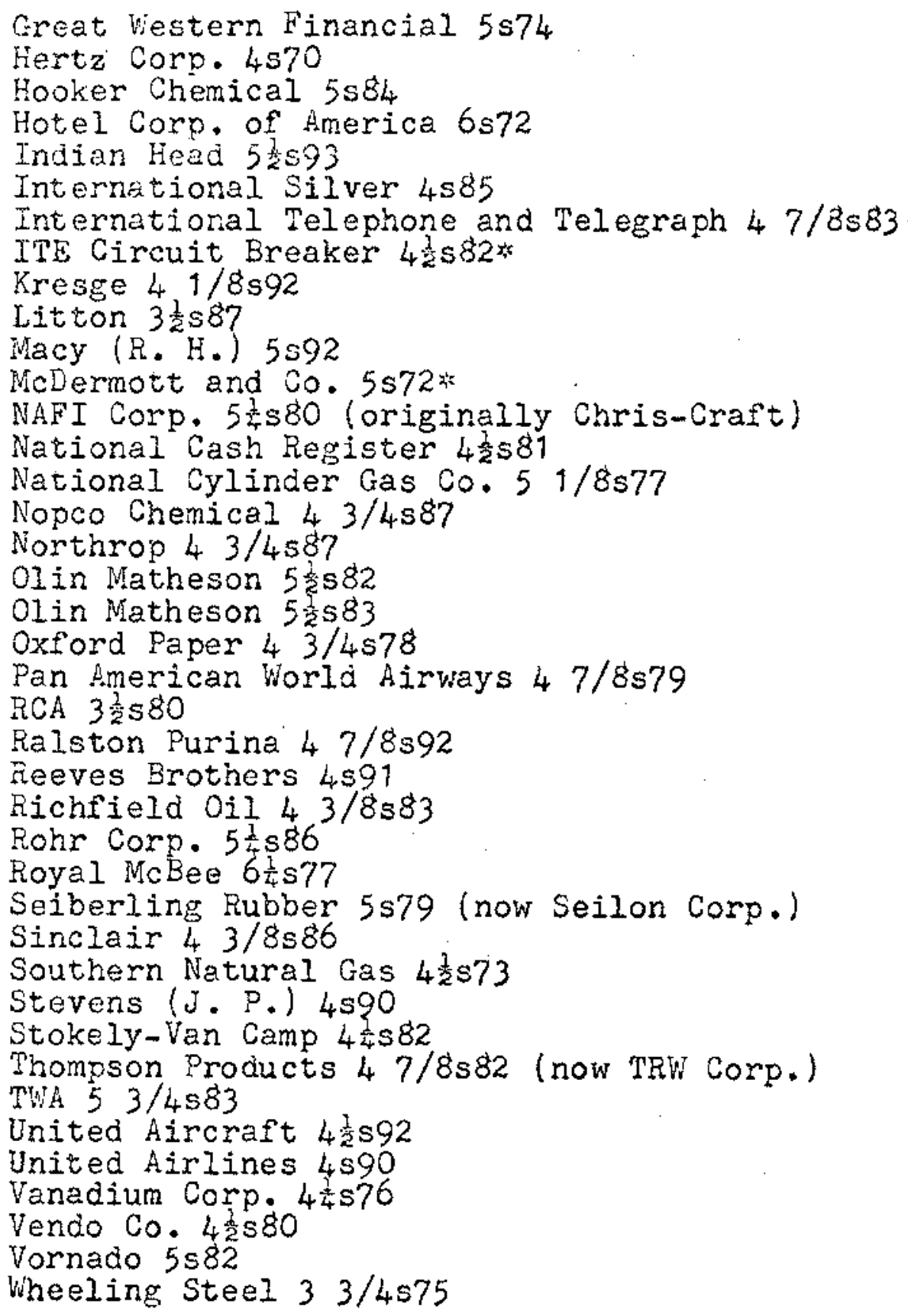

The Thirty-Six-Issue Sample

This sample was used for the partial hedge of Chapter $V$ and the full hedge of Chapter VI.

Air Reduction $37 / 8$ s 87 American Distiling $43 / 8$ s86 American Machine and Foundry $4 \frac{1}{4} 581$ 


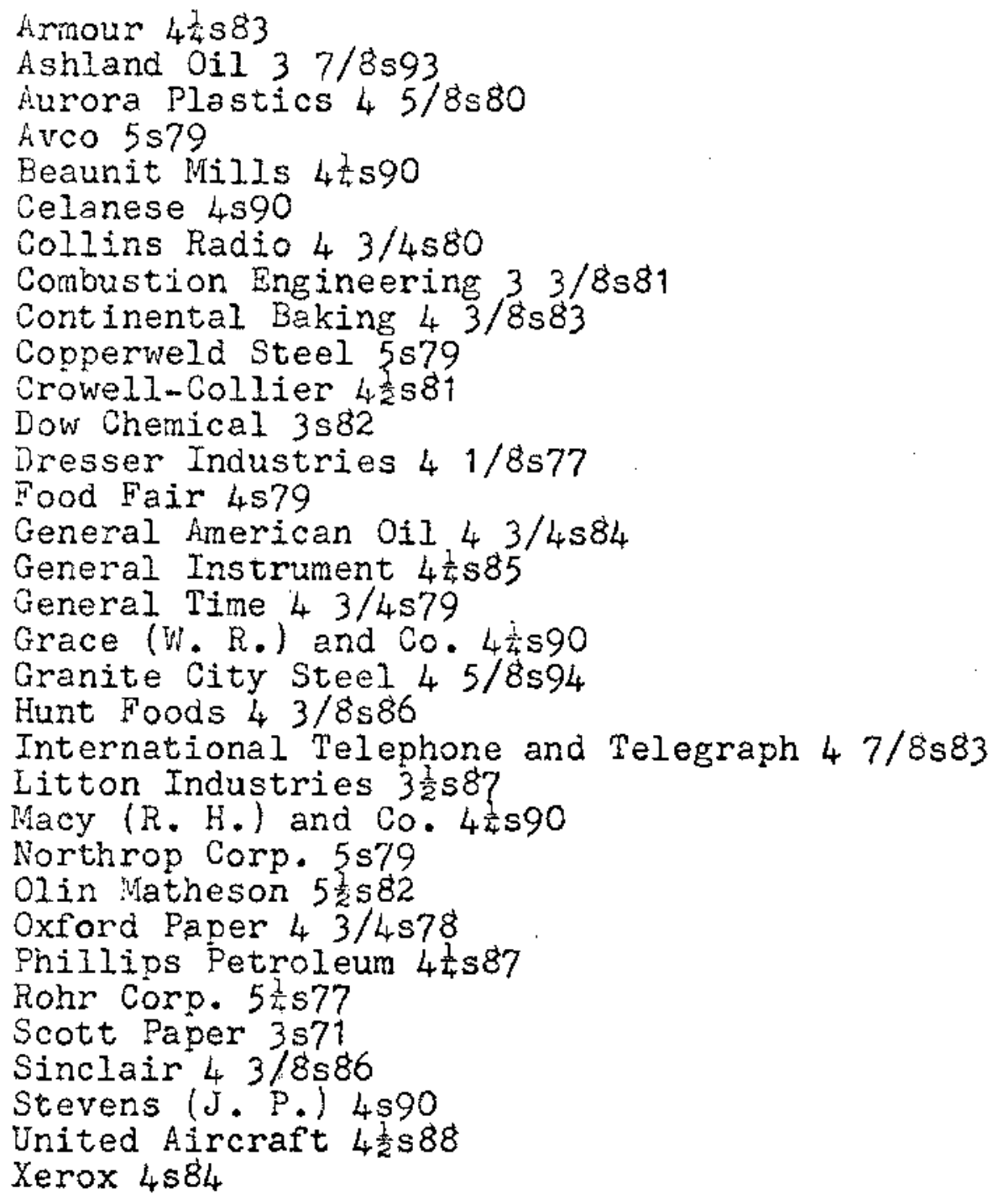

The Twelve Convertibles Issued Since March, 1968

American Broadcasting 5593

American Hoist 5593

Burroughs 3 3/4\$93

Chase Manhattan Bank $47 / 8593$

De Giorgio Corp. $53 / 4593$

Indian Head $5 \frac{1}{2} 593$

Medusa Portland Cement $53 / 4588$

Ogden Corp. 5s93

Pueblo Supermarkets $5 \frac{1}{4} 588$

Sundstrand 5593

United Utilities, Inc. 5593

White Motor Corp. $5 \frac{1}{4} s 93$ 
BIBLIOGRAPHY

。 


\section{BIBLIOGRAPHY}

\section{Books}

Atkinson, Thomas R., Trends in Corporate Bond Quality, New York, National Bureau of Economic Research, distributed by Columbia University Press, 1967.

Barnes, Leo, Your Investments, 10th ed., Larchmont, New York, American Research Council, Inc., 1963.

Canadian Convertjble Debenture Issues, Toronto, McLeod, Young, Weir and Co., Ltd., 1952 .

Dewing, Aruthur, The Financial Policy of Corporations, 4th ed., 2 vol.'s, New York, Ronald Press, 1941.

, The Financial Policy of Corporations, 5th ed., 2 vol.'s, New York, Konald Press, 1953.

Donaldson, Elvin F., Corporate Finance, New York, The Ronald Press, 1957 .

Drew, Garfield, New Methods for Profit in the Stock Market, Boston, Metcalf Press, 1955.

Edwards, Robert Davis and John Magee, Technical Analysis of Stock Trends, Springfield, John Magee, 1958.

Friend, Irwin and others, Investment Banking and the New Issues Market, Cleveland, The World Publishing Co,, 1967.

Graham, Benjamin and David L. Dodd, Security Analysis, Principles and Technique, 3rd ed., New York, McGraw-Hill Book Co., Inc., 1951 .

Graham, Benjamin, David L. Dodd, and Sidney Cottle, Security Analysis, Principles and Technique, 4 th ed., New York, MeGraw-Hill Book Co., Inc., 1962.

Hanson, William C., Capital Sources and Major Investing Institutions, New York, Simmons-Boardman Publishing Corp., 1963.

Hickman, W. Braddock, National Bureau of Economic Research, Statistical Measures of Corporate Bond Financing Since 1900 , Princeton University Press, 1960. 
Hicks, John R., Value and Capital, Oxford, Oxford University Press, 1939.

Investment Bankers Association of America, Fundamentals of Investment Banking, Englewood Cliffs, N.J., PrenticeHaIl, Ine., 1949. .

Kassouf, S. T., Evaluation of Convertible Securities, New York, Analytic Investors, Inc., 1962 .

Keynes, John Maynard, the General Theory of Employment, Interest, and Money, 1st Harbinger ed., New York, Harcourt, Brace and World, Inc., 1964.

Leness, George J., Gillette K. Martin, and Roger T. Gilmartin, New Money for Business, Techniques of Long-term Corporate Financing, New York, McGraw-Hili Book Co., Inc., 1956 .

Pilcher, 0 . James, Raising Capital with Convertible Securities, Ann Arbor, Bureau of Business Research, University of Michigan, 1955.

Rollins, Montgomery, Convertible Securities, 2nd ed., Boston, Financial Publishing Co., 1913.

Shao, Stephen $P_{\text {. }}$ Mathematics of Finance, Cincinnati, SouthWestern Publishing Co., 1962 .

Taylor, W. Bayard, Financial Policies of Business Enterprise, New York, D. Appleton-Century, 1942 .

Walker, Enest W., Essentials of Financial Management, Englewood CIiffs, N.J., Prentice-HaII, Inc., 1965.

Weaver, Mark, The Technique of Short Selling, Palisades Park, N. J., Investors Library, 1963.

Williams, John Burr, The Theory of Investment Value, NorthHolland Publishing Co., Amsterdam, 1938.

Articles

"A Dent in Convertibles," Fortune, $\operatorname{LXXIV}\left(0_{c t .}, 1966\right), 242$, 247-50.

Barnes, Leo, "What Difference Does Knowledge Make?, Financial Analysts Journal, XXI (Sept.-Oct., 1965), 60-68. 
Brigham, E. F., "Analysis of Convertible Debentures, Theory and Some Empirical Evidence," Journal of Finance, XXI (March, 1966), 35-54.

Broman, Keith L., "The Use of Convertible Subordinated Debentures by Industrial Firms 1949-59," The Quarterly Review of Economics and Business, III (spring, 1963), $65-75$.

"Convertible Debentures Post Gains of $15 \%$ Since September on Heavy Institutional Buying," Business Week (Dec. 17, 1966), p. 127.

Cootner, Paul H., "Stock Prices: Random vs. Systematic Changes," Industrial Management Review, III (Spring, 1962), 24-45.

Fama, Eugene F., "Random Walks in Stock Market Prices," Financial Analysts Journal, XXI (Sept.-Oct., 1965), $55-59$.

Fama, Eugene F., "The Behavior of Stock-Market Prices," Journal of Business, University of Chicago, XXXVIII TJan., 1965T, 34-105.

Fisher, Lawrence and James H. Lorie, "Rates of Return on Investments in Comnon Stocks;" The Journal of Business, University of Chicago, XXXVII (Jan., 1964), 1-21.

Fisher, Lawrence and James H. Lorie, "Rates of Return on Investments in Common Stocks, the Year-by-Year Record, 1926-1965," reprint, supplied by Merrill Lynch, Pierce, Fenner and Smith, Inc., of article scheduled to appear in the July, 1968, Journal of Eusiness, Vol. XXXX.

Fisher, Lawrence, "Outcomes for 'handom' Investments in Common Stocks Listed on the New York Stock Exchange," Journal of Business, University of Chicago, XXXVIII TApri1, 1965), 149-61.

Fraine, Harold G. and Robert H. Mills, "Effect of Defaults and Credit Deterioration on Yields of Corporate Bonds," The Journal of Finance, XVI (Sept., 1961); 423-34.

"Growing Power of Institutional Investors Examined at AMA Meeting," Prusts and Estates, CV (Dec., 1966), 11981205 .

Hershman, Arlene, "New Style in Convertibles," Dun's Review, XCI (March, 1968), 43, 44 . 
Hirshleifer, Jack, "Risk, the Discount Rate, and Investnent Decisions," American Economic Review, LI (May, 1961), $112-20$.

"Important, But Not All-Powerful," Business Week (July 18, 1964), pp. 93, 94 .

Keith, C. C., "Convertible Securities and Stock Purchase Warrants, "Rocky Mountain Law Review, II (Nov., 1929), $16-31$.

Kirk, John, "A Critical Look at the Institutional Investor," Banking, IX (March, 1968), 8े-14.

Krasney, Samuel A., "Institutionals and How to Work With Them," Public Relations JournaI, XXIV (April, 1968), $11-13$.

Latane, Henry A., "Criteria for Choice Among Risky Ventures," The Journal of Political Economy, LXVII (April, 1959),

McKenzie, Robert R., "Convertible Debentures, 1956-65,"

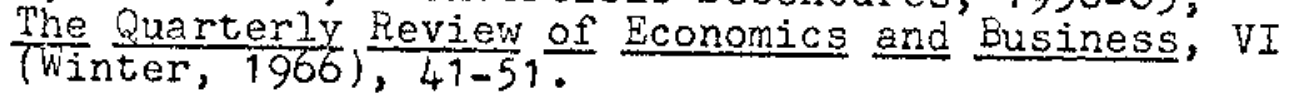

Molodovsky, Nicholas, "Stock Values and Stock Prices," The

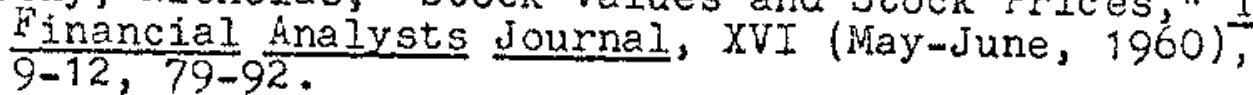

Molodovsky, Nicholas, "The Many Aspects of Yields," Financial $\frac{\text { Analysts Journal }}{77-86}$. XVIII (Viach-April, 1962$), 4$ 49-62,

Rollins, Montgomery, "Convertible Bonds and Stocks," Annals

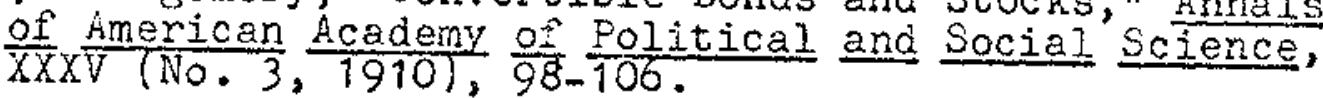

Stokes, Charles $G .$, "The Future of Variable Annuities," The Institutional Investor, I (March, 1967), 22-25, 50.

Schwartz, William, "Convertibles Get Realistic Image,"

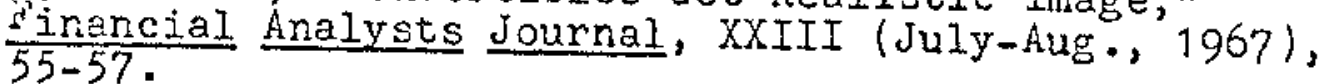

Seligman, Daniel and T. A. Wise; "New Forces in the Stock Market," Fortune, LXIX (Feb., 1964), 92-95, 194-206.

"The Power of Institutional Investors," Fortune, IXXII (Dec.,
$1965), 233,236,238$. 
"Two-Way Hedge, With Pitfal1," Business Week, CXV (Oct. 3, 1959), 1 15-16.

Welles, Chris, "The Unions: \$4 Billion Goes to Work," The

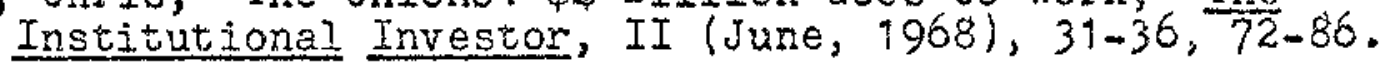

Wrightsman, Dwayne, "Pension Funds and Economic Concentration," The Quarteriy Review of Economics and Eusiress, VII Tinter, 1967), 29-36.

Reports and Manuals

Bladen, Ashby, Techniques for Investing in Convertible Bonds, New York, Salomon Brothers and hutzler, 1966.

Capital Adjustments, Volumes I and II of 1962, plus supplements updated to 1968, Englewood Cliffs, N. J., PrenticeHall, Ine.

Comprehensive Bond Values Tables, Boston, Financial Publishing Co., 1936 .

Convertible Fact Finder, New York, Kalb, Voorhis and Co., Dec. 12, 1966 .

Graphic Stocks, Vol, XX of 1964 and Vol. XXII of 1966, Newfoundland, N. J., F. W. Stephens Co.

Institute of Life Insurance, 1967 Life Insurance Fact Book, New York, Institute of Iife Insurance, 1967.

Investment Banker-Broker AImanac, $23 \mathrm{rd}$ annual ed., by the publishers of Finance magazine, New York, 1968.

Investment Bankers Association of America, IBA Corporate Financing Builetin, No. X. Washington, D. C., March,

Investor's Tax Kit, 1966-67 and 1967-68 editions, New York, Merrill Lynch, Pierce, Fenner and Smith, Inc.

Moody's Bank and Finance Manual, New York, Moody's Investors Service, Inc., 1963, 1967.

Moody's Bond Survey, Vol. 58 of 1966 and Vol. 60 of 1968, New York, Moody's Investors Service, Inc.

Moody's Industrial Manual, New York, Moody's Investors Service, Inc., 1963 through 1967. 
Moody's Public Utility Manual, New York, Moody's Investors Service, Inc., 1956, 1959, 1963, 1967.

Moody's Transnortation Manual, New York, Moody's Investors Service, Inc., 1961, 1963, 1964, 1967.

Standard and Pcor's Annual Dividend Record, New York, Standard and Poor's Corp., 1959 through 1967.

Standard and Poor's Trade and Securities Statistics; Security Price Index Record, New York, Standard and Poor's Corp., 1968.

Standard Bond Reports: Convertible Bonds, New York, Standard and Poor's Corp., 1963 through 1967.

Standard Iisted Stock Reports, Vol. 33, New York, Standard and Poor's Corp., 1966.

Stock Facto-Graph Manual, 51 st ed., New York, Financial World (Guenter Publishing Corp.), 1965.

The Convertible Bond Chart Book, New York, Kalb, Voorhis and Co., Dec., 1966 .

\section{Public Documents}

Boerd of Governors of the Federal Reserve System, Credit by Brokers, Dealers, and Members of National Securities Exchanges, Regulation I, As Amended Effective March 11, 1968, with supplements through June 8, 1968, Washington,

Securities and Exchange Commission, Compilation of Releases Dealing With Matters Arising Under the Securities Exchenge Act of 1934 and Investment Advisers Act of 1940 , Washington, Government Printing Office, March, 1968 .

Securities and Exchange Commission, Cost of Elotation, 19451949, Washington, Government Printing Office, Feb., 1951.

Securities and Exchange Commission, Cost of Flotation of Coroorate Securities, $1951-1955$, washington, Government Printing office, June, 1957 .

Securities and Exchange Commission, Privately-Placed Securities - Cost of Flotation, Government Printing Orsice, Sept. 2, $19 \overline{52}$. 
Securities and Exchange Commission, Statistical Bulletin,. Vol. XXVII, washington, Government Printing office, Feb., 1968, p. 17 .

$$
\begin{gathered}
\text { Speeches, Interviews, and Unpublished } \\
\text { Material }
\end{gathered}
$$

Bladen, Ashoy, "A Monetary Approach to the Convertible Bond Market," reprint of speech delivered in Philadelphia on Sept. 22, 1966, by Ashby Bladen of Salomon Brothers and Hutzler, New York.

Brown, Charles Clayton, "Convertible Bonds and the Cost of Capital: Some Theoretical Considerations and Empirical Findings," abstract of doctoral dissertation, University of Washington, 1966.

Cohen, Manuel F., Chairman, Securities and Exchange Commission, "Institutional Investment: Some Current Developments," reprint of address before the American Pension Conference, New York, May 28, 1968.

Letters from four underwriting firms located in New York, Chicago, and Philadelphia, July, 1968.

Reed, Norman and Fred Lynch, staff members, regional office of Securities and Exchange Commission, Fort Worth, Texas, interview, July $3,1968$.

Turner, John W., manager of underwriting department, Eppler, Guerin, and Turner, Inc., interview, Dallas, Texas, July $9,1968$.

\section{Newspapers}

"American Stock Exchange Bonds," The Wall Street Journal, XLII (July 15, 1968), 18 .

Bladen, Ashby, "Convertible Debentures: An Analyst Finds Many of Them on the Bargain Counter," Barron's, XLVIII (Jan. 8, 1968), 5 ff.

Cohen, Manuel F., "SEC to Investigate Institutional Investors," The Commercial and Financial Chronicle, CCVII (Feb. 29, "Effective SEC Registrations," Barron's XLVIII (Feb. 29,
1968), 906, 907 . 
"Federal Reserve Moves to Extend Its Margin Rule to Unregulated Ienders to Curb "Excessive Credit?," The WaII Street Journa], $X L$ (Oct. 23, 1967), $2 \mathrm{ff}$.

Hibbard, G. A., "Hedge in Convertibles, Such Bonds Have Their Points in Today's Uncertain Warkets," Barron's, XXXVIII (Feb. 17, 1958), 9, 10.

Homer, Sidney, "The Impact of Corporate Pension Funds on Equity and Bond Warkets," The Commercial and Financial Chronicle, CCV (Feb. 23, 1967), 793, 806, 807 .

Levy, G. L., "Arbitrage, Convertible Bonds and the Investor," The Commercial and Financial Chronicle, Vol. 194 Tuly 20, 1961), pp. 278, 279.

Margin Requirements for Listed Stocks Raised to $80 \%$ from $70 \%$ by Reserve Board, "Excessive Credit' Cited," The Wall Street Journal, XLI (June 10, 1968), 3.

"Markets in Other Cities," The Wall Street Journal, XIII (July 15, 1968), 19.

"Wew York Stock Exchange Bonds," The hall Street Journal, XLI (June 25, 1968), 21 .

Stern, Walter P., "Institutional Investors in the 'Performance' Market," The Commercial and Financial Chronicle, Vol. 206, (Nov. 23, 1907), pp. 1939, 1960.

"Tenneco, U. S. Finance's Convertible Issues Are Put Aside Due to Federal Reserve's Plan," The Wall Street Journal, XL (Oct. 24, 1967), 21.

"The Outlock: Appraisal of Current Trends in Eusiness and Finance," The thaI 1 Street Journal, XXXVIII (Nov.7, 1966), 1 .

The Wa11 Street Journal, XIII (July 17, 1968), "tombstone advertisement," p. 15.

The Wall Street Journal, North Texas State University microfilm files, Midwest editions January, 1956, through December, 1961; New York editions January, 1962, through April, 1968, plus original copies through August, 1968. 